\title{
POVOS DE TERRA E ÁGUA: A COMUNIDADE PESQUEIRA CANTO DO MANGUE, CANGUARETAMA (RN) - BRASIL
}

\author{
MÁRCIA REGINA DA SILVA
}

Dissertação apresentada à Escola Superior de Agricultura "Luiz de Queiroz", Universidade de São Paulo, para obtenção do título de Mestre em Ecologia de Agroecossistemas.

PIRACICABA

Estado de São Paulo - Brasil

Maio - 2004 


\section{POVOS DE TERRA E ÁGUA: A COMUNIDADE PESQUEIRA CANTO DO MANGUE, CANGUARETAMA (RN) - BRASIL}

\section{MÁRCIA REGINA DA SILVA}

Geógrafa

Orientador(a): Prof $f^{\mathrm{a}}$. Dr ${ }^{\mathrm{a}}$. MARIA ELISA DE PAULA EDUARDO GARAVELLO

Dissertação apresentada à Escola Superior de Agricultura “Luiz de Queiroz", Universidade de São Paulo, para obtenção do título de Mestre em Ecologia de Agroecossistemas.

P I R A C I C A B A

Estado de São Paulo - Brasil

Maio - 2004 


\section{Dados Internacionais de Catalogação na Publicação (CIP) DIVISÃO DE BIBLIOTECA E DOCUMENTAÇÃO - ESALQ/USP}

Silva, Márcia Regina

Povos de terra e água: a comunidade pesqueira Canto do Mangue, Canguaretama

(RN) - Brasil / Márcia Regina Silva. - - Piracicaba, 2004.

126 p. : il.

Dissertação (mestrado) - - Escola Superior de Agricultura Luiz de Queiroz, 2004.

Bibliografia.

1. Carcinocultura 2. Desenvolvimento sustentável 3. Ecologia humana 4. Ecossistemas c mangue 5. Impacto ambiental 6. Pesca artesanal 7. Proteção ambiental 8. Recursos pesqueiros I. Título

CDD 574.52636

\section{"Permitida a cópia total ou parcial deste documento, desde que citada a fonte - O autor"}


Aos meus irmãos Anchieta e José Raimundo, com carinho, por me ensinarem a importância de aceitar e conviver com as diferenças e as incertezas.

A Rosário Farias, minha mãe, pela força, dedicação e paciência de me ouvir nos momentos difíceis.

Com saudades, à memória do meu pai, Raimundo Claudino da Silva, e dos meus avós Nenzinha e Antônio Farias, cujas vidas permanecem inscritas na minha.

Com esperança, a Gabriela, Laize e Thyago, que ofuturo thes dê o direito de viver em um ambiente saudável.

Dedico. 


\section{AGRADECIMENTOS}

A DEUS, pelo cultivo dessa energia, cuja incontinência me dá força, me inspira e me impulsiona ao prazer de viver, conhecer e descobrir, mesmo diante das adversidades.

Aos pescadores e moradores do Canto Mangue, por me receberem e compartilharem comigo os seus saberes.

À profa. Maria Elisa Garavello, cuja orientação, aceitação, confiança, ensinamentos e condições de trabalho foram constantes, agradeço a oportunidade de compartilhar ao seu lado saberes e sonhos por eqüidade social no pleno sentido do termo.

À profa. Silvia Molina, por acompanhar meu trabalho do início ao fim, pelas contribuições precisas, ensinamentos e pelo cuidado que sempre demonstrou ter por mim, também por ter me indicado Maria Elisa como orientadora.

À profa. Conceição Almeida (UFRJ) agradeço a vinda á ESALQ, as contribuições e por me apresentar uma forma "complexa de 'ver a ciência'e 'de viver um estilo intelectual' em maior sintonia com as várias verdades que o mundo abriga".

Ao prof. Dalcio Caron, pelas longas conversas e troca de idéias, cujas contribuições foram inúmeras, e por acompanhá-lo na realização do Programa de Apoio ao Ensino.

À profa. Socorro Martim e ao prof. Fernando Moreira (UFRN), orientadores de todas as horas, agradeço a amizade, os acompanhamentos em todos as etapas do trabalho de campo, as dúvidas geográficas e estatísticas esclarecidas e a oportunidade de trabalhar junto a vocês.

Aos meus irmãos Carlos, Luiz e Antônio e às minhas irmãs Conceição, Maria Gorete e Martha: sem a ajuda de vocês a realização desta etapa acadêmica não seria possível! Agradeço sinceramente a oportunidade que me proporcionaram!

Ao amigo prof. Iran Abreu Mendes (UFRT), pelo incentivo e ajuda. A Luiz Antônio, Giany Aimone e Márcia Sartori agradeço os prestes e a força. 
A Dilson Melo agradeço a compreensão, o carinho, a atenção e a ajuda que me dispôs, encurtando os longos e áridos caminhos percorridos nas minhas idas e vindas $\mathcal{N}$ atal/Piracicaba.

À Nivia Dias, por me apresentar novos horizontes acadêmicos, e a Nildo Dias, por me receber em Piracicaba e ter me adotado como irmã, compartilhado comigo momentos felizes e tristes.

À Julia Martins, Milena Ramires e Renata Sartori, por dividirem as realizações e dificuldades da minha estada na ESALQ; também pelas contribuições acadêmicas e respeito às diferenças. Enfim, por terem sido como irmãs.

$\mathcal{A}$ todos os meus amigos do PPGIEA pela troca de experiência. Aos amigos da UFRN Josiel, Bernadete, Jailsa e Pavla, pela força, saberes e idéias compartilhadas. Aos amigos de convivência Maurício, Henrique, Fabiana, Vanessa, Ana Cláudia, Kátia e Raquel, pelo respeito e carinho.

À amiga Lucilene Dias, pela hospedagem durante o trabalho de campo, carinho e atenção.

Ao Programa de Pós-Graduação Interunidades em Ecologia de Agroecossistemas ESALQ/CENA/USP agradeço a oportunidade e o aprendizado.

Ao LES - Ciências Humanas e ao Laboratório de Ecogenética de Resíduos Agroindustriais e Ecologia Humana (ESALQ) agradeço os espaços de trabalho disponibilizados, nos quais escrevi a maior parte desta dissertação.

Ao Grupo de Estudos da Complexidade (GRECOM-UFRV), pelo acervo bibliográfico que me foi apresentado e disponibilizado.

Ao Departamento de Geografia (UFRN), pelo espaço gentilmente cedido, através das profa(s) Socorro Martim e Maria Francisca J. L. Ramalho, que me permitiu desenvolver parte deste trabalho.

Aos amigos e amigas conquistados em Piracicaba, Luiz, Cleide, Ednaldo, Francilene, Edson, Lázara e Maurício, pela amizade e confiança.

Por fim, agradeço a todos que de alguma forma me ajudaram na realização deste trabalho. 


\section{O PESCADOR E O VENTO}

Numa canoa de sol. A manhã me faz ao largo. À noite tiro meu peixe. Um pargo. Moreia Sete Dentadas. Cortantes como rocega Vento $\mathcal{N}$ ordeste, na volta me pega. Ostra da arrebentação me lanha a tábua do queixo, Crava dente, tira bife, na gengiva do ar - recife (...) Na Croa da Água Bela, com seu anzol de barbela, me fisga (...) Talagada de aguardente, com siri de tira-gosto, Tudo isso é bom encosto.

Sudeste, Vento aloprado. Desarruma qualquer rota. Dá nó na barba do mar, entorta vôo de gaivota. Vento ruim, bandoleiro (...) de terra e costa (...) Dispara bala de vento.

O tiro 6ate no ar, ricocheteia na lua, no relento se dissolve. $\mathcal{N a}$ Ponta da Pedra Lisa, já de porre, vira brisa, assovia lento, morre. Numa rede de cem braças, velha e suja (...) Debaixo do cajueiro como qualquer um de nós se enterra o Vento na praia.

Barra de Cunhaú, Canguaretama - RNN, janeiro de 1976. Homero Homem de Siqueira Cavalcanti 


\section{SUMÁRIO}

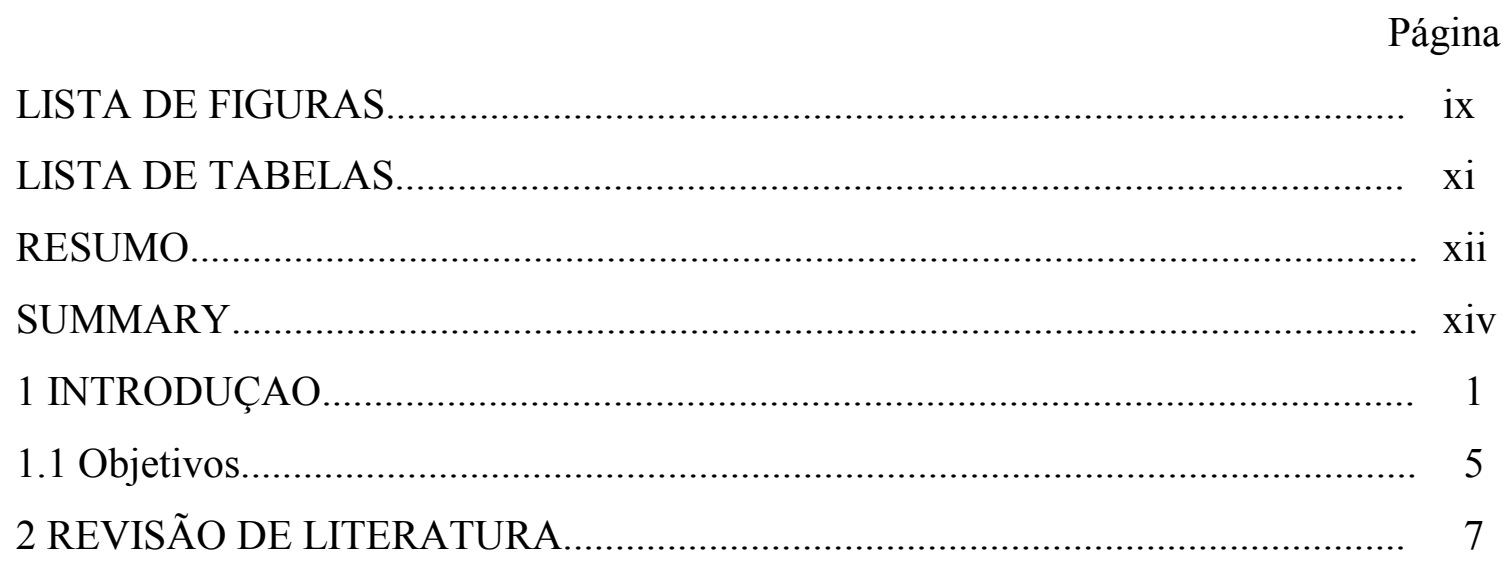

2.1 A idéia de desenvolvimento sustentável.......................................................... 7

2.2 A problemática ambiental e os desafios da sustentabilidade............................... 10

2.3 Saberes da tradição: um outro olhar............................................................. 14

2.4 Pescadores artesanais: saberes e práticas aplicadas ao uso dos recursos

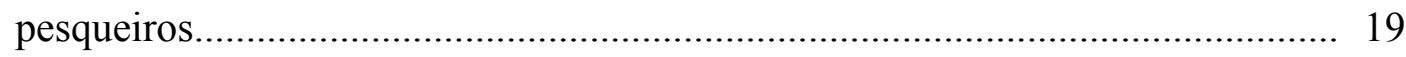

2.5 Carcinicultura: contexto local e global............................................................ 23

2.6 Importância dos manguezais........................................................................... 33

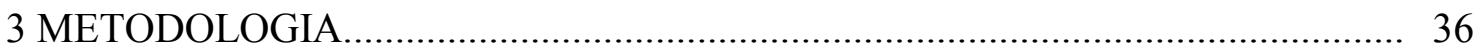

3.1 Abordagens da pesquisa............................................................................... 37

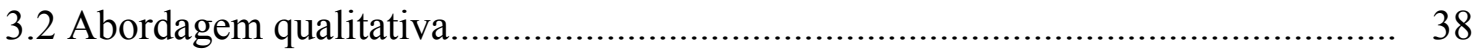

3.3 Abordagem quantitativa............................................................................. 44

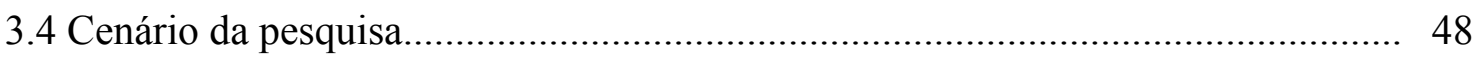

4 RESULTADOS E DISCUSSÕES................................................................ 53 
4.1 As metamorfoses ocorridas no uso do território e dos recursos......................... 53

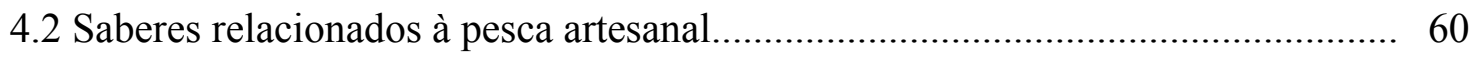

$4.3 \mathrm{O}$ modo de vida no espaço local................................................................ 74

4.4 As relações sociais no Canto do Mangue.......................................................... 88

4.5 Conflitos e benefícios decorrentes da carcinicultura...................................... 98

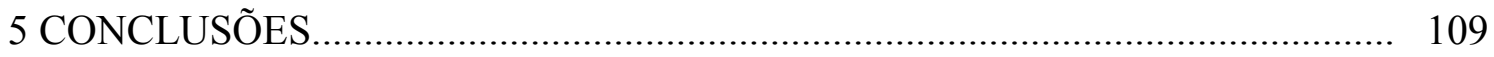

REFERÊNCIAS BILIOGRÁFICAS............................................................... 111 


\section{LISTA DE FIGURAS}

Página

1 Rio Grande do Norte: localização do município de Canguaretema.......................... 6

2 Principais estuários de cultivo de camarão marinho no Rio Grande do Norte....... 24

3 Tanque de camarão instalado no Canto do Mangue, fev., 2003 .............................. 24

4 Tanques de larvas...................................................................................... 32

5 Fertilização dos tanques de produção..................................................................... 32

6 Processamento do camarão......................................................................... 32

7 Tanques de cultivo no estuário do Curimataú/Cunhaú............................................. 35

8 Sr. Quinca, pescador e Tonha, marisqueira, fev., 2003 ......................................... 43

9 Vista do Pituasse, Canto do Mangue, fev., 2004 .................................................... 57

10 Tanques instalados no Pituassu, fev., 2004 ........................................................ 58

11 Pescador confeccionando tarrafa, fev.,2003 .................................................... 60

12 Distribuição dos tipos de embarcações em percentagem (\%), utilizadas em

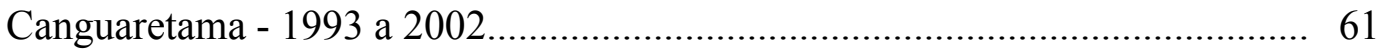

13 Estuário do rio Curimataú/Cunhaú, fev., 2003 .................................................. 64

14 Estuário do rio Curimataú/Cunhaú, com vista para o manguezal, fev., 2003....... 65

15 Contribuição média por espécie em Canguaretama de 1993 a 2002.................... 68

16 Lixão formado nas proximidades do Canto do Mangue, fev., 2004 ..................... 75

17 Canto do Mangue - vista da Rua do Quadro, fev., 2003 ...................................... 75

18 Moradora do Canto do Mangue aguardando a construção da sua casa, jan.,

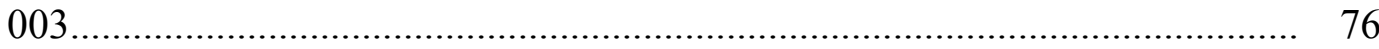

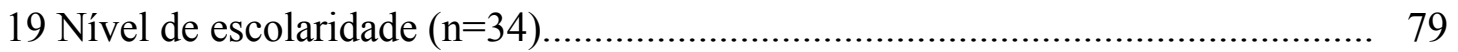

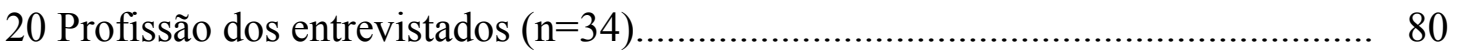




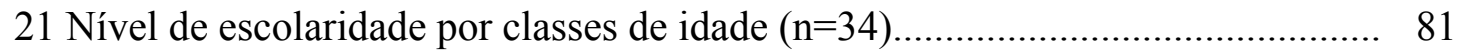

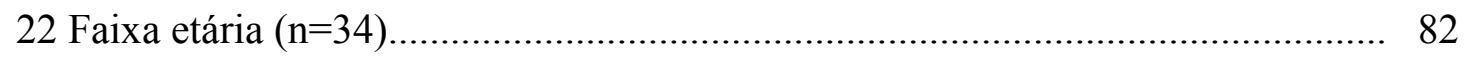

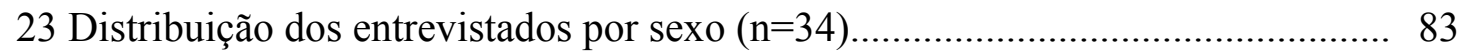

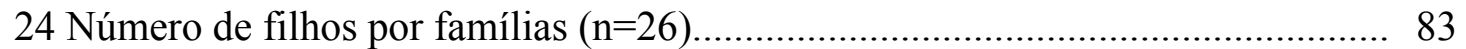

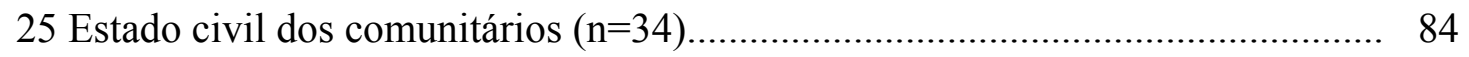

26 Criança ajudando no manuseio dos apetrechos de pescaria, fev., 2003.............. 88

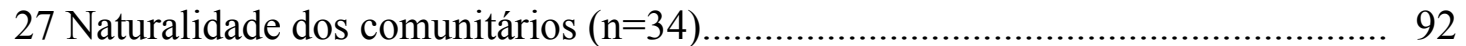

28 Comportamento da produção anual de pescado em Canguaretama de 1993 a

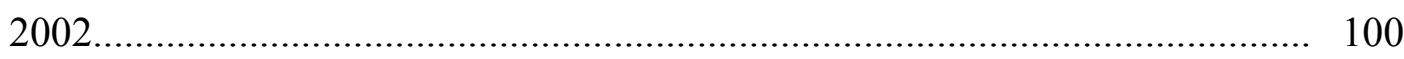

29 Comportamento da produção anual de caranguejos em Canguaretama de 1993

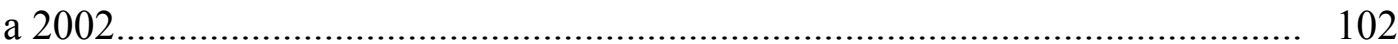




\section{LISTA DE TABELAS}

Página

1 Tipos de impactos relacionados a carcinicultura.......................................... 30

2 Classificação de Pearson............................................................................... 47

3 Espécies capturadas na comunidade Canto do Mangue.................................. 67 


\title{
POVOS DE TERRA E ÁGUA: A COMUNIDADE PESQUEIRA CANTO DO MANGUE, CANGUARETAMA (RN) - BRASIL
}

\author{
Autora: MÁRCIA REGINA DA SIVA \\ Orientadora: Prof ${ }^{a}$ MARIA ELISA DE PAULA EDUARDO GARAVELLO
}

\section{RESUMO}

Esta dissertação tem o objetivo de analisar as mudanças ocorridas nas condições de vida da população humana, na comunidade Canto do Mangue em Canguaretama $(\mathrm{RN})$, e as possíveis relações com a introdução da carcinicultura a partir de 1980. Foram utilizadas técnicas de pesquisa qualitativa (análise documental, entrevistas e observações in loco) e quantitativa (análise de tendência central, dispersão e correlação). Constatou-se que as alterações ocorridas no espaço local estão associadas às pressões ocasionadas por fatores de ordens externa e interna, como a implantação e expansão dos projetos de carcinicultura, que levaram ao avanço da especulação imobiliária e intensificaram o desmatamento das áreas de manguezais ao longo do estuário do rio Curimataú/Cunhaú, contribuindo para o abandono da agricultura de subsistência nessa comunidade, além de estar levando também ao abandono da pesca artesanal, por conseguinte, a perda dos saberes da tradição aplicados na realização dessa atividade. Verificou-se, ainda, que as alterações no uso do território e dos recursos ameaçam a biodiversidade e têm contribuído para a redução dos estoques pesqueiros do município de Canguaretama e, conseqüentemente, do Canto do Mangue, sobretudo o 
estoque de caranguejo-uçá (Ucides cardatus). Os resultados obtidos permitiram concluir que a produção em larga escala numa economia de mercado, como se constitui a carcinicultura, desconsidera a busca de equilíbrio nas configurações territoriais. Assim, as perturbações ambientais decorrentes da carcinicultura têm conseqüências de dimensões sócio-culturais, afetando diretamente o modo de vida dos moradores do Canto do Mangue. As empresas de camarão têm absorvido parte dos pescadores que estão deixando a atividade pesqueira. No entanto, o baixo nível de escolaridade associado à idade são fatores que deixam muitos deles fora do quadro de funcionários dessas empresas. Portanto, há necessidade de se criar condições que possibilitem o desenvolvimento da carcinicultura sem colocar em risco a sustentabilidade da região. 


\title{
PEOPLES OF LAND AND WATER: THE FISHING COMMUNITY CANTO DO MANGUE, CANGUARETAMA (RN) - BRAZIL
}

\author{
Author: MÁRCIA REGINA DA SILVA \\ Adviser: PROFa ${ }^{\mathrm{a}}$ MARIA ELISA DE PAULA EDUARDO GARAVELLO
}

\section{SUMMARY}

The objective of this research was to analyze the changes occurred in the conditions of life in the human population, at community Canto do Mangue in Canguaretama $(\mathrm{RN})$, and also their possible relationships with the introduction of the shrimp creation in captivity after 1980. Techniques of qualitative research were used (documentary analysis, interviews and observation in locus ) and quantitative (analysis of central trend, dispersion and correlation). It was evidenced that the occurred alterations in the local space are associated to the pressures caused by factors of external and internal order, such as implantation and expansion of the creation of shrimp in captivity projects. This led to the advance of the real estate speculation and intensified the deforestation of mangroves areas at the estuary of the river Curimataú/Cunhaú. It contributed to the abandon of the agriculture of subsistence in this community, as well as of handcraft fishing activity. Consequently, there was a loss of knowing traditional in the accomplishment of this activity. It was still verified that alterations in the use of territory and the resources threaten biodiversity and have contributed to the reduction of fishing supplies boats of the community of Canguaretama and consequently, the decrease of the quantity of shrimp (Ucides cardatus) at Canto do Mangue. The results 
allowed to conclude that the production in wide scale inside market economy, it disrespects the search of balance in the territorial configurations. Thus, the environmental disturbances caused by the shrimp creation of in captivity have social and cultural consequences, affecting directly the way of life of the Canto do Mangue inhabitants. The shrimp companies have employed part of the fishermen that are leaving the fishing activities, however the low level of scholarship and old age are factors that leave them out of team of employees of these companies. Therefore, conditions should be created to make possible to conciliate the shrimp creation in captivity and sustentability of the region. 


\title{
1 INTRODUÇÃO
}

\section{Apresentação}

\author{
"Ecossistema sui generis, nem terra \\ nem mar; de águas nem doces nem salgada; \\ nem floresta, nem campo, nem águas abertas; \\ nada disso parcelado, mas tudo ao mesmo \\ tempo".
}

Marta Vannucci

Meu primeiro contato com o universo da pesca foi há muito tempo. Ainda criança, em 1980 conheci de perto a dinâmica dessa atividade no município de Canguaretama $(\mathrm{RN})$, onde tive a oportunidade de estabelecer estreitos contatos com famílias de pescadores e participar do cotidiano das relações sociais daquela sociedade.

Dessa forma, identifico-me com as palavras de Josué de Castro, no romance Homens e caranguejos, quando menciona "a primeira sociedade com que travei conhecimento foi a sociedade dos caranguejos. Depois, a dos homens habitantes dos mangues, irmãos de leite dos caranguejos. Só muito depois é que vim a conhecer a outra sociedade, a dos homens - a grande sociedade" (2001, p. 13).

Acredito que esse contato com os "homens dos mangues e do mar" me permitiu participar de momentos especiais, como o preparo para a ida ao mar; a espera das mulheres por seus esposos; a chegada ao porto; o desembarque do pescado e a venda aos atravessadores. Além disso, as festas comemorativas dessa população humana, suas lendas e crenças construíram no meu imaginário infanto-juvenil importantes imagens e referências para a vida.

O homem do mangue e do mar foi um tema sempre presente que me aproximou do mágico universo da pesca e me rendeu um respeito considerável pela natureza. Esse 
contato, desde logo, com a sociedade dos trabalhadores dos mangues e do mar me aproximou do modo de vida dessa população.

De forma acadêmica, a minha relação com o universo da pesca se deu durante a participação em um projeto realizado no litoral do Rio Grande do Norte, no período de 1999 a 2001, como aluna de iniciação científica do Departamento de Geografia da Universidade Federal do Rio Grande do Norte. Esse trabalho me concedeu a oportunidade de estabelecer novos contatos com pescadores, desta vez na Praia de Muriú $(\mathrm{RN})$. A realização de entrevistas com pescadores da referida praia mostrou-me a existência de elementos culturais que se assemelhavam aos dos pescadores de Canguaretama. Foi a partir desses contatos, e do forte traço cultural que me unia à sociedade pesqueira, que surgiu a idéia de desenvolver uma pesquisa junto aos pescadores artesanais desse município.

A idéia permaneceu, mas as oportunidades eram restritas até que, em uma aula de campo realizada na graduação, visitei o distrito de Barra de Cunhaú em Canguaretama. O enfoque da aula estava voltado para a criação de camarão em cativeiro, ou seja, a carcinicultura.

Muito me chamaram atenção os problemas sócio-ambientais desencadeados a partir da carcinicultura. Diversas reportagens circulavam na mídia envolvendo, principalmente, três atores sociais: os empresários do ramo, os órgãos responsáveis pelo cumprimento das leis ambientais e a população local. Em relação a essa última, o foco da discussão voltava-se, especialmente, para as alterações no modo de vida dos moradores, que dependem da pesca para a sua sobrevivência e para a questão ambiental.

$\mathrm{O}$ fato de a pesca artesanal, uma tradição do município, estar enfrentando pressões que atingem diretamente a vida dos pescadores despertou o meu interesse em trabalhar na área. Nas minhas lembranças de tempos atrás, os pescadores passavam as tardes fazendo redes e "prosando" sobre os seus conhecimentos e os acontecimentos do universo pesqueiro.

Assim, essas lembranças e inquietações despertaram-me para a realização desta pesquisa. Espero que as informações que ora disponibilizo sirvam de reflexão e contribuição para as discussões ambientais e o reconhecimento do saber tradicional 
aplicado à pesca artesanal, conduzindo a ações locais de manejo e conservação dos ecossistemas aquáticos e correlatos, dentro da premissa de sustentabilidade.

\section{Importância da pesquisa}

O Rio Grande do Norte possui um litoral de $399 \mathrm{~km}$ de extensão, onde estão localizados 25 municípios costeiros e 83 comunidades pesqueiras, de acordo com o Centro de Pesquisa e Gestão de Recursos Pesqueiros do Litoral do Nordeste - CEPENE (2001). Essas comunidades se encontram em intenso processo de transformação espacial e acelerado processo de urbanização, em virtude de atividades econômicas introduzidas nas cidades litorâneas do Estado, como o turismo e a carcinicultura.

O município de Canguaretama foi um dos pioneiros na experiência da carcinicultura no âmbito estadual, devido às favoráveis condições físico-ambientais; já no início de 1980 a carcinicultura passou a ser implantada. Atualmente se constitui em uma das principais atividades econômicas do município e do Estado.

A área onde se encontram instaladas as fazendas de camarão, precisamente o estuário do rio Curimataú/Cunhaú e seu entorno, dispõe de uma reserva de manguezais considerável. Esse ecossistema apresenta-se em intenso processo de degradação, inicialmente devido à atividade salineira, cuja decadência se deu a partir de 1968, e nos dias atuais pela ampliação da carcinicultura, entre outros fatores.

Em Canguaretama, como em diferentes regiões do mundo, os manguezais foram e ainda são fontes de alimentos e de renda, de uso comum para os pescadores artesanais, visto que essa população humana mantém um contato direto com o seu meio ecológico e dispõe de um profundo conhecimento em relação ao manejo e conservação dos ecossistemas aquáticos.

No Canto do Mangue, comunidade pesqueira localizada em Canguaretama e unidade empírica de referência desta dissertação, os pescadores artesanais enfrentam problemas sócio-culturais, econômicos e ambientais decorrentes das modificações ocorridas no espaço-tempo que aceleram a dinâmica do modo de vida dos moradores. 
As mudanças estão associadas às pressões ocasionadas por fatores de ordem externa e interna que acabam também alterando a dinâmica local, como implantação de novas atividades econômicas; avanço da especulação imobiliária; desmatamento da área de manguezal e o abandono da atividade pesqueira. As alterações do ecossistema contribuem para modificar a vida dos moradores da comunidade e, conseqüentemente, para a perda do conhecimento local associado às práticas econômicas anteriores.

É certo que, ao longo dos tempos, as comunidades pesqueiras acumularam uma vasta experiência empírica. Esses saberes são transmitidos aos membros dos grupos por meio de ensinamentos práticos. Daí a necessidade de se criar condições que possibilitem o desenvolvimento econômico levando em consideração, acima de tudo, a identidade cultural das populações tradicionais, bem como alternativas de manejo e conservação dos recursos de forma que atendam às necessidades dessas populações.

Logo, os argumentos mencionados indicam a necessidade da realização de estudos na área em questão, com a finalidade de contribuir para a valorização e a sobrevivência sócio-cultural, econômica e ambiental das comunidades pesqueiras, assim como pesquisas que visem resultados conciliatórios entre o cultivo do camarão e a sustentabilidade da região.

A partir dos resultados deste trabalho será possível se obter um diagnóstico das condições sócio-econômicas da população, bem como identificar aspectos gerais das implicações ambientais decorrentes da carcinicultura nessa área, sendo ainda possível ampliar de forma mais generalizada estas constatações para outras comunidades pesqueiras, que se encontram sob as condições de ocupação e apropriação dos seus territórios por grandes corporações econômicas; isto é claro, considerando as singularidades e pluralidades inerentes a essas populações humanas e as suas interações com o ambiente. 


\subsection{Objetivos}

Esta dissertação tem por objetivo geral analisar as mudanças ocorridas nas condições de vida da população humana, na comunidade Canto do Mangue em Canguaretama $(\mathrm{RN})$, e as possíveis relações com a introdução da carcinicultura a partir de 1980 .

Os objetivos específicos podem ser assim descritos: 1. analisar as modificações ocorridas no uso do território e dos recursos a partir de 1980; 2. verificar saberes tradicionais dos pescadores, relativos aos aspectos ecológicos, sobre os métodos e locais de captura, diversidade e reprodução de espécies; 3. identificar o perfil da comunidade; 4. analisar o modo de vida (condições de moradia, hábitos alimentares, e atividades econômicas que complementam a pesca); 5. analisar as relações sociais (divisão do trabalho, relações de parentesco e o funcionamento da Colônia de Pescadores); 6. identificar os conflitos decorrentes da carcinicultura na comunidade; 7. analisar o comportamento e o grau de correlação entre a produção de caranguejo e a produção de camarão em cativeiro no período de 1993 a 2002.

Para tal propósito, o trabalho está estruturado em três capítulos, além da introdução e das conclusões, os quais sistematizam as constatações da pesquisa empírica e teórica.

O primeiro capítulo aborda o referencial teórico que fundamenta a dissertação. Este apoia-se na premissa de desenvolvimento sustentável, sustentabilidade, na concepção dos saberes da tradição e no uso e manejo dos recursos pesqueiros por populações humanas. Apresenta ainda, um breve histórico da carcinicultura no município de Canguaretama e no Rio Grande do Norte, tecendo considerações sobre aspectos relativos aos possíveis impactos sócio-ambientais dessa atividade e abordando a importância dos manguezais.

O segundo apresenta considerações sobre $\mathrm{o}$ método $\mathrm{e}$ as abordagens empregados na realização desta pesquisa; e adentra-se no processo metodológico que norteou o estudo. 
O terceiro capítulo apresenta os resultados da pesquisa de campo e documental e as discussões a respeito das implicações referentes às mudanças ocorridas nas condições de vida dos moradores do Canto do Mangue.

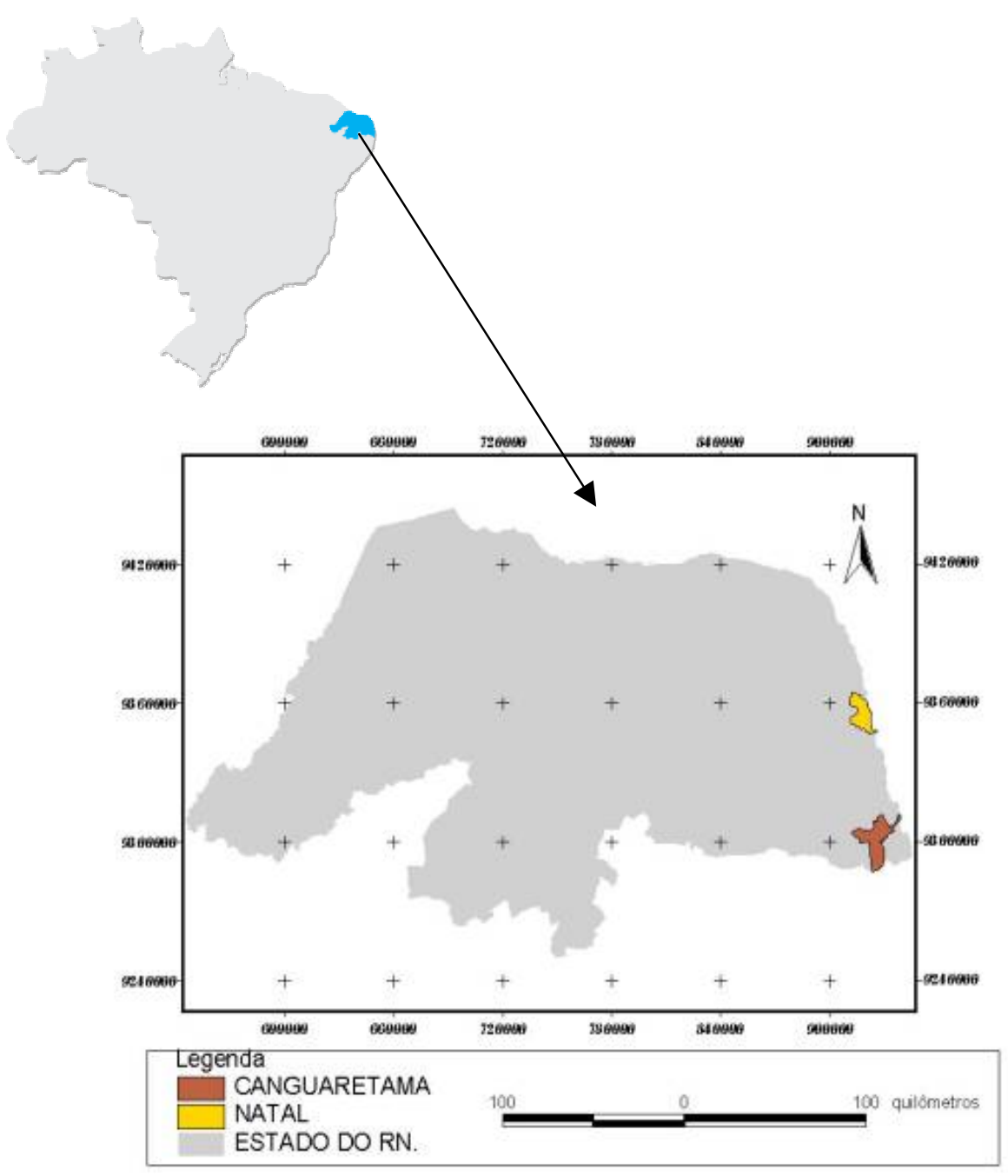

Figura 1-Rio Grande do Norte: localização do município de Canguaretema

Fonte: Departamento de Geologia, Universidade Federal do Rio Grande do Norte - UFRN, 2004. (Adaptado) 


\section{REVISÃO DE LITERATURA}

\subsection{A idéia de desenvolvimento sustentável}

O futuro tem vários nomes. Para os fracos, é o inatingível. Para os medrosos, o desconhecido. Para os corajosos, a chance.

Victor Hugo

A partir do fim da Segunda Guerra Mundial (1945), o conceito de desenvolvimento econômico passou a ser utilizado num contexto de formação de instituições mundiais, de harmonização de interesses e de práticas econômicas, bem como de uma teoria econômica que depositava na ação regulatória do Estado a possibilidade de manutenção de taxas de crescimento mais elevadas. Esse conceito fundamentou uma ideologia altamente otimista que previa o crescimento econômico contínuo, visto como um processo de utilização cada vez mais intensivo de capital, de redução do uso de mão-de-obra e de utilização intensa dos recursos naturais (Caporali, 1995).

Essa teoria econômica ocupou amplo espaço institucional, dominando ideologicamente a economia e a política tanto nos setores conservadores como naqueles que se situavam mais à esquerda. Tal quadro manteve-se praticamente inalterado do final da Segunda Guerra Mundial até o início da década de 1970. Nesse contexto, os avanços teóricos realizados no campo da economia concentraram-se nos instrumentos de gerenciamento dos níveis de atividade econômica por parte dos governos. 
No entanto, a forma pela qual tal teoria econômica enfrentava os problemas de ordem ambiental começou a ser criticada por estudiosos que têm por referência o equilíbrio ambiental e a temática da natureza. Em 1969, um grupo de cientistas de alto prestígio assinou um manifesto que criticava o desequilíbrio entre o desenvolvimento econômico e a dinâmica ambiental. Seu título, Blueprints for survival, chamava a atenção para o fato de que o futuro da humanidade estava ameaçado (Brüseke, 1995).

Pouco depois, uma organização não-governamental, o Clube de Roma, contratou uma equipe de cientistas que elaborou um estudo sobre Os limites do crescimento, mostrando a crise ambiental gerada por processos cumulativos e sinergéticos do crescimento econômico e populacional, da mudança tecnológica e da exploração dos recursos. Vale ressaltar que esse trabalho sofreu muitas críticas, sobretudo pelo tom apocalíptico como foram tratadas as questões estudadas (Leff, 1999).

A preocupação ambiental crescente desencadeou a Conferência de Estocolmo em 1972 e adquiriu adeptos de diferentes setores do conhecimento, preocupados em assegurar a melhoria da qualidade de vida na Terra. Em 1987, a Comissão Mundial do Meio Ambiente da Organização das Nações Unidas - ONU publicou um documento sobre a relação desenvolvimento/meio ambiente e as perspectivas do planeta face aos dilemas desse binômio.

O documento intitulado Relatório Brundtland (Nosso Futuro Comum) alertava para a necessidade das nações se unirem na busca de alternativas aos rumos da expansão econômica vigente, de modo a se evitar a degradação ambiental e social planetária. Destacava também que crescimento econômico sem melhoria da qualidade de vida das sociedades não poderia ser considerado um fator positivo. No entanto, o relatório reconheceu ser possível às nações alcançarem altos níveis de crescimento econômico sem destruir os recursos naturais, conciliando desenvolvimento econômico e conservação ambiental, o chamado desenvolvimento sustentável (ONU, 1991).

Para o Relatório Brundtland, desenvolvimento sustentável é "aquele que atende às necessidades do presente sem comprometer a possibilidade de as gerações futuras atenderem a suas próprias necessidades" (ONU, 1991, p. 46). O referido relatório transmitiu ainda o desejo de uma mudança paradigmática de modo a construir um estilo 
de expansão econômica que não se mostrasse excludente socialmente e danosa ao ambiente.

De acordo com Brüseke (1995), o documento apresenta um grau elevado de realismo. Mas ele toca com cuidado nos interesses das nações industrializadas, mantendo um tom diplomático na redação, provavelmente uma das causas da sua grande aceitação depois de ser publicado.

O desenvolvimento sustentável tem uma conotação bastante positiva para instituições internacionais, como o Banco Mundial, Organização das Nações Unidas para Educação, a Ciência, e a Cultura - UNESCO e outras entidades que o adotaram para marcar uma "nova filosofia" do desenvolvimento econômico. A nova visão pretende combinar eficiência econômica com justiça social e prudência ecológica. Podese ressaltar que esse tripé virou regra indispensável nas solicitações de verbas para projetos no campo social, ecológico e econômico dos países africanos, asiáticos e latinoamericanos (Dani, 1994).

Já na década de 1990, a Agenda 21, provavelmente o mais importante resultado da Conferência das Nações Unidas sobre Meio Ambiente e Desenvolvimento - 1992, realizada no Rio de Janeiro, Brasil, contribuiu para cristalizar a essência da premissa de sustentabilidade.

Para ocorrer um desenvolvimento sustentável, a observância do princípio de sustentabilidade é um requisito elementar. Essa diz respeito a um esforço para buscar a durabilidade, a constância e as justas proporções de qualidade dos diversos potenciais da natureza, sendo considerados dois aspectos fundamentais nas estratégias dessa forma de crescimento econômico: o aumento demográfico sustentado e o desenvolvimento técnico-científico (Dani, op. cit.).

Portanto, o conceito de sustentabilidade comporta múltiplas dimensões: sustentabilidade social, ecológica e ambiental, territorial, econômica, política e cultural. Isso significa que não se pode compreender o desenvolvimento sustentável sem levar em consideração as dimensões da sustentabilidade. Faz-se necessário, então, ao se definir os objetivos do desenvolvimento econômico e social, levar em consideração a premissa de 
sustentabilidade em todos os níveis e em todos os países do mundo, seja nos "centrais" ou nos chamados "periféricos” (Leff, 2001; 2000 e Saches, 1998).

Não se tem a pretensão de entrar no mérito das discussões teóricas do desenvolvimento sustentável, cujo emprego neste trabalho é realizado com base nas formulações e reflexões de autores como Sachs (1998a, 1998b, 1986) e Leff (2001a, 2001b, 2000, 1999, 1994). Esses autores se dedicam ao estudo do tema ora tratado e criticam a forma pela qual ele vem sendo apropriado e aplicado no âmbito das políticas econômicas vigentes, questionam as possibilidades do desenvolvimento sustentável, tomando-o no seu sentido pleno, numa economia de mercado. Para tais autores, desenvolvimento sustentável significa desenvolvimento social e econômico estável; equilibrado com mecanismos de distribuição das riquezas geradas, com capacidade de considerar a fragilidade, a interdependência e as escalas de tempo próprias e específicas dos elementos naturais.

\subsection{A problemática ambiental e os desafios da sustentabilidade}

“A consciência ecológica, isto é, a consciência de habitar, com todos os seres mortais, a mesma esfera viva (biosfera): reconhecer nossa união consubstancial com a biosfera conduz ao abandono do sonho prometéico do domínio do universo para nutrir a aspiração de convivibilidade sobre a Terra”.

Edgar Morin

A atual conjuntura mundial em termos ecológicos, sociais, culturais e econômicos nos aconselha a raciocinar de forma global, articulando as soluções imediatas e as metas de transcender as fronteiras estritamente locais e nacionais. Essas constatações permanecem válidas mesmo que o realismo político nos leve a pensar que, no decorrer dos próximos decênios, os Estados-Nação terão ainda um papel relevante a desempenhar, funcionando como escudos protetores contra os efeitos negativos do 
processo de globalização, ainda insuficientemente controlados por meio de acordos internacionais. Em todo caso, o problema da gestão dos patrimônios comuns da humanidade - naturais e culturais - emerge atualmente como um desafio de primeira grandeza (Sachs, 1998a).

Observa-se atualmente que os problemas ambientais se colocam num quadro global (europeu, asiático, africano ou latino-americano) e ultrapassam as fronteiras políticas, étnicas e econômicas, atingindo todos os continentes e nações do planeta. Pode-se então dizer que os problemas ambientais mundiais agem em escala local que, por sua vez, retroage em escala global. Para dar respostas ao desafio de entendimento e solução dos problemas ambientais é preciso contextualizá-lo no local e visualizá-lo em âmbito mundial. Tratar os problemas ambientais de forma isolada se constitui num equívoco, pois nesta época de "mundialização" as aflições das populações humanas tornam-se transversais, multidimensionais e planetárias (Morin, 2000 e Morin \& Kern, 2001).

Contra a possibilidade de destruição da natureza os movimentos ecológicos propõem uma ampla variedade de alternativas, que vão desde a imposição de limites ao desenvolvimento capitalista até a rejeição da própria idéia de desenvolvimento econômico e a adoção de estratégias antidesenvolvimentistas, baseadas na subsistência, no respeito à natureza e na produção tradicional (Santos, 2003 e Santos \& Rodrigues, 2002).

Sob a perspectiva da teoria dos sistemas, a sustentabilidade é a força motriz fundamental do desenvolvimento de todo sistema aberto, auto-organizado e capaz de evoluir (Morin \& Kern, 2001). Todos os sistemas abertos precisam importar energia e matéria em quantidade e com a qualidade adequada, e exportar energia e matéria desvalorizadas para poder garantir sua reprodução.

Esse raciocínio é aplicado à sociedade atual, em pleno processo de globalização e integração sócio-econômica, na qual o uso dos recursos naturais alimenta o "desenvolvimento econômico", produzindo um nível preocupante de injustiça social e transtornos ambientais ao longo processo produtivo. 
A percepção dos limites no uso dos recursos traz conseqüências profundas na maneira de encarar o futuro da humanidade, levando a questionamentos importantes. Nossa forma de desenvolvimento garante projeção de futuro? A resposta é complexa porque, para se entender a crise ambiental causada, sobretudo, pelo atual modelo de desenvolvimento econômico, é preciso fazer uso de diferentes ramos das ciências, estabelecer um diálogo entre as disciplinas no sentido de buscar um entendimento e apontar possíveis soluções (Morin, 2000). Afinal conforme a expressão de Prigogine (2001, p. 100) "a ciência é um diálogo entre o homem e a natureza".

Nesse contexto, surgem novas propostas de reflexão sobre a nossa realidade sócio-econômica, incluindo o modo de produção, o mercado e a relação da sociedade com a natureza. Tais reflexões têm-se desenvolvido no sentido de integrar os conhecimentos das ciências tradicionais numa teoria mais ampla de sistemas abertos, com o objetivo de criar parâmetros e indicadores capazes de produzir uma imagem integrada do processo sócio-econômico e ambiental atual. Essas propostas buscam respostas mais abrangentes e mais transparentes porque a procura de riquezas e de poder por parte das minorias não pode servir de justificativa para o massacre social e cultural de milhões de seres humanos, nem para a voracidade crescente com a qual os recursos naturais necessários à reprodução da vida estão sendo destruídos (Fenzl, 1998).

A definição de desenvolvimento sustentável aponta para a premissa de sustentabilidade como primeiro passo para uma nova forma de pensar, reconhecendo um princípio da ética do desenvolvimento, "exigindo autocontrole dos recursos potencialmente escassos e de ecossistemas delicados que podem, certamente, ser bem manejados para benefício da humanidade, mas que requerem uma gestão cuidadosa e ambientalmente sã” (Sachs, 1986, p. 139).

Para Santos \& Rodríguez (2002), é preciso criar formas alternativas de produção que valorizem o caráter coletivo do desenvolvimento de baixo para cima, gerando um processo de construção de poder comunitário, alcançando o potencial para os efeitos das iniciativas econômicas populares atingindo a esfera política e gerando um vínculo virtuoso, contrariando as causas estruturais da marginalização, privilegiando a escala local, tanto como objeto de reflexão como de ação social. 
Os desafios da sustentabilidade são perpassados também por dificuldades de inclusão econômica e social das comunidades esquecidas pela dinâmica do capital no mercado mundial. Acima de tudo, passam pelo reconhecimento da necessidade de considerar que, no último século, observou-se um estilo de desenvolvimento ecologicamente predatório, socialmente perverso e politicamente injusto (Leff, 2000).

$\mathrm{O}$ estudo das práticas produtivas das culturas tradicionais aparece como um recurso na construção de padrões tecnológicos mais adequados para o desenvolvimento do potencial produtivo dos ecossistemas. Essas práticas dependem de processos simbólicos e de significação cultural, que estabelecem as formas nas quais elas se articulam com as cosmovisões, os mitos e as crenças religiosas de cada comunidade (ibid.).

Por sua vez, os processos simbólicos determinam as formas técnicas, os ritmos e a intensidade da transformação da natureza, seus padrões de consumo e o acesso socialmente sancionado aos seus recursos. Assim, os conhecimentos tradicionais dos povos geram práticas de manejo sustentável de recursos, através de certos estilos culturais de organização produtiva (ibid.).

Ressalta-se a importância de investigar a organização social e produtiva das culturas tradicionais, em especial das sociedades ligadas à natureza, para conhecer o processo histórico de assimilação cultural, as transformações que sofreu o ambiente, assim como os traços culturais fundamentais que constituem a relação homem-ambiente nas comunidades tradicionais. Isso permite descobrir a racionalidade de suas práticas de uso dos recursos e reorientá-las para os objetivos da sustentabilidade (Leff, 2001b).

Assim, a dimensão sócio-antropológica é fundamental para entender a importância dos códigos da linguagem e das relações de parentesco na racionalidade das práticas simbólicas e produtivas das comunidades.

Em suma, a complexidade dos processos históricos das populações tradicionais e a análise das formas concretas pelas quais as diferentes formações culturais se apropriam do ambiente requerem um diálogo entre a antropologia e as demais ciências que se dedicam ao estudo ambiental para especificar os processos que conformam os estilos tradicionais de manejo e usufruto de seus recursos naturais, assim como sua 
organização produtiva e as modalidades técnicas que assumem o processo de transformação de seu ambiente.

\title{
2.3 Saberes da tradição: um outro olhar
}

\author{
"Sou filho de um pescador que \\ trabalha nas ondas do mar. Todo dia papai \\ me dizia: meu filhinho aprenda a remar, a \\ remar, a remar, a nadar, a nadar".
}

Cantiga de niná - Canto do Mangue. Autor anônimo.

A história da nossa espécie, vale dizer, do passado de cada um de nós, desencadeou-se por diversos caminhos possíveis, seguiu a reta da especialização e é, ao mesmo tempo, uma história de ganhos e perdas. Mais que isso, o caminho percorrido até hoje só foi possível às custas de redução, assimilação e negação de diversas formas de intercâmbio do homem com a natureza através do conhecimento (ALMEIDA, 2001a).

"O saber tradicional produziu, ao longo de sua história, um rico e diversificado marco de leitura e interpretação do mundo. A cultura que recebemos como herança fundamenta-se na divisão de dois domínios de saberes: de um lado a ciência, do outro a tradição. A hegemonia de um domínio sobre o outro e a incomunicabilidade entre eles se constitui em um dos problemas cruciais do nosso tempo. É preciso exercitar uma desestruturação das formas de pensar o conhecimento, a ciência e o mundo" (ALMEIDA, 2001b, p. 26).

Longe de apregoar a unificação de estilos diferenciados de dialogar com o mundo, é necessário considerar, entretanto, que existe uma forte segregação entre estas duas formas de conhecimento: a ciência e a tradição. E é inadmissível esse paralelismo 
de saberes que têm em comum o mesmo desafio: tornar possível e prazerosa a vida humana na Terra. A ciência nasce justamente da domesticação de parte dos saberes milenares da tradição, mesmo que deles tenha aos poucos se distanciado (Almeida, 2001a).

Para ter a certeza de que os mistérios do universo poderiam ser explicados dentro das suas concepções, a ciência primeiro criou um efeito de desencantamento. Afastou o mito e suas razões para um passado abolido - cemitério onde também repousam suas próprias teorias, mortas e reduzidas ao estado de formas míticas - ou para um exterior, que é o das sociedades ditas tradicionais ou com pouca racionalidade (Balandier, 1997).

É assim que diferentes culturas, portadoras de outras lógicas da natureza, passadas ou ainda vivas, possuem seus próprios saberes. Essas variações culturais não devem ser imputadas a uma deficiência - a de sociedades consideradas incapazes de ciências, como elas foram ditas incapazes de devanir histórico - ou a um arcaísmo exclusivo de qualquer racionalidade. Nessa exploração, feita fora de suas fronteiras, a ciência começou a achar os espaços da tradição e do mito; não mais os excluindo, ela os constitui às vezes como uma 'intercrítica' (ibid.).

É preciso, então, refletir sobre o suposto caráter eminentemente prático da ciência e abrir outros olhares para discussões que ampliem a compreensão dos fenômenos, sejam eles no campo material ou das idéias. É, pois, de fundamental importância para a história da ciência e da técnica perguntar pelas condições objetivas de permanência, acumulação e consolidação de outras formas do saber, que justamente com a ciência constituem o "capital cognitivo" da cultura humana (Almeida, 2001b).

"Desenvolvidos às margens do conhecimento escolar e da ciência, esses saberes da tradição são, ao longo da história, repassados de pai para filho de forma oral e experimental" (ibid.). Tais saberes têm na oralidade a sua principal fonte de transmissão. "E através desta oralidade é possível ter acesso às experiências daqueles que vivem às margens do poder, e cujas vozes estão ocultas porque suas vidas são pouco prováveis de serem documentadas" (Thompson, 2002, p. 16). 
Para Balandier (1997), a tradição é a soma de saberes acumulados pela coletividade a partir de acontecimentos e princípios fundadores. Ela exprime uma visão do mundo e uma forma específica de presença do mundo. Por essas duas razões remete a uma realidade primeira e a uma ordem que a manifesta, formando-se ao longo do tempo. Traz em si um núcleo de verdades fundamentais das quais os especialistas são os guardiões e os intérpretes; é, nesse sentido, um conhecimento "de dentro" que não é acessível a todos, e, por isso mesmo, necessariamente reservado.

$\mathrm{Na}$ medida em que permanece viva e ativa, a tradição consegue nutrir-se de imprevisto e novidades. Na medida em que é praticada, descobre seus caminhos: sua ordem não mantém tudo, porque nada pode ser mantido por puro imobilismo; seu próprio dinamismo é alimentado pelo movimento e pela desordem, aos quais ela deve finalmente se subordinar. A tradição não se dissocia daquilo que lhe é contrário, governa os indivíduos e a coletividade, porém somente alguns a conhecem inteiramente. Esses profundos conhecedores dos saberes se constituem em pequenos grupos que detêm e transmitem os conhecimentos por meio de um lento procedimento iniciático (Balandier, 1997).

No presente trabalho, o conhecimento tradicional é definido "como o conjunto de saberes e saber-fazer a respeito do mundo natural e sobrenatural, transmitido oralmente, de geração em geração" (Diegues \& Arruda, 2001, p. 32). O conhecimento tradicional não se preocupa com princípios de interesse e aplicabilidade geral e os seus critérios de validação são locais, embora venha contribuindo para gerar hipóteses e(ou) para modificar hipóteses de pesquisa (Bandeira, 2001).

Logo, o terno tradicional não será empregado de forma rígida, considerando neste trabalho que as comunidades de pescadores artesanais que dispõem de um conjunto de saberes empíricos e o utilizam nas suas práticas diárias de sobrevivência, transmitindo-o às gerações futuras por meio da oralidade, são detentoras de saberes tradicionais, sem, contudo desconsiderar a importância das discussões que tratam do conhecimento das populações que ficam entre o moderno e o tradicional. 
"Em muitas dessas sociedades, sobretudo as indígenas, há uma interligação orgânica entre o mundo natural, o sobrenatural e a organização social. Para tais comunidades, não existe uma classificação dualista, uma linha divisória rígida entre o 'natural' e o 'social', mas sim um continuum entre ambos. É, portanto, essencial ter um contraponto que na cosmologia dessas sociedades, a 'natureza' e outros conceitos como 'ecossistema', tal como a ciência ocidental entende, não são domínios autônomos e independentes, mas um conjunto de inter-relações" (Diegues \& Arruda, 2001).

O antropólogo Claude Lévi-Strauss em O pensamento selvagem (1989) ressalta a importância do conhecimento tradicional das populações indígenas, ao afirmar a existência de técnicas muitas vezes complexas, que permitem, por exemplo, transformar grãos ou raízes tóxicas em alimentos. De acordo o autor, existe nesses grupos humanos uma atitude científica, uma curiosidade assídua e alerta, uma vontade de conhecer pelo prazer de conhecer, pois apenas uma fração das observações e das experiências poderia fornecer resultados práticos e imediatamente utilizáveis. Afirma, portanto, que são duas unidades distintas de pensamento científico, não em função de estágios desiguais de desenvolvimento do espírito humano, mas dois níveis estratégicos em que a natureza se deixa abordar pelo conhecimento.

Daí a importância de não dissociar o saber tradicional do saber científico. "É importante lembrar que todas as sociedades tradicionais imprimem fortemente sobre os lugares conhecidos as significações exigidas por seu imaginário, seus sistemas simbólicos e suas práticas rituais" (Balandier, 1997, p. 101).

A ciência e o progresso aparecem como a razão e a causa do "êxito" da nossa cultura. Uma conseqüência disso é que o reconhecimento social desse saber é publicamente admitido e, nesse sentido, goza de estatuto privilegiado.

O mesmo não acontece com os outros tipos de conhecimentos como, por exemplo, o conhecimento dos pescadores. A imagem social desse grupo aparece 
condicionada, em grande parte, pela posição que essas pessoas ocupam na sociedade, à atividade produtiva da qual deriva seu saber. A credibilidade social do que o pescador diz torna-se afetada pelo o que o pescador é em relação aos seus interlocutores. Uma posição que muitas vezes está construída sobre o que fazem, mais do que como fazem as coisas. Assim, o conhecimento tradicional acaba por ficar às margens do conhecimento científico (Allut, 2000).

Conforme o exposto, fica evidenciada a existência de diferenças marcantes entre as formas pelas quais as populações tradicionais produzem e expressam o seu conhecimento sobre o mundo natural e as formas desenvolvidas pela ciência moderna. Assume-se, aqui, que essas duas visões de mundo possuem a finalidade de dar explicações para o entendimento do mundo e o diálogo entre elas pode trazer alternativas para os problemas do nosso tempo.

Nessa perspectiva, as etnociências podem ser consideradas ferramentas teóricas indispensáveis na reconstrução histórica das relações sociedade-natureza. Isso porque, nas últimas décadas, os saberes tradicionais vêm sendo reconhecidos pela comunidade acadêmica de forma mais expressiva, sendo documentados pelas etnociências. Nessa abordagem, a idéia de manejo de ecossistemas significa, em última instância, uma relação de conhecimento e ação entre as populações e seu ambiente (Diegues \& Arruda, 2001).

Segundo Leff (2001), atualmente as etnociências passam a participar da construção de uma racionalidade ambiental que tem em seu centro o princípio da diversidade cultural e de formas diferentes de apropriação da natureza. Assim, trabalhos em etnociências, como os realizados por Posey (1987, 2001); Moura \& Teixeira (1993); Almeida (2001); Begossi et. al. 2002), Marques (2001); Costa-Neto \& Marques (2001); Vannucci (1999); Nordi (1995, 1994) e Morán (1990), entre outros, têm contribuído para compor o campo teórico-metodológico dessa área do conhecimento. 


\title{
2.4 Pescadores artesanais: saberes e práticas aplicadas ao uso dos recursos pesqueiros
}

\author{
"Vamos chamar o vento (..) Vento que \\ dá na vela. Vela que leva o barco. Barco que \\ leva a gente. Gente que leva o peixe(...)”.
}

Dorival Caymmi

A população de pescadores, sobretudo os pescadores artesanais, está espalhada pelo litoral, em rios e lagos e tem seu modo de vida assentado principalmente na pesca, ainda que exerça outras atividades econômicas, como o extrativismo vegetal, o artesanato e a pequena agricultura. Embora possam ser considerados uma categoria ocupacional, os pescadores têm modo de vida peculiar (Diegues \& Arruda, 2001).

O pescador possui um conhecimento constituído por um conjunto de idéias sobre o navegar, o movimento das marés, os tipos de fundos propícios à vida de certas espécies, noções empíricas sobre os hábitos dos peixes etc., sendo que o importante não é conhecer um ou outro aspecto da atividade pesqueira, mas saber relacionar os fenômenos naturais e tomar decisões relativas à captura (Diegues, 1988, 1983).

Esse conhecimento, formado por um conjunto de práticas cognitivas e culturais, tem contribuído para assegurar a reprodução do modo de vida das populações humanas, que têm na pesca a sua principal fonte de subsistência.

A questão conceitual acerca da pesca artesanal é ampla envolvendo diversas modalidades de técnicas, modos de apropriação dos recursos pesqueiros, formas de organização da produção e distribuição dos rendimentos. Sua definição não deve apenas estar atrelada à questão do instrumental tecnológico empregado nas capturas e sim nas formas de organização social das pescarias (Cardoso, 2001).

A pesca artesanal é uma atividade que se destaca como fornecedora de proteínas de ótima qualidade para as populações humanas; multi-específica, esta utiliza grande variedade de aparelhos e, em geral, a maioria das embarcações não é motorizada; a produção é de pequena escala e se destina ao consumo familiar e ao mercado interno (Diegues, 1995 e Maldonado, 1986). 
$\mathrm{O}$ pescador artesanal exerce sua atividade de maneira individual; em pares ou em grupos, na maioria das vezes os componentes do grupo são formados por referências de parentesco, sem vínculo empregatício e a pesca é sua principal fonte de renda (Diegues, 1988; 1983 e Maldonado, 1986).

Existem nas sociedades pesqueira grupos, como os catadores de caranguejos e de moluscos, que muitas vezes passam por questionamentos de que devem, ou não serem considerados como parte da sociedade pesqueira. Sem pretensão de entrar no mérito desse debate, esses grupos serão entendidos neste trabalho como parte da sociedade pesqueira, uma vez que eles são reconhecidos pelas Colônias de Pescadores e usufruem os mesmos direito que os pescadores de peixe quando são associados às Colônias.

Os pescadores artesanais são vistos pela população em geral, e até mesmo pelos órgãos governamentais, como um "setor marginal", uma peça folclórica e muitas vezes como degradadores do ambiente (Walter, 2000). A desmistificação desse juízo é realizada por autores como Diegues (1995, 1988, 1983); Maldonado (2002, 1986); Marques (2001), entre outros. Esses pesquisadores ressaltam a importância dos pescadores artesanais como produtores de pequena escala, como fornecedores de pescado fresco e de alta qualidade para o mercado interno, salientando o seu profundo conhecimento ecológico sobre os ecossistemas aquáticos, de forma a impedir a sobrepesca e contribuir para o manejo e conservação dos recursos naturais, em especial os recursos pesqueiros.

Em termos teóricos, o uso dos recursos naturais e a propriedade comum têm sido abordados por autores como Hardin (1968), que desenvolveu a teoria denominada "Tragédia dos Comuns". O argumento central é de que numa dada área cujo recurso é de livre acesso e aberta à exploração por qualquer usuário, é esperado que cada um explore o recurso até sua capacidade máxima.

A referida teoria foi bastante criticada nas últimas décadas. Feeny et. al. (1990) estabelece uma contestação à teoria de Hardin, salientando que ela confunde propriedade comum, com livre acesso aos recursos, reduzindo as causas do declínio ambiental ao insucesso econômico da utilização dos recursos comuns, desconsiderando, assim, a 
complexidade dos sistemas sócio-econômicos e do comportamento de territorialidade sobre o uso do recurso comum.

Esses pesquisadores propõem alternativas para o manejo dos recursos naturais, entre elas, a restrição ao acesso aos recursos terrestres e aquáticos, priorizando sua utilização por comunidades locais ou grupos isolados. Essa prática beneficiaria populações humanas que tradicionalmente utilizam determinado recurso natural e evitam a sobreexploração.

Por recursos naturais entende-se aqueles que todos os organismos, incluindo os humanos, precisam para sobreviver e se reproduzir. Esses recursos incluem alimentos, água e, freqüentemente, algum tipo de proteção contra agentes estressores do ambiente, sejam de ordem física, tais como temperaturas extremas, ou biológica, como predadores ou parasitas (Kormondy \& Brown, 2002).

Todos os organismos devem equilibrar efetividade, eficiência e risco ao determinarem suas respostas aos estressores ambientais. Tal equilíbrio é necessário também para definir as estratégias para a aquisição de recursos naturais de um determinado território (ibid.).

De acordo com Begossi et. al. (2002), a territorialidade é uma forma de controlar espaço e recursos. Assim, um território é uma área de uso exclusivo de determinado grupo. $\mathrm{O}$ sentido de territorialidade ocorre quando há interferência ativa entre indivíduos, quando uma área exclusiva, o território, é defendida contra intrusos por um padrão de comportamento reconhecido pelos indivíduos (Bergon ${ }^{1}$ apud Begossi, No prelo). Esse conceito na ecologia tem sido observado em populações humanas há muitos anos. Dominar um território, ou se apropriar de um território envolve custos. Dessa forma, o recurso a ser defendido deve compensar os custos de manutenção de um dado território.

Os pescadores artesanais, tanto de água doce como marinhos, não procuram as suas presas aleatoriamente, mas as buscam em locais específicos do rio ou do mar. Em termos ecológicos, tal comportamento não surpreende, visto que na natureza os

\footnotetext{
${ }^{1}$ BERGON, M. et al. Ecology. 3 ed. Blackwell Sceince Ltd: Oxgord, 1996.
} 
organismos também não estão distribuídos uniformemente, mas sim em "manchas". Essas "manchas" são constituídas por recursos agregados que ocorrem em uma determinada área. Se esse raciocínio for transferido para a pesca, é possível supor que o pescado é em geral encontrado agregado, em "manchas", nos rios e mares. Ou seja, o que os pescadores denominam como "pesqueiros" são na realidade "manchas" de pescado, ou territórios de pesca, os locais onde as espécies capturadas são encontradas (Begossi, No prelo).

Os pescadores conhecem pontos no rio ou no mar onde certas espécies são encontradas e, em função dos aspectos seletivos da pesca, diferentes técnicas são usadas para a captura das espécies, assim como os pontos de pesca são em geral direcionados à captura de determinadas espécies. Os pontos são reconhecidos pelos pescadores através de referências aquáticas (uma laje, por exemplo) ou terrestre (uma referência de terra, uma árvore, uma casa, uma igreja), existindo similaridade com relação ao comportamento no uso dos pesqueiros entre pescadores artesanais interiores e da costa marinha (Begossi, No prelo; Diegues, 2001 e Cascudo, 1957).

A territorialidade é uma característica do manejo comunitário, pois as regras de uso estabelecidas só têm validade numa área habitada por uma dada comunidade, onde a mesma dispõe de força para fazer valer seus acordos. Essas áreas normalmente são pequenas, determinadas em muitos casos por laços de parentesco (Begossi, 1996, 1995).

Todavia, num contexto mais abrangente, considerando aspectos sócio-culturais e econômicos, Cruz (2002); Haesbaert (2002) e Morais (2001) mencionam que o território exprime referências simbólicas; é espaço aglutinador de identidades. Ultrapassa o uso, apropriação e controle de uma determinada área geográfica por um indivíduo ou grupo, pois envolve as múltiplas formas de apropriação do espaço, nas diversas escalas espaço-temporais. Logo, se territorialidade era vista como fixação e (relativa) estabilidade, hoje o território também se constrói numa forma de "mobilidade" controlada, como o "território-rede" das grandes corporações transnacionais. Assim, o processo de mundialização tem levado à desterritorialização cultural.

Isso é o que vem acontecendo no âmbito da ocupação territorial do estuário do rio Curimatáu/Cunhaú, a partir da instalação das empresas de camarão. Desse modo, as 
normas de conduta e os saberes tradicionais dos pescadores, associados à aplicação de regras comunitárias, cuja contribuição para o manejo equilibrado dos recursos pesqueiros e conservação das espécies é fundamental para o grupo, passam a ficar ameaçados com a nova configuração territorial das áreas estuarinas do Curimataú/Cunhaú. Com base teórica nos conceitos e temas ora explicitados, será conduzida a análise sociedade-ambiente no Canto do Mangue.

\subsection{Carcinicultura: contexto local e global}

"Hoje o ouro do Rio Grande do Norte é o camarão, chamam de ouro vivo”.

Pedro, pescador do Canto do Mangue.

Em Canguaretama, a implantação das fazendas de camarão teve início em 1980, no distrito de Barra de Cunhaú, passando a apresentar maiores proporções nos anos noventa. Pode-se considerar que "o processo produtivo nas fazendas de camarão vem tomando impulso através de investimento de capital, realizado pelos donos de terras que estão situados na planície flúvio-marinha do Curimataú/Cunhaú" (Silva, 2000).

O estuário do Curimataú/Cunhaú compreende três municípios produtores: Canguaretama com 17 produtores; Baía Formosa com 01, e Vila Flor com 05, ocupando uma área de 2.074,9 hectares. Desses, 1.072,2 hectares compreendem a área de viveiros (Rio Grande do Norte, 2001). Porém, de acordo com documentos do Instituto de Desenvolvimento Econômico e Meio Ambiente - IDEMA (2004), apenas 914,33 hectares estão devidamente licenciados.

As implicações na liberação das licenças ambientais para a instalação da carcinicultura residem no fato de as áreas de interesse empresarial serem as mesmas que se encontram amparadas por dispositivos legais nos âmbitos municipal, estadual e federal.

A viabilidade econômica da atividade tem ocasionado gradativamente a ocupação das áreas ditas "adequadas" à construção de tanques de cultivo (Silva \& Garavello, 2003a), conforme se observa a seguir nas Figuras 3 e 4. 


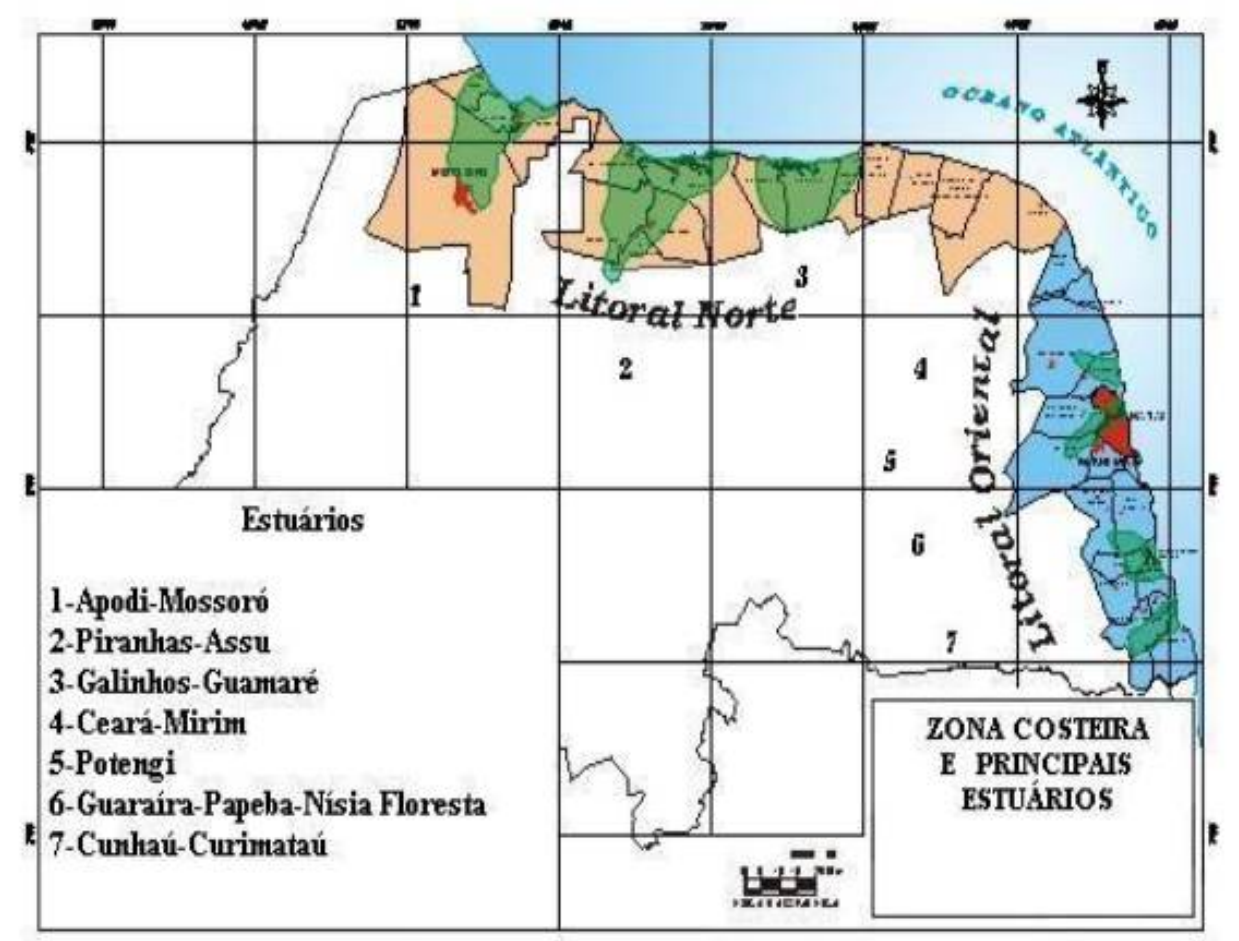

Figura 2-Principais estuários de cultivo de camarão marinho no Rio Grande do Norte Fonte: Instituto de Desenvolvimento Econômico e Meio Ambiente (IDEMA), 2002. (Adaptado)

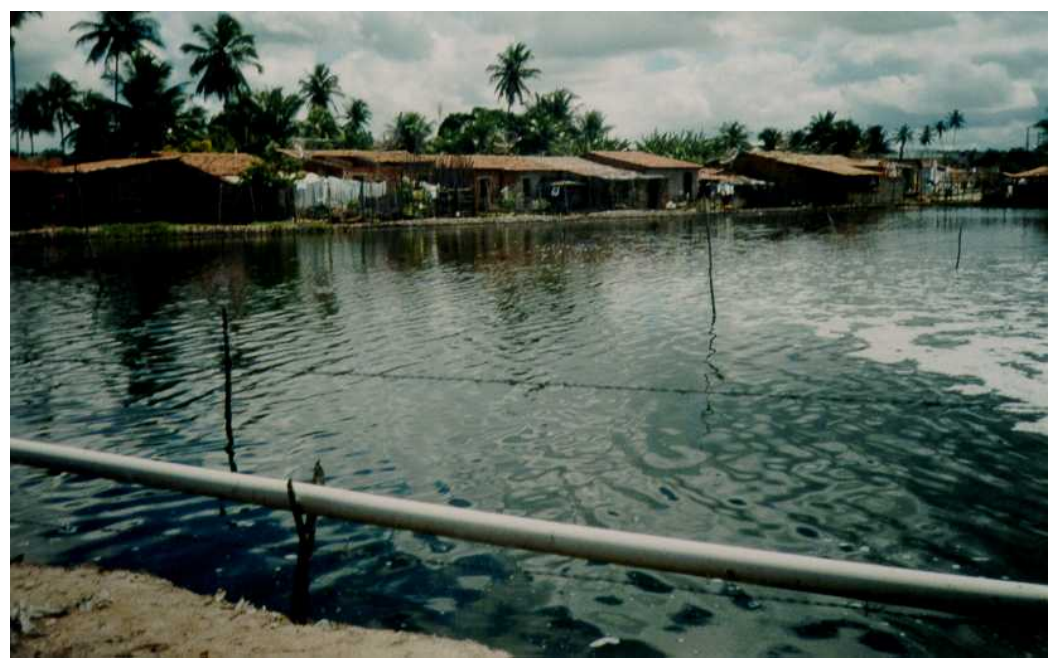

Figura 3 - Tanque de camarão instalado no Canto do Mangue, fev., 2003 
É preciso considerar a devastação ocorrida nas áreas de manguezais, nos últimos vinte anos, que estão cedendo espaço para a instalação dos tanques, pois os pescadores artesanais, dependentes diretos dos recursos dos manguezais e dos ecossistemas associados, acabam se deparando com dificuldades para realizarem suas atividades diárias de subsistência (Silva \& Garavello, 2003b).

De acordo com o CEPENE (2001), o Rio Grande do Norte possui cerca de 12.000 pescadores distribuídos ao longo do litoral. Se for considerado que a média de indivíduos por família é de cinco pessoas, estima-se que há 60.000 pessoas no Estado ligadas à pesca. Isso, sem considerar os vendedores de peixes, carpinteiros navais, confeccionadores de aparelhos de pesca, entre outros. Desse modo, a pesca artesanal, principalmente nas áreas estuarinas, pode ser considerada uma atividade que contribui para a subsistência de muitas famílias que habitam o litoral precisando se (re)pensar a forma pela qual as áreas costeiras vêm sendo ocupadas.

No Rio Grande do Norte observa-se um forte incentivo ao desenvolvimento da carcinicultura. De acordo com a Federação das Indústrias do Estado do Rio Grande do Norte - FIERN (2001), o camarão aparece na pauta dos principais produtos de exportação do Estado, sendo o quarto produto de maior expressividade no ano de 2000, representando um total de aproximadamente US\$ 14 milhões, ficando apenas atrás das exportações de confecções, melão e da castanha de caju. Já a partir de 2001, o camarão passou a atingir o primeiro lugar na pauta de exportação do Estado, como produto isolado.

A carcinicultura apresentou-se como alternativa econômica ao Estado, ainda nos anos setenta (1973) com o "Projeto Camarão" criado pelo então governador Cortez Pereira. Esse projeto visava à viabilidade técnica e econômica do cultivo de camarões marinhos no Rio Grande do Norte, com o objetivo de resolver o problema do desemprego causado pela falência das antigas salinas.

Com o apoio de órgãos governamentais, como universidades e bancos, o "Projeto Camarão" passou a ser entendido como o possível solucionador de problemas sociais na época. Em 1980, com a criação da Empresa de Pesquisa Agropecuária do Rio Grande do Norte S/A - EMPARN, os trabalhos de pesquisas desenvolvidos pelo 
governo do Estado foram transferidos para essa instituição, da mesma forma que a infraestrutura física e o pessoal do "Projeto Camarão" (Lopes Neto, s.d.).

Durante esse período, as espécies nativas (Penaeus brasiliensis e Penaeus schmitti) foram alvo de pesquisas, sendo também estudadas espécies exóticas originárias da Ásia e da América Central. Porém, até o final da década de oitenta, não se havia definido a espécie ideal para alavancar a carcinicultura no Estado (id.).

O fracasso das pesquisas em reprodução, produtividade e resistência a doenças revelou a "necessidade de se adotar e introduzir" no Brasil uma espécie com pacote tecnológico pronto. $\mathrm{Na}$ década de noventa, com o apoio da iniciativa privada, foi introduzida no país a espécie Litopenaeus vannamei, já cultivada com grande sucesso no Equador e cuja adaptabilidade às mais variadas condições de cultivo contribuiu para a viabilidade do sucesso produtivo no Brasil (Rio Grande do Norte, 2001).

No Rio Grande do Norte, existia até o final de 2003 uma área licenciada de 8.155 hectares destinada ao cultivo de camarão e 2.544.6 hectares estavam em processo de licenciamentos. Estima-se que o Estado possua cerca de 35.142 hectares "propícios" ao desenvolvimento da atividade, sendo registrados no Ministério da Agricultura cerca de 420 produtores (BRASIL..., 2003).

Porém, faz-se necessário ressaltar que as chamadas "áreas propícias" ao cultivo de camarão são aquelas próximas aos ecossistemas aquáticos, que uma vez ocupadas desordenadamente podem ocasionar danos irreversíveis ao ambiente e às populações que têm nesses ecossistemas a sua principal ocupação econômica.

De acordo com o INFORMATIVO técnico da Revista Gleba (2002), os Estados da Região Nordeste do Brasil já são responsáveis por $97 \%$ da produção brasileira de camarão marinho, apresentando um dos melhores índices de produtividade do mundo com uma média anual de cinco toneladas/hectare.

Essa atividade, conforme a Associação Brasileira de Criadores de Camarão $\mathrm{ABCC}^{2}$, tem gerado grande número de empregos no litoral do Nordeste. Até 2002 foram

\footnotetext{
${ }^{2}$ Disponível em: http//www.abccam.com.br - acesso em 03 de jan. 2004.
} 
20 mil empregos diretos e estima-se que 50 mil indiretos, sendo considerado que cada hectare de viveiro cultivado gera dois empregos diretos.

Todavia, esses números necessitam de uma análise mais aprofundada, no intuito de avaliar: quais tipos de empregos estão sendo gerados? Quais são os setores da carcinicultura que oferecem maior número de empregos? Quantos e quais empregos estão sendo oportunizados às populações locais? Quais setores industriais estão ligados à carcinicultura? Para qual público se destinam os empregos indiretos gerados pela atividade?

Somente respondendo essas e outras questões, será possível analisar a participação das populações locais na atividade e até que ponto há ou não eqüidade social, visto que a teoria econômica em que se baseia a implantação da carcinicultura é o desenvolvimento sustentável.

O Brasil está em primeiro lugar no ranking latino-americano de produtores de camarão, ultrapassando o Equador que se manteve na posição de líder até o final de 2002. Com esse resultado passou a ocupar o sétimo lugar no ranking mundial, liderado pelos chineses, sendo a espécie Litopenaeus vannamei, cultivada no Brasil, uma das mais cultivadas no mundo (BRASIL..., 2003).

No âmbito econômico é inegável a viabilidade da atividade (numa escala temporal próxima), considerando que o cultivo de camarão marinho é o segmento mais bem-sucedido da aqüicultura, representando sozinho US\$ 6,1 bilhões de dólares ou 12\% do valor total gerado anualmente pela indústria aqüícola no mundo, sendo que cerca de $75 \%$ da produção mundial de camarões cultivados concentra-se nos países asiáticos. Os $25 \%$ restantes estão no continente americano (Rio Grande do Norte, 2001).

A carcinicultura destaca-se não só no Estado do Rio Grande do Norte, como também na maioria dos Estados do Nordeste do Brasil, e em muitos países do mundo. A preocupação com a sustentabilidade ambiental dessa atividade é evidente, sobretudo em conseqüência das características migratórias das empresas, cuja busca por regiões que ofereçam condições favoráveis de cultivo vem sendo constante.

Um caso que exemplifica essa característica das empresas pode ser observado no Equador. Após a crise econômica dos últimos anos na carcinicultura, em decorrência 
dos efeitos das viroses ocorridas nos viveiros daquele país, além da redução de créditos destinados ao setor e outros estímulos econômicos, o Equador passou a perder os investimentos de criadores estrangeiros. Assim, a procura por regiões com condições favoráveis tem atraído criadores equatorianos e mão-de-obra especializada para o Brasil, entre outros países.

\section{Viabilidades e implicações decorrentes da carcinicultura}

Pesquisadores e organizações não governamentais vêm fazendo o alerta de que a carcinicultura pode ser extremamente prejudicial aos manguezais e a outros ecossistemas associados se for realizada de forma descontrolada e indiscriminada. Sugerem, portanto, a necessidade do desenvolvimento de pesquisas que possam mensurar os impactos da atividade sobre o ambiente e sobre a população humana local, bem como pesquisas que contribuam para o desenvolvimento de métodos de manejo sustentáveis na carcinicultura, auxiliando a conservação do ambiente costeiro (Correia Filho \& Canejo, 2003).

Pontes \& Arruda (2001) mencionam que no Nordeste do Brasil, onde o cultivo do camarão se desenvolveu acentuadamente na última década, urge uma atenção especial para a otimização dessa prática, tanto do ponto de vista econômico como da sustentabilidade ambiental, sobretudo, pela acelerada devastação dos manguezais ocorrida nos últimos anos, sendo preciso o desenvolvimento de pesquisas que visem a resultados conciliatórios entre o cultivo de camarão e a sustentabilidade ambiental.

Outrossim, a expressividade econômica do setor tem atraído investimentos na área de pesquisa e melhoramento genético da espécie Litopenaeus vannamei, como destaca o artigo "Rede de laboratório mapeará genoma do camarão mais cultivado no Brasil” (2003). Esse mapeamento genético será realizado por pesquisadores pertencentes a uma rede de laboratórios de onze universidades brasileiras ${ }^{3}$. Ainda segundo o artigo, o

\footnotetext{
${ }^{3}$ A Universidades de São Paulo (USP), a Universidade Estadual de São Paulo (UNESP), as federais de Santa Catarina (UFSC), do Ceará (UFCE), do Maranhão (UFMA), do Rio Grande do Norte (UFRN), do Pará (UFPA), de Pernambuco (UFPE), a Estadual de Ilhéus (UEI) e a Pontifícia Católica do Rio Grande do Sul (PUC-RS), sob a coordenação do Departamento de Genética e Evolução da Universidade Federal de São Carlos (UFSCar).
} 
conhecimento obtido com o genoma do L. vannamei poderá também servir para investigações do genoma de espécies nativas de camarão.

Por outro lado, pesquisas sobre os impactos ambientais e sócio-culturais decorrentes da atividade também vêm sendo realizadas, mesmo que de forma bastante tímida. No âmbito internacional, Primavera (1993) analisou a valorização do ecossistema de manguezal em relação à produção pesqueira das diversas espécies de valor econômico, comparando com a produção de camarão em cativeiro. Concluiu que, numa relação custo-benefício, as perdas econômicas geradas com o declínio da pesca, somadas aos prejuízos econômicos advindos dos assoreamentos dos canais navegáveis, à perda da balneabilidade das praias adjacentes e das divisas com o turismo, entre outros, levará a cifras muitas vezes maiores do que aquelas estimadas para a rentabilidade da indústria do camarão.

Órgãos não governamentais como a Global Aquaculture Alliance - GAA (2002) elaborou códigos de práticas para o cultivo responsável de camarão. Esses foram criados para fomentar uma maior conscientização ambiental por parte da indústria de camarão, no intuito de assegurar a proteção dos manguezais e os impactos potencialmente adversos da aqüicultura em regiões costeiras.

Os códigos prevêem, entre outros objetivos, o não desenvolvimento de fazendas de camarão em áreas de manguezal, a recuperação das áreas degradadas pela atividade, o monitoramento dos impactos e medidas mitigatórias para evitar danos ao ecossistema, como o lançamento de dejetos dos tanques nos estuários, freqüentemente eliminados de forma irresponsável. As áreas de manguezais são apontadas como sendo as piores para a construção de tanques de engorda, devido ao $\mathrm{pH}$ ácido com alto grau de matéria orgânica instável, uma vez que os terrenos dificilmente são drenados e secados adequadamente e porque os manguezais e outras áreas úmidas costeiras funcionam como proteção contra tormentas e ondas (GAA, 2002).

No Brasil, Coelho Júnior \& Schaeffer-Novelli (2000) pesquisaram os impactos da carcinicultura nos ecossistemas costeiros, com ênfase para o manguezal. Nesse trabalho, os autores descrevem alguns tipos de impactos decorrentes da atividade. Em linhas gerais, os impactos estão relacionados às mudanças na drenagem, desvio ou 
impedimento do fluxo das marés e mudanças nas características físico-químicas do substrato, entre outros que ainda não se pode mensurar com precisão, como mostra a Tabela 1.

Tabela 1. Tipos de impactos relacionados à carcinicultura

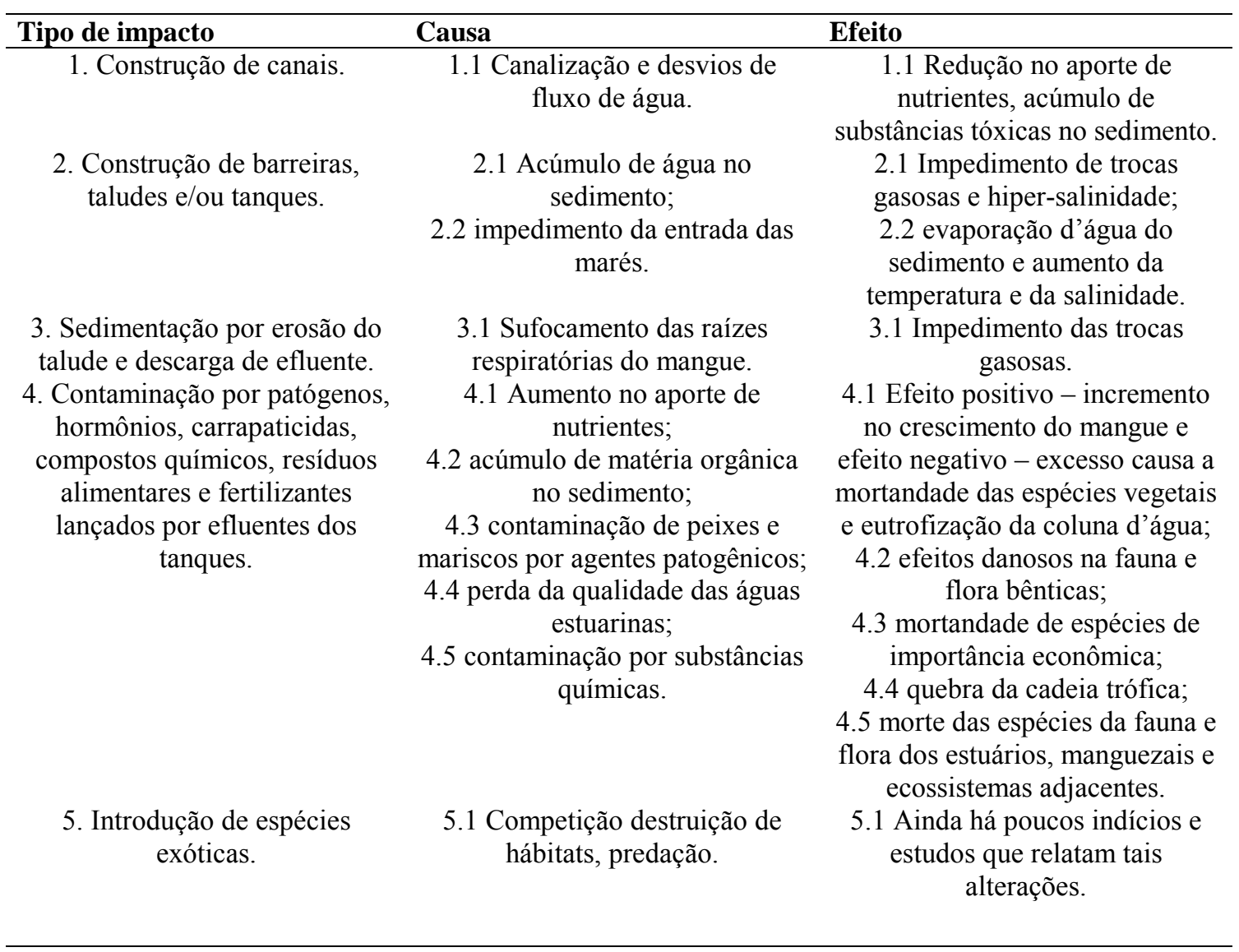

Fonte: Coelho Júnior \& Schaeffer-Novelli, 2000.

De acordo com Vannucci (1999), o maior impacto negativo sobre os manguezais do Nordeste do Brasil é causado por um desenvolvimento apressado, por muitas vezes intempestivo, do turismo e pela indiscriminada instalação de empresas de aqüicultura, sobretudo, a carcinicultura em área de manguezal.

Em relação ao Rio Grande do Norte, Silva (2000) apresentou uma proposta de zoneamento ecológico para o estuário do rio Curimataú/Cunhaú e seu entorno, onde se 
localizam diversas fazendas de camarão. Em sua tese, o autor menciona alguns dos impactos sócio-ambientais provenientes da carcinicultura no local.

Proposta semelhante foi apresentada por Galvão (2000) ao realizar um zoneamento de uso e ocupação do solo para o distrito de Barra de Cunhaú, em Canguaretama, e ao estudar impactos ambientais da criação de camarão na referida área.

Já Melo Júnior (2003, 2001 e 2000) estudou as implicações ambientais dos metais pesados em sedimentos de fundo do estuário do rio Curimataú/Cunhaú e apresentou a criação industrial de camarão, em praticamente toda a extensão da margem esquerda do referido rio, como um dos fatores potencialmente impactantes na área.

\section{Processo produtivo: considerações gerais}

O processo produtivo do camarão cultivado é bastante amplo. Não tendo a pretensão de descrevê-lo em sua complexidade, neste trabalho são realizadas considerações em linhas gerais do referido processo. Assim, a preparação dos tanques ou viveiros onde se dispõem as larvas para o crescimento e produção do camarão passa inicialmente por uma análise dos valores de $\mathrm{pH}$ do solo e da salinidade da água. Em seguida, é realizada a aração do fundo do tanque, no intuito de criar as melhores condições de sobrevivência para as larvas depositadas. Os tanques são reforçados por taludes - estradas de acesso e que os separam uns dos outros - e pelas comportas que servem para o processo de abastecimento e drenagem da água (Silva, 2000).

Após a introdução das larvas desenvolvidas em laboratórios especializados nos tanques, o camarão levará em média três meses até alcançar o tamanho para a despesca. Em seguida, o produto é beneficiado e comercializado. O camarão cultivado no Brasil tem como principais mercados consumidores os blocos econômicos, Nafta (Acordo de Livre Comércio da América do Norte) e a UE (União Européia), as Figuras 4, 5 e 6 a seguir ilustram aspectos do processo produtivo. 


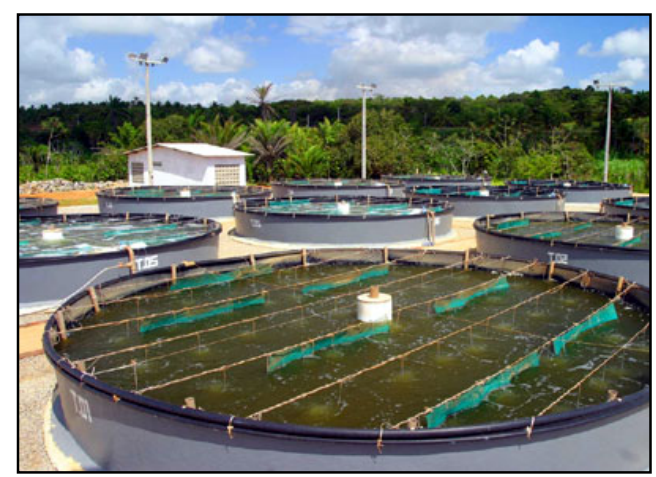

Figura 4 - Tanques de larvas

Fonte: www.camanon.com.br - acesso em 07 de fev., 2004

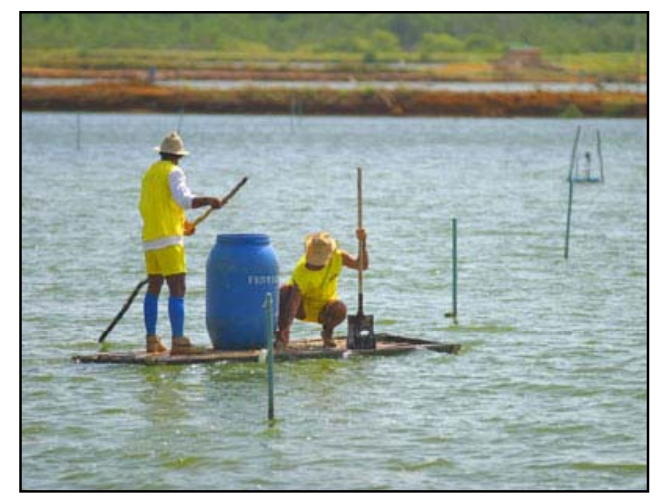

Figura 5 - Fertilização dos tanques de produção

Fonte: www.camanon.com.br - acesso em 07 de fev., 2004

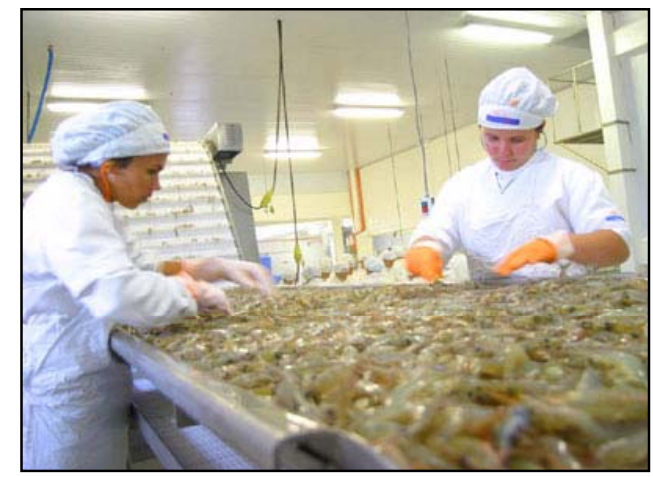

Figura 6 - Processamento do camarão

Fonte: www.camanon.com.br - acesso em 07 de fev., 2004 


\title{
2.6 Importância dos manguezais
}

\begin{abstract}
"Independente das condições aparentemente inóspitas do ambiente, o Homo sapiens sapiens ocupou e adaptou-se a diferentes nichos ecológicos, sendo capaz de fixar residência permanente sob as mais incríveis condições. Assim, para viver nas proximidades do mangue o homem desenvolveu ajustes biológicos e culturais.”
\end{abstract}

Marta Vannucci

$\mathrm{O}$ ecossistema de manguezal ocorre nas regiões tropicais, em terrenos baixos e sujeitos à ação das marés, sendo formados por solos pouco consistentes aos quais se associam comunidades vegetais e animais características desse ecossistema. O Brasil possui uma área de aproximadamente $6.786 \mathrm{~km}$ de extensão de manguezais. Estima-se a existência de uma área de $25.000 \mathrm{~km}^{2}$ desse ecossistema distribuída do Estado do Amapá até Santa Catarina (Schaeffer-Novelli et. al. 2000). Entre as espécies vegetais que constituem esse ecossistema destacam-se o mangue vermelho ou sapateiro (Rhizophora mangle), mangue siriba (Avicennia germinans), mangue branco (Laguncularia recemose) e mangue-de-botão (Conocarpus erectus).

No Rio Grande do Norte, os manguezais se distribuem ao longo do litoral oriental em seis zonas estuarinas dos rios Curimataú/Cunhaú, Trairí/Ararí, Jacu, Potengi/Jundiaí, Ceará Mirim e Maxaranguape e das lagoas Nísia Floresta, Papeba e Guaraíra. Já ao longo do litoral norte do Estado, se distribuem nas zonas estuarinas dos rios Mossoró/Do Carmo, Assu, Camurupim e Tubibau (IDEMA, 2000).

Em Canguaretama as áreas de manguezais do estuário Curimataú/Cunhaú encontram-se em elevado processo de degradação, em virtude da ação antropogênica, destacando-se: corte e queima da madeira, operações de aterros, deposição de lixo e de efluentes (sanitários e industriais), pesca predatória por parte de alguns pescadores, obras de salinas no passado e, atualmente, os projetos de aqüicultura, com destaque para a carcinicultura (IDEMA, 2000). 
Esses estressores ambientais de ordem social têm prejudicado o equilíbrio desse ecossistema e de outros associados, ocasionando transtornos às populações humanas que dependem diretamente dos recursos que ele oferece, uma vez que os manguezais funcionam como "criadouro natural" de espécies de peixes, crustáceos e moluscos, mantendo um ciclo produtivo entre o estuário e o mar, protegendo também a costa da erosão marinha, retendo sedimentos, evitando assim, o assoreamento de áreas circunvizinhas.

Além dos aspectos biológicos e ecológicos, também se destacam pela importância social, econômica e cultural, constituído-se numa das principais fontes de renda para as comunidades litorâneas. Esse ecossistema está inserido no domínio da Mata Atlântica, sendo protegido por lei como Área de Preservação Permanente - APP.

De acordo com Milaré (2001), no âmbito legal vale destacar que o Código Florestal, incluindo também as suas alterações, está em concordância com a Constituição e se constitui em norma geral que disciplina a preservação e utilização das florestas, ou vegetação específica como a Mata Atlântica e ecossistemas correlatos, a exemplo, o manguezal.

A Constituição Federal, no art. 225, declara que todos têm direito ao meio ambiente ecologicamente equilibrado (BRASIL, 1998). Assim, essa qualidade satisfatória e o equilíbrio ecológico se convertem num bem jurídico. "Pode-se dizer que os atributos ambientais não podem ser de apropriação privada, mesmo quando seus elementos construtivos pertençam a particulares, pois são bens de uso comum" (Milaré, 2001, p. 130).

Com todo esse respaldo legal, os manguezais de Canguaretama encontram-se ocupados em grande parte por empresas de camarão, como mostra a seguir Figuras 7. As suas potencialidades e os seus recursos vêm sendo intensamente explorados. Existe, portanto, a necessidade de que as áreas de preservação, de conflito, de uso permitido e de uso controlado dos recursos litorâneos sejam incluídas em projetos de gestão e gerenciamento participativos para o estabelecimento de normas na utilização dos recursos, com a finalidade de contribuir para a sustentabilidade. Este trabalho busca o 
entendimento de como vêm sendo utilizados os manguezais e seus recursos por pescadores locais e empresários da carcinicultura, no estuário do Curimataú/Cunhaú.

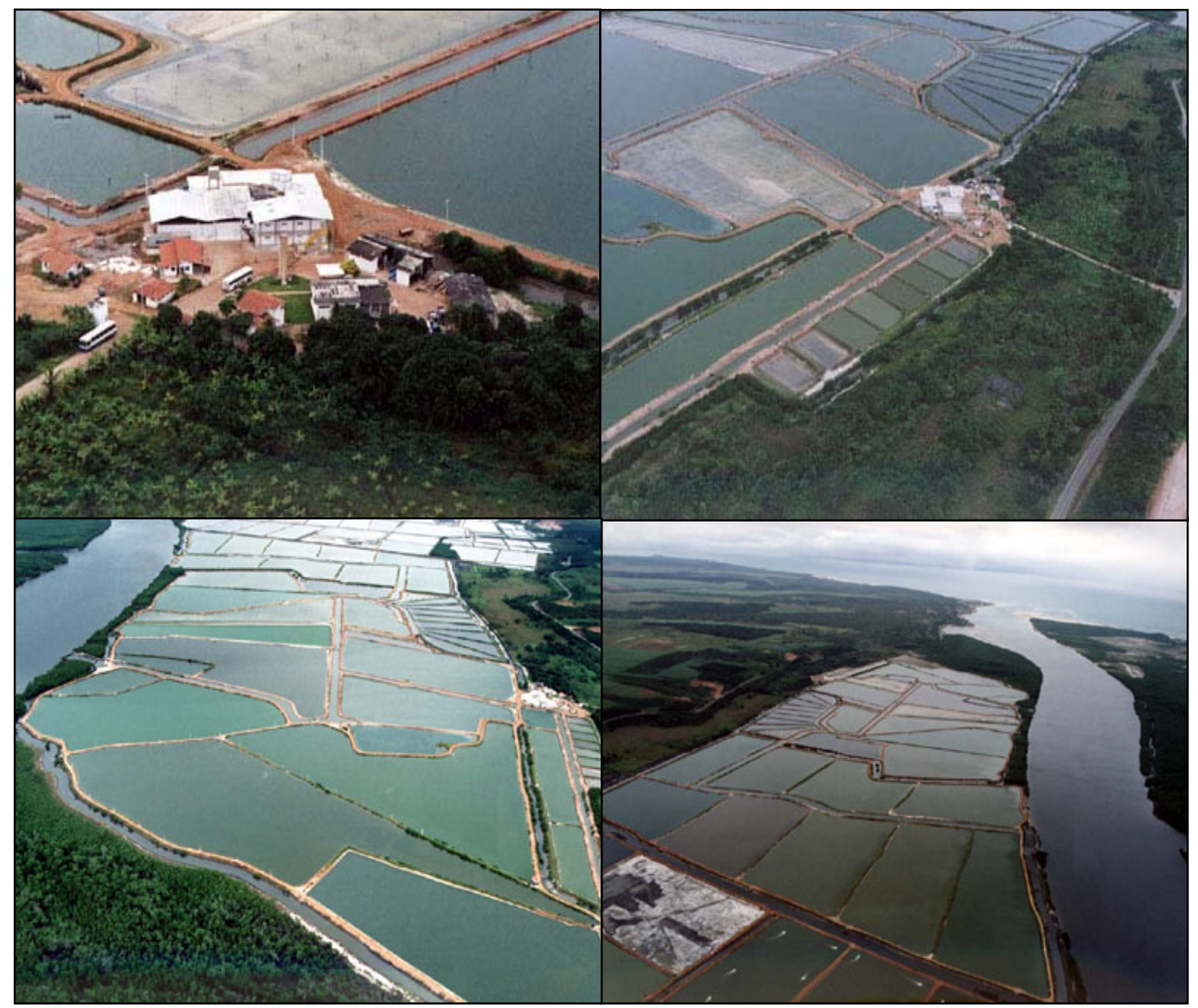

Figura 7 - Tanques de cultivo no Estuário do Curimataú/Cunhaú

Fonte: http//www.camanon.com.br - acesso em 07 de fev., 2004 


\section{METODOLOGIA}

"Na verdade, ciência faz parte da procura do transcendental que é comum a outras tantas atividades culturais: arte, música, literatura. (...) A ciência é a expressão de uma cultura (...)”.

Ilya Prigogine.

Assistimos, a todo o momento, o surgimento de novos problemas ambientais, sociais, econômicos, ético-culturais, que ultrapassam os limites territoriais das diferentes culturas e afetam toda sociedade contemporânea, por isso mesmo necessitam de uma análise complexa.

Nessa direção, emerge uma tomada de consciência de que o modelo cartesiano de pensar começa a esgotar as estratégias que moldaram, nos últimos séculos, uma ciência ultraespecializada pautada numa ordem absoluta. Morin (2000, p. 43) afirma que "a inteligência parcelada, compartimentada, mecanicista, disjuntiva e reducionista rompe o complexo do mundo em fragmentos disjuntivos, fracionando os problemas, separa o que está unido, torna unidimensional o multidimensional”.

Como Morin (2000); Prigogine (2001); Santos (2001 e 1999), entre outros pensadores contemporâneos apontam a crise pela qual passa hoje o mundo, a cultura, o homem e a ciência.

Santos (1999) menciona que a crise do modelo de racionalidade que se pauta a ciência moderna, em primeiro lugar é não só profunda, como irreversível; segundo que estamos a viver em um período de revolução científica e terceiro que os sinais dessa crise nos permitem tão-só especular acerca do paradigma emergente. 
Para Morin (2000) essa crise abre caminhos para um fazer científico que considera: que o conhecimento só pode ser pertinente se ele situar seu objeto no seu contexto e, se possível, no sistema global do qual faz parte, se ele criar uma forma incessante que separa e reúne, analisa e sintetiza, abstraí e (re)insere no concreto" (Morin, 2000, p.91).

Num esforço anticartesiano os autores mencionados rompem com as certezas e falam das incertezas do conhecimento. Boaventura de Sousa Santos (2001), afirma que a falibilidade e as incertezas devem ser compreendidas como atributos necessários para uma aproximação maior entre a ciência e a sociedade, sendo necessário considerar as múltiplas perspectivas que compõe a sociedade.

Nas palavras de D'Ambrosio (2003) é na história do conhecimento que vamos identificar as distorções e os novos caminhos possíveis para responder questões emergentes. Para isso torna-se necessário o diálogo que começa se abrir entre as ciências e as tradições.

Essa pesquisa foi conduzida, sob o prisma dessa ciência que emerge, na intenção de buscar um conhecimento contextualizado e promover um diálogo entre o conhecimento científico e o conhecimento da tradição.

\title{
3.1 Abordagens da pesquisa
}

\begin{abstract}
"Uma abordagem responsavelmente equilibrada deve reconhecer a legitimidade das duas vias de pesquisa: a qualitativa e a quantitativa e buscar, se e quando necessário, a sua integração, uma dando respostas às perguntas que a outra, pelas suas próprias limitações não consegue dar”.
\end{abstract}

José Geraldo Marques

Diante das características do problema proposto, optei pela realização da abordagem qualitativa buscando captar a realidade dinâmica e complexa do objeto de estudo no seu contexto histórico. Entretanto, "em termos de idéias, as técnicas de 
pesquisa qualitativa deveriam ser sempre complementadas com abordagens de cunho quantitativo e vice-versa" (Viertler, 2001, p. 14). A abordagem quantitativa dos problemas de investigação social constitui não a solução, mas apenas um dos vários passos necessários para superar as dificuldades de interpretação. Triviños (1987, p. 118) estabelece que:

"Toda pesquisa pode ser, ao mesmo tempo, quantitativa e qualitativa. $\mathrm{Na}$ prática ocorre que toda investigação baseada na estatística, que pretende obter resultados objetivos, fica exclusivamente no dado estatístico. Raramente o pesquisador aproveita essa informação para avançar numa interpretação mais ampla da mesma. Seu ideal é estabelecer que existe entre os fenômenos uma relação estatisticamente significativa. Ou não verificar empiricamente suas hipóteses, ou determinar o porquê delas terem sido rejeitadas".

$\mathrm{Na}$ verdade, "existe uma indissolubilidade lógica e metodológica entre a abordagem quantitativa e qualitativa, pois são como as duas faces da mesma moeda" (Viertler, 2001, p. 14). Autores como Thompson (2002), Marques (2002) e Queiroz (1987), entre outros, chamam a atenção para o fato de que o emprego das técnicas

qualitativas poder coexistir tranqüilamente com a aplicação de técnicas quantitativas. Neste trabalho optou-se por utilizar as duas abordagens, uma em complementação à outra.

\subsection{Abordagem qualitativa}

Entre os tipos de pesquisa qualitativa, optei por empregar o estudo de caso, caracterizado "fundamentalmente, do ponto de vista da medida dos dados que ele apresenta, pelo emprego, de modo geral, de técnicas qualitativas e do o uso de uma estatística básica" (Triviños, 1987, p. 135), permitindo, assim, uma análise qualitativa e 
quantitativa dos dados. Nesta categoria de pesquisa, o objeto é a unidade que se analisa profundamente.

Macedo (2000) apresenta algumas características que dão feições qualitativas ao estudo de caso, tendo como pressuposto que o conhecimento não é algo acabado de uma vez por todas. Nos estudos de caso assume-se que haverá sempre um acabamento precário e provisório, sendo que o conhecimento é visto como algo que se constrói e se refaz constantemente. Dessa forma, o pesquisador estará sempre buscando novas respostas e novas indagações no desenvolvimento do seu trabalho. Já Becker (1999, p. 118) estabelece que:

"O estudo de caso geralmente tem um propósito duplo. Por um lado, tenta chegar a uma compreensão abrangente do grupo em estudo: quem são seus membros? Quais são suas modalidades de atividade e interação recorrentes e estáveis? Como elas se relacionam umas com as outras e como o grupo está relacionado com o resto do mundo? Ao mesmo tempo, o estudo de caso também tenta desenvolver declarações teóricas mais gerais sobre regularidades do processo e estruturas sociais".

Nessa perspectiva, os vários fenômenos revelados pelas observações do investigador têm que ser todos incorporados ao seu relato de grupo e em seguida receber atribuições de relevância teórica. Becker (op. cit.) afirma ainda que postos os objetivos do estudo de caso, estes mal podem ser conscientizados; é utópico supor que se pode ver, descrever e descobrir a relevância teórica de tudo. Os investigadores tipicamente terminam se concentrando nuns poucos problemas que parecem ser de maior importância no grupo estudado - problemas que se ligam a muitos aspectos da vida e do estudo do grupo.

A preocupação de compreender os fenômenos na sua subjetividade e na sua complexidade exige análises que vão além do estudo fragmentado e(ou) reducionista, necessários à compreensão do todo. Assim sendo, houve uma preocupação em buscar 
suporte metodológico na etnociência. Contudo, não tenho pretensão de realizar um estudo aprofundado em etnoecologia, e sim estabelecer um diálogo com essa área do conhecimento, contribuindo para a valorização do conhecimento local. As ferramentas dessa linha de pesquisa podem fornecer subsídios para o presente trabalho. Dessa maneira, utilizei os princípios da etnoecologia sob a luz das formulações de Marques (2001, p. 15) que estabelece:

\begin{abstract}
"Trata-se de uma possibilidade a mais - talvez mais completar que alternativa de ser em relação a outros modos de praticá-la e seria abrangente no sentido de: (a) aceitação de que a pesquisa etnoecológica pode ser feita em qualquer ecossistema (inclusive urbano) e em qualquer contexto sócio-cultural (inclusive o de letrados em sociedades industriais); (b) o reconhecimento da etnoecologia como um campo de cruzamento de saberes; (c) a busca de integração entre a antropologia e a biologia, porém indo além (quando possível, bem além) disso; (d) a insistência em uma metodologia cientificamente enquadrável, mas que permita transgressões responsáveis (integrando subjetividade e objetividade) e heterodoxias assumidas (integração razão e emoção); (e) o enfrentamento da quantificação necessária, porém enfatizando o tratamento qualitativo de realidades ocultáveis pela insuficiência da fala dos números".
\end{abstract}

Ainda conforme Marques (2001), a etnoecologia é um campo de pesquisa (cientifica) transdisciplinar que estuda os conhecimentos, crenças, sentimentos e comportamentos que intermediam as interações entre as populações humanas que os possuem e os demais elementos dos ecossistemas que as incluem, bem como os impactos ambientais daí decorrentes. 


\section{A trajetória do campo}

Na presente pesquisa a fase exploratória teve inicio em janeiro de 2003, quando visitei o município de Canguaretama e procurei o presidente da Colônia de Pescadores para fazer um levantamento dos pescadores artesanais associados e que residiam na comunidade do Canto do Mangue.

Assim, esclareci ao presidente da Colônia, Luiz Marques da Cruz, a pretensão de desenvolver uma pesquisa com fins acadêmicos na comunidade do Canto do Mangue. Não houve restrições por parte do Sr. Luiz, mas ele me advertiu sobre as possíveis dificuldades em conseguir a colaboração dos membros da comunidade.

Mediante a lista que havia elaborado com os nomes dos pescadores associados na Colônia, ainda no mês de janeiro de 2003 ocorreu um segundo retorno ao campo, na intenção de visitar alguns dos pescadores que faziam parte da referida lista.

Esse segundo retorno não foi muito produtivo: minha tentativa de realizar visitas nas casas dos pescadores foi complicada devido à ausência de uma pessoa que pudesse me apresentar transmitindo confiança, aos moradores da comunidade. Assim, na volta a Natal, identifiquei uma ex-moradora do município (residente atualmente em Natal) que passou a me acompanhar em visitas posteriores na área de estudo.

No retorno ao Canto do Mangue, no final de janeiro de 2003, a colaboração dessa acompanhante facilitou a identificação dos pescadores listados anteriormente e de outros moradores locais. Os contatos e a convivência possibilitados nessa fase foram estruturalmente importantes para a identificação dos principais elementos da pesquisa, para delimitação do problema, bem como para a elaboração dos critérios de escolha do estudo de caso.

Consolidei, a partir desse momento, a opção de investigar as mudanças ocorridas no modo de vida dos moradores locais, e passei a registrar no caderno de campo as observações, reflexões e as conversas informais com os moradores. Para Viertler (2002), o uso de um diário, onde são anotadas desde as observações feitas até as impressões subjetivas tidas pelo pesquisador, com relação a fatos ocorridos na comunidade em que desenvolve o seu trabalho, torna-se indispensável. Impressões 
subjetivas sobre fenômenos desconhecidos e intuições podem vir a constituir um instrumental precioso para futuros "insights", podendo ou não confirmar previsões baseadas em teorias científicas.

\section{Coleta de dados}

Entre os procedimentos indicados para a coleta de dados em estudo de caso, utilizei levantamento documental, entrevistas e observações livres.

Dessa forma, os documentos foram pesquisados na Biblioteca Municipal de Canguaretama e na Colônia de Pescadores - Z 06. Em Natal, a busca foi realizada no Instituto de Desenvolvimento Econômico e Meio Ambiente do Rio Grande do Norte IDEMA; Federação de Pescadores do Rio Grande do Norte; Secretaria de Agricultura e Pesca do Rio Grande do Norte - SAPE; Federação da Indústria do Estado do Rio Grande do Norte - FIERN; Instituto Brasileiro do Meio Ambiente e dos Recursos Naturais Renováveis - IBAMA; Universidade Federal do Rio Grande do Norte - UFRN; Empresa de Pesquisa Agropecuária do Rio Grande do Norte S/A - EMPARN; Instituto Histórico e Geográfico do Rio Grande do Norte, meio on line no site da Associação Brasileira de Criadores de Camarão - ABCC.

A entrevista foi uma outra técnica utilizada, por permitir um maior aprofundamento das informações obtidas. Viertler (2002) menciona que a entrevista pode ser considerada uma das técnicas nas quais ocorrem uma relação de comunicação mais equilibrada entre a visão êmica (do pesquisado) e a visão ética (do pesquisador).

Por meio da entrevista mantive como objetivo apreender elementos significativos sobre a dinâmica da comunidade nos âmbitos: social, cultural, econômico e ecológico, além das subjetividades e dos conflitos referentes à trajetória das transformações ocorridas no espaço-tempo. A realização dessas entrevistas ocorreu nos meses de janeiro, fevereiro, março e julho de 2003.

Procurei entrar em contato com um número significativo de moradores. Contudo, no início, poucos se disponibilizaram a participar de uma conversa e responder às questões levantadas. Ainda assim, esclareci aos entrevistados a importância de expressarem-se livremente; isso fez com que aos poucos eles fossem perdendo o receio 
de falar sobre as mudanças ocorridas na comunidade. Essas entrevistas foram realizadas nas dependências da Colônia de Pescadores - Z 06 e nas residências dos(as) entrevistados(as), sendo gravadas em fitas cassetes com a autorização prévia dos(as) envolvidos(as).

$\mathrm{Na}$ primeira entrevista contei com o apoio da minha acompanhante, exmoradora do município, que passou a me auxiliar no trabalho de campo. Essa maneira de proceder, que atendia ao costume da referência familiar, afastou aos poucos as desconfianças em relação à estranha que eu havia significado num primeiro momento. Assim, o inicio das entrevistas sobre o universo pesqueiro e a dinâmica da comunidade ocorreu com o Sr. Francisco de Assis da Silva, conhecido como Quinca e sua esposa Sra. Maria Antônia Duarte, conhecida como Dona Tonha (Figura 8), aos poucos eles foram apontando os demais pescadores que faziam parte da lista composta no início do trabalho de campo. O Sr. Quinca e sua esposa foram importantes contatos dentro da comunidade, sempre me apresentando a possíveis colaboradores.

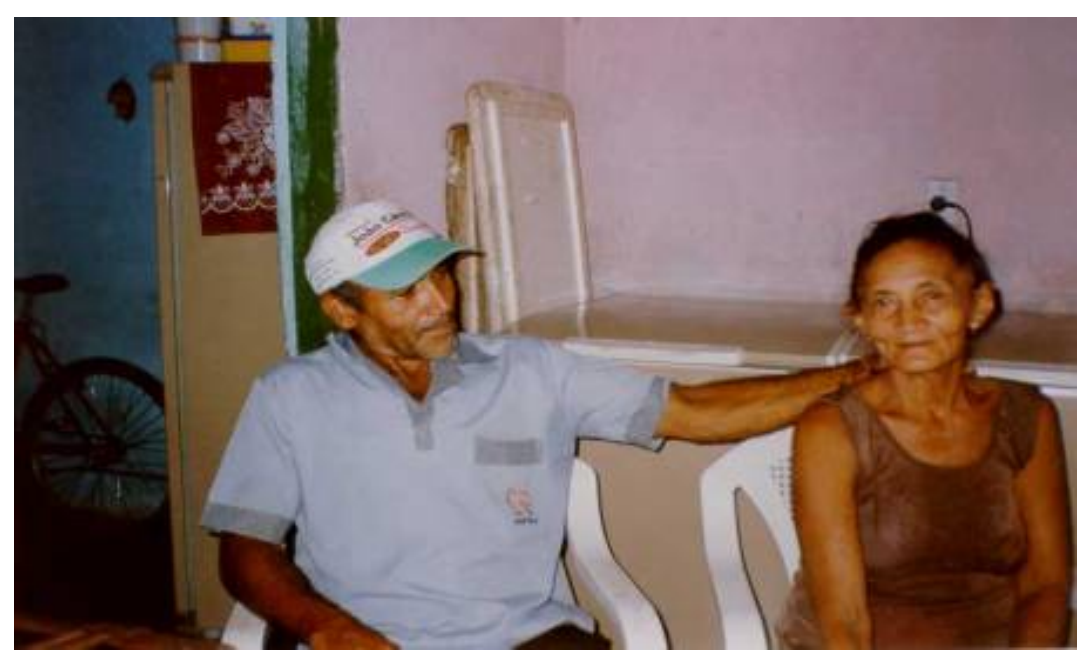

Figura 8 - Sr. Quinca, pescador e Tonha, marisqueira, fev., 2003

No primeiro momento entrevistei pescadores, as esposas e filhos, bem como as marisqueiras. Posteriormente, realizei entrevistas com funcionários das empresas de camarão e outros membros da comunidade que se encontravam envolvidos na atividade 
pesqueira. Foram ouvidas 34 pessoas no total, das quais 23 foram em entrevistas gravadas, enquanto 11 foram registradas no caderno de campo. Para compor os perfis dos participantes, utilizei os dados fornecidos nas entrevistas e os registros dos pescadores disponíveis na Colônia - Z 06.

Concomitante à realização das entrevistas, registrei observações no caderno de anotações. Conforme Becker (1999), as observações dão acesso a uma ampla gama de dados, inclusive aos tipos de dados cuja existência o investigador pode não ter previsto no momento em que começou a estudar e, portanto, sua realização é bem adequada aos propósitos de estudo de caso.

\section{Análise e interpretação dos dados}

Para Lüdke \& André (1986), esta etapa pode ter três finalidades: estabelecer uma compreensão dos dados coletados, confirmar ou não os pressupostos da pesquisa $\mathrm{e}(\mathrm{ou})$ responder às questões formuladas e ampliar o conhecimento sobre o assunto pesquisado, articulando-o ao contexto cultural do qual faz parte. As autoras ressaltam ainda que essas finalidades são complementares.

Para a operacionalização da análise foi realizada uma leitura minuciosa do material, até chegar a uma espécie de "impregnação do seu conteúdo" (Lüdke \& André, op. cit.). Procurei identificar os temas relevantes para os objetivos da pesquisa, bem como as idéias centrais, visando o estabelecimento de categorias descritivas. Adotei o mesmo procedimento na leitura e análise das observações registradas no caderno de anotações e dos documentos levantados (projetos, relatórios, matérias jornalísticas, boletins técnicos e leis).

\subsection{Abordagem quantitativa}

Nesta pesquisa utilizei, também, estatísticas, notadamente análise de tendência central, dispersão e correlação, com o objetivo de descrever e analisar os dados quantitativos, de maneira a obter valores representativos das variáveis indicativas do 
perfil da comunidade pesqueira, bem como do comportamento da produção de pescado frente à inserção da carcinicultura no município de Canguaretama.

As entrevistas foram realizadas com amostra de 34 pessoas, que corresponde a $15 \%$ da população residente na comunidade. Essas atenderam aos seguintes critérios: ser pescador há mais de dez anos, ser morador da comunidade, ser funcionário das empresas de camarão ou estar envolvido de alguma forma na comunidade do Canto do Mangue e seu entorno. As entrevistas me permitiram traçar o perfil dos comunitários em relação ao nível de escolaridade, à profissão, faixa etária, número de filhos por famílias, estado civil, naturalidade e sexo.

Os dados quantitativos relativos à produção pesqueira e ao cultivo de camarão em cativeiro foram pesquisados em periódicos do IBAMA (1993, 1994, 1995, 1996, 1997, 1998); CENEPE (1999, 2000, 2001, 2002) e na ABCC (2004) no período de 1993 a 2002, permitindo a formação de um banco de dados.

Essas informações foram analisadas para compreensão de questões relacionadas com a correlação, comportamentos lineares e não lineares; causalidade e dependência entre elas. Os cálculos necessários foram realizados com o auxílio do software Excel e os parâmetros estatísticos determinados, descritos a seguir, segundo Pérez (2000) e Fonseca et. al. (1986):

\section{Média $(\bar{X})$}

A constituição de um conjunto de dados amostrais pode ser representada por valores de tendência central. Neste estudo utilizou-se a média aritmética, definida abaixo.

Sejam os valores de uma variável $\mathrm{X}: \mathrm{x}_{1}, \mathrm{x}_{2}, \mathrm{x}_{3}, \ldots \mathrm{x}_{\mathrm{n}}$, portanto " $\mathrm{n}$ " valores. A média aritmética de $\mathrm{X}$ é representada por $(\bar{X})$ e definida pela eq. (1). 


$$
\bar{X}=\frac{\sum_{i=1}^{n} x_{i}}{n}
$$

Sendo:

$X_{i}$ - é o i-ésimo elemento da amostra

$n-\mathrm{n}^{\mathrm{o}}$ de elementos da amostra

\section{Desvio-Padrão (S)}

A variabilidade representa a maior ou menor diversificação dos valores em torno de uma medida de tendência central, sendo dada pelo desvio-padrão $(\mathrm{S})$, conforme eq. (2).

$$
S=\sqrt{\frac{\sum_{i=1}^{n}\left(x_{i}-\bar{x}\right)^{2}}{n}}
$$

Sendo:

$\bar{x}-$ média da amostra

$X_{i}$ - valor de ordem i da amostra

\section{Análise do Coeficiente de Correlação (r)}

O coeficiente de correlação mostra o grau de dependência entre duas ou mais grandezas. Assim, para fazer a avaliação do grau de correlação entre a produção de caranguejo e a produção de camarão em cativeiro foi necessário o uso do Coeficiente de Correlação de Pearson (r), conforme a eq. (3). 


$$
r=\frac{n \sum x y-\left(\sum x\right)\left(\sum y\right)}{\sqrt{\left[n \sum x^{2}-\left(\sum x\right)^{2}\right]\left[n \sum y^{2}-\left(\sum y\right)^{2}\right]}}
$$

Sendo:

$X$ - produção

$y$ - produção de caranguejo

$n-\mathrm{n}^{\mathrm{o}}$ de observações

Pearson dividiu o coeficiente em categorias, conforme o grau de dependência, como é apresentado na Tabela 2.

Tabela 2. Classificação de Pearson

\begin{tabular}{cc}
\hline Coeficiente de Pearson “r” & Grau de Correlação \\
\hline $0<r \leq|0,25|$ & Pequena \\
$|0,25|<r \leq|0,50|$ & Fraca \\
$|0,50|<r \leq|0,75|$ & Grande \\
$|0,75|<r \leq|1|$ & Forte \\
$r=|1|$ & Perfeita \\
\hline
\end{tabular}

Fonte: Fonseca et al. 1986. 


\subsection{Cenário da pesquisa}

\section{Histórico}

De acordo com o IDEMA (1999), o primeiro núcleo colonizador do atual município de Canguaretama foi a aldeia Gramació, fundada em 1743 por um jesuíta, o padre André do Sacramento. A aldeia Gramació foi elevada à condição de vila e recebeu o nome de "Vila Flor", em obediência à Carta Régia de 03 de maio de 1755, que transformava em vilas os antigos aldeamentos indígenas. Com a expulsão dos jesuítas, a sede municipal de Vila Flor foi transferida para o povoado de Uruá com a denominação de Canguaretama, em 19 de julho de 1858, pela da Lei $\mathrm{n}^{\mathrm{o}}$ 567, criando assim, o município de Canguaretama. No dia 16 de abril de 1885, a Lei Provincial no 955 elevou a sede do município à categoria de cidade, instalada em 18 de setembro de 1885 .

A cana-de-açúcar foi a primeira atividade econômica que a região na qual encontra-se Canguaretama conheceu. Colonizadores ligados a Jerônimo de Albuquerque Maranhão criaram o Engenho Cunhaú, primeiro engenho de açúcar do Estado. Em 1630, os holandeses conquistaram a capitania pernambucana, na época a maior área de produção de açúcar do mundo. Pouco depois, 1633, invadiram o Rio Grande do Norte dominando a capital do Estado, Natal, batizando-a como "Nova Amsterdã" (Cascudo, 1955).

A partir do domínio de Natal, os holandeses conquistaram em 1934 as povoações onde se localizavam os engenhos de açúcar do Rio Grande do Norte, e tomaram o controle da produção açucareira. Um desses engenhos era o Engenho Cunhaú (localizado no atual município de Canguaretama). Os holandeses aliaram-se aos índios na conquista do Rio Grande do Norte e participaram de verdadeiros massacres. $\mathrm{O}$ Engenho Cunhaú foi palco de um desses cruéis acontecimentos: o massacre dos fiéis (católicos) pelos holandeses em 16 de julho de 1645 (Cascudo, 1955).

Os holandeses foram expulsos do Brasil e, conseqüentemente, do Rio Grande do Norte em 1654, depois de vários combates e mais de duas décadas de domínio dessa capitania, que nesse período era província subordinada à Paraíba. 
Assim, foi a partir da implantação da sede do Engenho de Cunhaú que se deu o processo de evolução e organização espacial de Canguaretama. Inicialmente, com base na estrutura fundiária canavieira, conforme o exposto, e, posteriormente, com a realização de outras atividades econômicas expressivas, como a atividade salineira, que passou a se expandir economicamente a partir do século XX e se manteve forte até a metade do referido século. Já nos anos de 1968, com a queda na produção do sal e com o parque salineiro do Estado se fixando no litoral setentrional, também chamado de "Costa Branca", devido às melhores condições ambientais e aos incentivos da extinta Superintendência de Desenvolvimento do Nordeste - SUDENE, que mecanizou a produção do sal e atraiu grupos de investidores nacionais e estrangeiros para o litoral setentrional do Estado, as salinas de Canguaretama entram em decadência (Barreto, 1985).

A atividade salineira deixou nas terras que ocupava, no distrito de Barra de Cunháu, ao longo do estuário do rio Curimataú/Cunhaú uma considerável área de manguezais devastada, cujo agravamento vem sendo observado nos dias atuais.

\section{Caracterização geográfica}

Do ponto de vista geográfico, Canguaretama localiza-se no sudeste do Rio Grande do Norte, a $77 \mathrm{Km}$ de Natal, entre as coordenadas $06^{\circ} 17^{\prime} 05^{\prime \prime}$ e $06^{\circ} 22^{\prime} 25^{\prime \prime}$

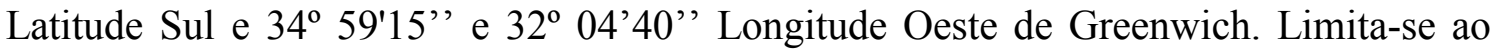
norte com o município de Tibau do Sul, Vila Flor e Goianinha; ao sul com o Estado da Paraíba; ao leste com o município de Baía Formosa e com o Oceano Atlântico, e ao oeste com os municípios de Espírito Santo e Pedro Velho. Possui dois distritos: Barra de Cunhaú e Piquiri, e ainda 08 comunidades rurais (IDEMA, 1999).

Possui um total de 27.011 habitantes $^{4}$, dos quais 16.924 residem na área urbana e 10.087 residem na área rural. Em relação ao processo urbanístico, apresenta semelhanças com as demais cidades do litoral do Estado, exceto Natal. O município

\footnotetext{
${ }^{4}$ Fonte: IBGE, Censo Demográfico - 2000. Disponível em: htpp.www.ibge.org.br - acesso em 02 de maio de 2003.
} 
dispõe de uma rede básica de serviços e utilidade pública, que atende normalmente às necessidades comunitárias nos setores de energia elétrica, água, telefones e postos/unidades de saúde pública (Silva, 2000).

Conforme o IDEMA (1999), o município apresenta tipo climático tropical subúmido com média de precipitação pluviométrica anual de 1.341,0 mm. O período chuvoso estende-se de janeiro a agosto; a temperatura média anual é de $25,6^{\circ} \mathrm{C}$, com umidade relativa do ar acima de $80 \%$ e ventos fundamentais de sudeste, "alísios".

A formação vegetal é composta por remanescentes da Mata Atlântica, e Manguezais, além da vegetação de tabuleiro litorâneo. Os tipos de solos que predominam são: as Areias Quartzosas Distróficas, com baixa fertilidade natural, textura arenosa, relevo plano, excessivamente drenado e bem profundo, e os solos Aluviais Eutróficos, com fertilidade natural alta, textura argilo-arenosa, areno-argilosa, argilosa e arenosa, relevo plano, imperfeitamente a moderadamente drenado, medianamente profundo. Nas áreas de solos Aluviais Eutróficos são cultivadas cana-de-açúcar, pastagens, além da fruticultura (coqueiros, mangueiras, laranjeiras, bananeiras e mamoeiros).

Em relação à caracterização geológica-geomorfológica, o município encontrase a menos de 100 metros de altitude. Está inserido, principalmente, na área de abrangência da Formação Barreiras, com Idade do Terciário-Superior. As rochas da Formação Barreiras estão recobertas localmente por extensas coberturas arenosas coluviais $^{5}$ e eluviais ${ }^{6}$ formando solos altamente permeáveis e lixiviados.

Próximas ao litoral encontram-se as paleodunas, ou dunas fixas com idade do Quaternário, compostas por areias de origem marinha, que foram transportadas pela ação dos ventos, formando cordões, atualmente fixados por vegetação.

Acompanhando a faixa litorânea, sedimentos estão depositados pelos ventos, compondo as dunas móveis ou dunas recentes, enquanto nos vales dos leitos dos principais rios que banham a área do município estão depositados os sedimentos de origem continental formadores dos aluviões recentes.

\footnotetext{
${ }^{5}$ Material transportado de um local para outro, principalmente por efeito da gravidade.

${ }^{6}$ Solos formados basicamente de elementos da rocha-matriz.
} 
Canguaretama dispõe de corpos d'água subterrânea de excelente qualidade química, podendo ser utilizada praticamente para todos os fins. Em relação às águas superficiais, compõem as bacias hidrográficas: Curimataú $70 \%$, Catu $50 \%$ e Guaju $20 \%$ (IDEMA, 1999).

$\mathrm{O}$ rio Curimataú, de grande expressividade no município, tem sua nascente na Serra do Cariri-Velho na Paraíba, passando pelo planalto da Borborema e entrando no Rio Grande do Norte na localidade de Boqueirão, no município de Nova Cruz. Apenas o baixo curso do rio encontra-se em território do Rio Grande do Norte, sendo parcialmente perene. Ao percorrer as proximidades do antigo Engenho de Cunhaú passa a receber a denominação Curimataú/Cunhaú. ${ }^{7}$

A comunidade "pesqueira", o Canto do Mangue e seu entorno, unidade empírica de referência desta pesquisa, se constitui em tradicional bairro de pescadores de Canguaretama, situado nas imediações da área de manguezal, próximo ao fluxo da maré. Está localizado aproximadamente a $10 \mathrm{~km}$ da Praia de Barra do Cunhaú, na qual deságua o rio Curimataú/Cunhaú. A comunidade é margeada pelo rio Pituassu, que percorre 15 $\mathrm{km}$ da sua nascente em Canguaretama até desaguar no Curimataú/Cunhaú. Ao longo do percurso do Pituassu e seus afluentes, encontram-se os aglomerados onde residem famílias de pescadores: Bairro da Rua do Porto e Rua do Quadro. Neste trabalho, esta última é entendida como a rua principal da comunidade pesquisada (Quaresma, 1987).

No Canto do Mangue e na Rua do Porto encontram-se as populações de baixa renda que mantiveram a pesca artesanal como principal atividade de subsistência. Essa característica rendeu a Canguaretama a tradição de cidade pesqueira, com destaque, para a produção de caranguejo-uçá (Ucides cordatus).

O cadastro da Colônia de Pescadores - Z 06, município de Canguaretama, registra em 2004 um total de $376^{8}$ pescadores. No entanto, esse número exclui os pescadores que não contribuem com a associação, chamados de "pescadores

\footnotetext{
${ }^{7}$ Denominação atribuída ao rio pelos moradores locais.

${ }^{8}$ Fonte: Mapa de Controle Anual das Mensalidades dos Associados, 2004 - Colônia de Pescadores - Z 06 Canguaretama/RN.
} 
clandestinos", sendo que na comunidade pesquisada foram identificados 76 pescadores ${ }^{9}$ entre sócios e não sócios da Colônia.

Em pesquisa realizada por Quaresma (1987), o número de associados à Colônia de Pescadores de Canguaretama era de 350, sendo que grande parte dos pescadores também não era cadastrada. Esses números podem sofrer variações de acordo com vários fatores: valor mensal da contribuição, período de escassez de pescado, direitos a benefícios sociais e até mesmo a simpatia e credibilidade que o presidente da Colônia exerce na comunidade.

No Canto do Mangue praticamente todos os moradores estão envolvidos de forma direta ou indireta com a pesca artesanal, e aqueles que não exercem a atividade pesqueira com a intenção de mercado realizam-na como complemento à dieta alimentar.

${ }^{9}$ Fonte: Pesquisa de Campo, 2004. 


\section{RESULTADOS E DISCUSSÕES}

"Só perde o sentido aquilo que não é percebido como visado pelo passado. O que não foi uma coisa revista por nosso espírito é alargamento das fronteiras do presente, lembranças de promessas não cumpridas”.

Walter Benjamim

\subsection{As metamorfoses ocorridas: uso do território e dos recursos}

As lembranças do passado estão sempre nas referências do presente, no entrelaçamento das lembranças dos moradores do Canto do Mangue, mergulhei junto com eles em outros tempos, tão danosos ao ambientes quanto está sendo o atual. A partir do fim da ocupação do estuário do rio Curimataú/Cunhaú pelas salinas, "o tempo do sal", passo a analisar a trajetória de um "novo" tempo-espaço nessa comunidade, "o tempo do camarão".

Assim, de acordo com as entrevistas realizadas foi possível constatar que no passado, Canguaretama dispunha de terras em áreas circunvizinhas aos manguezais, as quais não despertavam o interesse dos seus proprietários. Já a partir da década de oitenta, com o advento da substituição das antigas salinas pelos primeiros viveiros de camarão, essas terras passaram a sofrer gradativamente uma forte especulação imobiliária, sobretudo, a partir de 1990.

A procura por terrenos localizados às margens ou no estuário do rio Curimataú/Cunhaú fez com que as famílias proprietárias de lotes ou de salinas desativadas voltassem a ter uma fonte de renda. Antes, a maioria desses terrenos próximos ao Canto do Mangue ficava arrendada em caráter de meia para agricultura de 
subsistência. O regime de arrendamento era realizado entre os proprietários e os agricultores. Entre os arrendatários havia pescadores do Canto do Mangue, cujo cultivo das várzeas era pago com os produtos da colheita.

Em geral, eram cultivados o milho, o feijão, a batata e a mandioca, além de pequenas hortas. Com o arrendamento e(ou) venda dessas terras para a implantação dos viveiros de camarão, ocorreu um rompimento dos acordos realizados entre proprietários e pescadores.

“Essas terras eram para se plantar. Quando o Major Lula [um dos proprietários de terras da área] morreu, a filha dele Dona Iara foi quem ficou tomando conta de tudo. Ela tinha o gado e como eles ficavam presos, daí o povo plantar macaxeira, batata, milho, o feijãozinho. E tudo isso já ajudava. Quando chegava o tempo de soltar o gado aí sim, se apanhava [colhia] tudo o que havia plantado porque o gado comia o roçado. Agora era assim: o mato que ficasse era comida para o gado dela [D. Iara]. O pasto era dela e o camarada também agradava com o que fosse colhido porque a terra era dela”.

Sr. Quinca, pescador.

Aspectos semelhantes foram observados por Moura \& Teixeira (1993) na Lagoa do Piató, em Assu, Rio Grande do Norte. Nessa localidade, algumas comunidades que compõem o complexo do Piató também possuíam essa característica de subsistência com base na pesca e na agricultura. Os moradores estavam sustentados por uma lógica da estrutura fundiária bastante distinta da atual. Devido às pressões externas, exercidas pela implantação da agroindústria ao longo do vale do rio Assu, os territórios antes utilizados para o plantio familiar passaram a ser alvo da iniciativa privada, e aos poucos

\footnotetext{
${ }^{10}$ Conforme Barreto (1985, p.55), Luiz José Gomes (Lula Gomes) foi administrador do município nos períodos de 1924 a 1928 e 1928 a 1930.
} 
a população foi perdendo seus territórios e rompendo com essa forma associada de produção de subsistência.

No Canto do Mangue, a mudança na estrutura fundiária alterou positivamente a vida dos proprietários de terra. Antes, essas áreas eram praticamente improdutivas; com a introdução da carcinicultura, passaram a ser supervalorizadas economicamente, contribuindo para a recuperação financeira dos proprietários.

Em contrapartida, para os moradores do Canto do Mangue essa mudança não foi favorável, visto que, para venda ou arrendamento das terras próximas à comunidade, aos criadores de camarão, os proprietários tiveram que se desfazer das antigas parcerias estabelecidas com os moradores locais. Estes acabaram ficando sem uma fonte complementar de alimentação, passando a comprar os produtos que outrora cultivavam.

Alguns pescadores chegavam a construir pequenos viveiros nessa área, nos quais deixavam uma certa quantidade de peixe (criados em cativeiro) e despescavam em períodos de alta do pescado no mercado local, como na "semana santa" (na páscoa), época de grande procura de peixe pelas pessoas que se abstêm do consumo de carnes vermelhas.

"Aqui se vê viveiro de camarão por todo canto. Aqueles terrenos que eram de Dona Iara, agora todos são tanque. Vêm da Rua do Quadro, no Canto do Mangue, até aqui na Rua do Porto. Arrendaram esses terrenos todos, ou foram vendidos todos para se criar camarão. Só se fala mesmo é no camarão. Até os chocadores [viveiros] de Capiba [Sr. Capiba é um antigo pescador do local] que eram em terras de Mozart ${ }^{11}$ [falecido proprietário de terras do município] acabaram todos. A família de Mozart pediu que ele deixasse o terreno. E veja que ele estava ali há mais de quarenta

${ }^{11}$ De acordo com Barreto (1985, p. 55), Mozart Callafange foi nomeado prefeito de Canguaretama no período de 1952 a 1953. 
anos. Agora essas terras foram colocadas na justiça pelos herdeiros".

Raimundo, pescador.

Já em relação aos recursos fornecidos pelos manguezais, a população reclamou da escassez de peixes, crustáceos e moluscos, chegando a atribuir a redução do estoque pesqueiro à acelerada degradação dos manguezais nos últimos anos.

"Minha filha, quando eu vim morar em Canguaretama as coisas eram diferentes de agora. Eu morei perto dos pescadores $e$ naquele tempo tinha pescarias fartas, o peixe era farto. As coisas agora parecem limitadas, naquele tempo não tinha o camarão [refere-se á carcinicultura]. Existia quem pescasse o camarão na maré, mas não era como agora com esses viveiros. Essa gente que vem de fora para arrendar a terra, comprar os terrenos e fazer viveiros, não tinha. Tinha sim, a pescaria do camarão como toda vida houve. Mesmo porque aqueles pescadores que pegavam o camarão já tinham para quem vender o pescado, como Nilo de Marlúcia. Ele comprava o camarão dos pescadores e depois torrava [cozia] para vender o camarão já torrado nas feiras dessas cidades por perto".

Maria Julia, moradora local.

Além disso, eles queixaram-se das mudanças ocorridas nas rotas percorridas até os seus pontos de pesca. Com as instalações dos tanques, muitos caminhos foram fechados, deixando de dar acesso às canoas.

"Aqui tem muita coisa para falar. Para você ter uma idéia eu tenho um problema grande com esse corte de mangue. Estão cortando muito mangue! O nosso manguezal está sendo destruído! 
Todos os caminhos eles [os empresários] estão interditando. Aí é um problema em cima de outro problema. Estão interditando os caminhos por onde possam os pescadores. E eu meto a bronca, porque essa construção de viveiros a todo o momento está acabando com a passagem dos pescadores. Eles compraram as propriedades, mas o caminho eles não compraram. As rotas dos pescadores estão ficando bloqueadas. Isso é para a ver o que o dinheiro faz. O dinheiro fala mais alto!".

Luiz Marques, ex-presidente da Colônia de Pescadores.

As Figuras 9 e 10 a seguir apresentam a configuração do espaço local no rio Pituassu, no qual encontra-se embargada pelo IDEMA a obra de instalação de tanques de cultivo nas proximidades do Canto do Mangue, no trecho do referido rio que a população local denomina de rio do Martelo.

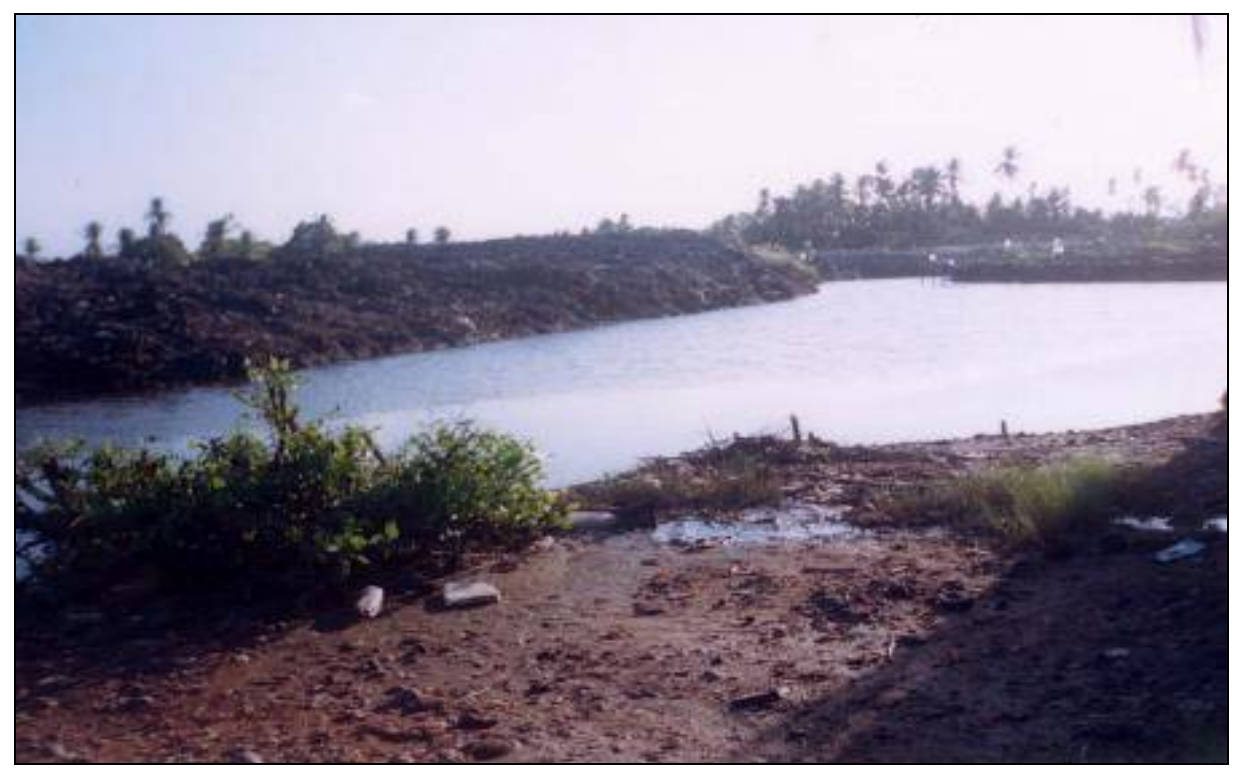

Figura 9 - Vista do Pituassu, Canto do Mangue, fev., 2004 


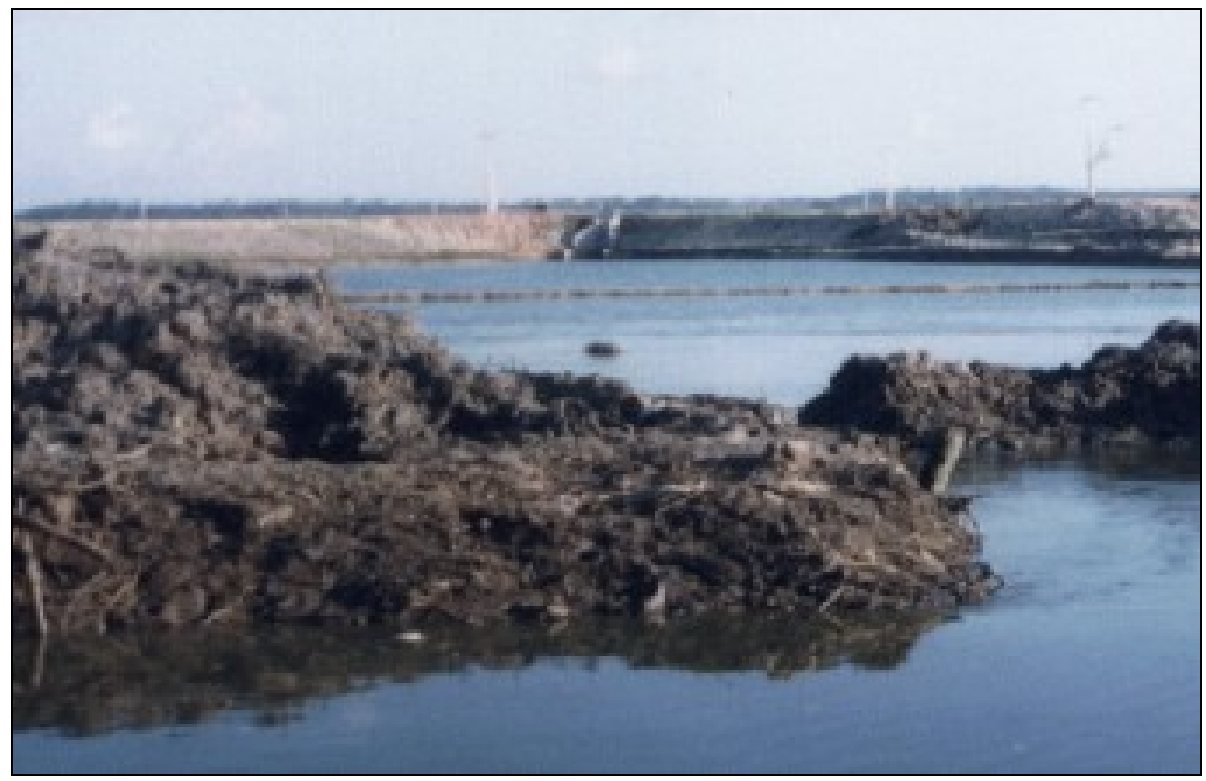

Figura 10 - Tanques instalados no Pituassu, fev., 2004

O fenômeno territorial ampliado por peculiaridades humanas conduz a desconexões e conseqüentemente a rearranjos, os quais decorrem da escassez dos recursos naturais, até mesmo da proibição do acesso aos mesmos (Marques, 2001). Na realidade, essas mudanças do local são ditadas por peculiaridades estabelecidas pelos "novos donos da terra".

A compra das áreas estuarinas por empresas de camarão tem dificultado o uso comum dos recursos pesqueiros. A expansão do capital nessa região deixa indagações difíceis de responder. Seria possível nessa transição de posse do território o uso sustentável dos recursos que contemplasse a todos os atores sociais envolvidos no processo de transformação territorial? Seria também possível respeitar os elementos inclusos na premissa de sustentabilidade?

Considerando que o desenvolvimento sustentável serve de parâmetro teórico para a implantação da carcinicultura em diversos países do mundo, incluindo o Brasil, fica evidenciado, com base nos relatos anteriores dos moradores, o desafio de vincular teoria e prática, elementos essenciais na abordagem do desenvolvimento sustentável, conforme Leff (2001) e Sachs (1998b). 
Esse último autor chega a afirmar que o desafio é mobilizar o potencial científico e tecnológico instalado no Brasil e em outros países, tendo em vista desenvolver para proteger, desenvolver protegendo, desenvolver de maneira a aproveitar o potencial dos recursos renováveis para fins socialmente legítimos, mantendo ao mesmo tempo a integridade do capital da natureza (Sachs, 1998b).

O Plano de Desenvolvimento Sustentável para Carcinicultura (Rio Grande do Norte, 2001) apresenta uma elogiável proposta em termos teóricos. Contudo, o desafio de aplicar teoria e prática (no estuário do Curimataú/Cunhaú) descrita nesse documento ainda encontra-se distante da realidade do que realmente propõe o desenvolvimento sustentável. Ou seja, conciliar eficiência econômica, justiça social e prudência ecológica e ambiental.

Nas palavras de Sachs (ibid., p. 58) "não é possível existir desenvolvimento sustentável numa economia de mercado, no sentido pleno do termo". No entanto, é possível, ao meu ver, se pensar em criar condições que possibilitem o desenvolvimento da carcinicultura de forma menos impactante no Rio Grande do Norte.

Para isso, são necessárias ações políticas favoráveis aos planos de manejo e conservação dos recursos disponíveis nos estuários atualmente ocupados pala carcinicultura, permitindo também o gerenciamento participativo desses recursos de forma a contemplar a população local.

Atualmente o que pode ser observado no estuário do Curimataú/Cunhaú, com base no referencial apresentado por Galvão (2000); Silva (2000); Melo Júnior (2003, 2001, 2000), e Silva \& Garavello (2003a, 2003b), encontra-se distante dessa proposta. O que de fato pode-se verificar, com base nos documentos pesquisados, nas entrevistas com os moradores do Canto do Mangue e nas observações realizadas no campo, é a viabilidade econômica da atividade, com expressiva produtividade e a geração de divisas que deveriam ser aplicadas também na melhoria das condições de vida daqueles que estão perdendo os seus territórios de (re)produção e sofrendo os efeitos predatórios da atividade. 


\subsection{Saberes relacionados à pesca artesanal}

O conhecimento tradicional dos pescadores artesanais não é pré-lógico ou précientífico, mas, como afirma Lévi-Strauss (1989), ele é baseado em observações contínuas de fenômenos naturais recorrentes que permitem ao pescador tomar decisões sobre o momento de ir à pesca, o local mais adequado para a captura e o uso de técnicas mais apropriadas. Sem esse conhecimento não seria possível a sobrevivência dessas comunidades e a reprodução do seu modo de vida no ambiente costeiro, sujeito a freqüentes mudanças.

\section{Técnicas e locais de captura}

$\mathrm{Na}$ captura, os pescadores do Canto do Mangue utilizam aparelhos de pesca como rede de tapagem, tarrafa, tainheira, rede de espera (também chamada malhadeira), arrasto, entre outros. A tarrafa (Figura 11) e a tainheira são utilizadas em diversas comunidades pesqueiras do Nordeste, como menciona Cardoso (2001). Já a rede de espera é bastante utilizada, como observaram Ramires \& Barrella, (2003), nas comunidades de Barra do Una e Guaraú, no município de Peruíbe - SP.

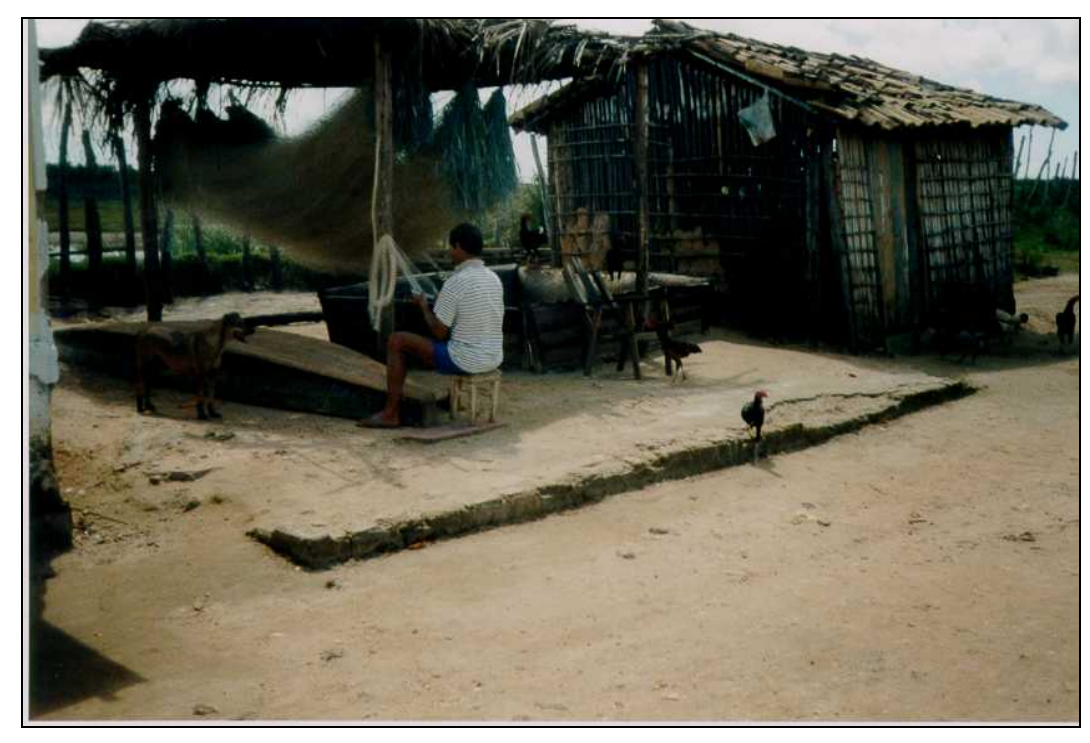

Figura 11 - Pescador confeccionando tarrafa, fev,. 2003 
Devido à fragilidade e ao tamanho das embarcações, são poucos pescadores que praticam a pesca no "mar de fora", ou alto-mar. A maioria dos entrevistados utiliza a canoa a remo ou a motor como forma de locomoção, como apresenta a Figura 12. Na captura, os pescadores do Canto do Mangue exploram com mais freqüência o estuário do Curimataú/Cunhaú e áreas de manguezais adjacentes.

A canoa é o tipo de embarcação mais utilizada por todas as comunidades pesqueiras de Canguaretama: Canto do Mangue, Rua do Porto, Lagoa de São João e Barra de Cunhaú. No Canto do Mangue, as mulheres normalmente utilizam canoas a remo na coleta de marisco, enquanto os homens utilizam canoas a motor nas suas pescarias. A diferenciação pode ser compreendida devido aos locais de captura: para os homens, os pontos são mais distantes; já para as mulheres, são mais próximos, visto que a coleta dos moluscos ocorre nos manguezais e nas "croas"12. Os catadores de caranguejos também utilizam canoas a remo por ser o manguezal o seu local de trabalho.

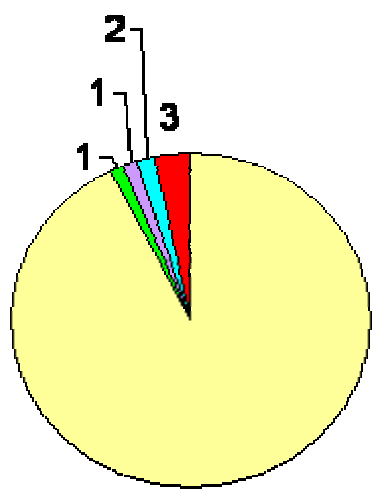

83

\begin{tabular}{|lll|}
\hline$\square$ Canoa & $\square$ Jangada & $\square$ Paqueta \\
$\square$ Bote a Vela & $\square$ Bote a Motor & \\
\hline
\end{tabular}

Figura 12 - Distribuição dos tipos de embarcações em percentagem (\%), utilizadas em Canguaretama - 1993 a 2002

Fonte: IBAMA/CEPENE (1993 a 2002).

\footnotetext{
${ }^{12}$ De acordo com Mourão (2000), as "croas", reconhecidas pelos pescadores, são bancos de areia e lama que afloram na baixa-mar, correspondendo aos depósitos aluviais na tipologia científica; várias espécies habitam esses lugares, ou simplesmente os visitam à procura de alimentos.
} 
A constatação de que 93\% das embarcações são canoas (Figura 12) reforça a suposição da pesca no município ser uma atividade de subsistência que contribui para a sobrevivência de uma parcela de menor poder aquisitivo da população do município, o que é de fundamental importância.

Em relação aos locais de captura de pescado, essa é uma característica que sofre variação de comunidade para comunidade. Estudo realizado por Clauzet (2003), na Enseada do Mar Virado, em Ubatuba - SP, constatou que os pescadores locais utilizam três pontos diferentes na captura: a baía da enseada, as imediações da Ilha do Mar Virado e a região marítima costeira, sendo que os métodos de captura e as embarcações utilizadas são escolhidos de acordo com os locais de pesca.

Segundo os pescadores do Canto do Mangue, o "Meral"13 é um dos melhores pontos de pesca, mesmo sendo citados outros pontos como a Casqueira e o Francês (pesqueiros). Nas proximidades desses pontos, os pescadores dispõem de locais de apoio, chamados de "barracas", nas quais ficam guardados os apetrechos de pesca.

"Eu mesmo pesco por aqui. Agora a gente vai para dentro também, lá pelo Merá [Meral]. Para chegar à barraca que fica do outro lado do rio, somente de barco, ou canoa na maré baixa. A gente leva uma hora ou duas, para chegar, isso depende da maré".

Pedro, pescador.

É importante destacar que "as barracas" são de uso comum. Todos os pescadores de Canguaretama podem utilizar a estrutura de apoio, devendo deixar os pertences da mesma maneira que foram encontrados. São normas de conduta que viabilizam uma melhor convivência entre os membros do grupo. No entanto, durante as visitas realizadas ao Canto do Mangue foi possível observar que existe um conflito relacionado ao uso dessas estruturas de apoio, quando pescadores de outras localidades

${ }^{13}$ Denominação atribuída ao local de encontro das águas dos rios que compõem o estuário do Rio Curimataú, em virtude da grande quantidade de peixe mero encontrado no local. 
vêm praticar a pesca nas proximidades do Meral, Casqueira e do Francês, locais de pesca nos quais os pescadores do Canto do Mangue realizam as suas pescarias.

"Aqui todo mudo usa as barracas, cada qual leva uma coisa que vai precisar e deixa lá, panela, lampião, querosene, essa coisa. Deixa por lá e ninguém mexe. Agora quando vem assim, um pescador de fora, vem muito uns da Paraíba, de Rio Tinto, aí mexem e deixam tudo virado, já chegou até a desaparecer coisa das barracas”.

Quinca, pescador.

Autores como Begossi et. al. (2002); Castro \& Begossi (1995) e Marques (2001), entre outros, registram que as comunidades pesqueiras de diversas partes do mundo mantêm direitos de posse sobre áreas próximas às costas oceânicas. De acordo com Costa Neto \& Marques (2001), os pescadores de Siribinha, litoral norte da Bahia, afirmam que não existem lugares específicos para a pesca. Entretanto, a observação comportamental das práticas pesqueiras demonstrou a existência de certos locais, como os "pesqueiros" (recifes artificiais) e áreas de pesca, mantidos sob o conhecimento de poucos pescadores.

Esse fato pode ser uma estratégia de manter em sigilo os locais de maior abundância de pescado para assim, maximizar a captura. Porém, existem outras variáveis importantes associadas ao conhecimento desses locais, sobretudo, físicas e meteorológicas que influem na captura, como níveis da maré (baixa-mar a preamar influenciadas pelas fases da lua), as condições do tempo (chuva, sol, direção dos ventos), a predominância das correntes fluviais e marítimas, entre outros elementos, incluindo fatores subjetivos que necessitam de uma análise aprofundada, conforme o relato abaixo.

"Olhe moça se o pescador soubesse mesmo onde está o peixe não existia pescador pobre (...) O peixe é como gente, nunca está parado, assim dizer que o camarada sabe onde ele está de fato é 
meio difícil. Mas não vou dizer que a gente não tem idéia de onde encontrar mais peixe. Isso a gente tem sim, porque já está acostumado ir todos dias para esses cantos. Mas também, depende do dia, se a maré está alta, baixa, o vento como está, aí a gente sabe o que vai pegar o tipo de pescaria que é melhor, também tem a sorte, se Deus dar a sorte, aí tem peixe!”.

Quinca, pescador.

O estuário do rio Curimataú/Cunhaú (Figuras 13 e 14) se constitui num local de grande importância para os pescadores do Canto do Mangue e de outras comunidades pesqueiras do município, pois nele estão localizados importantes pesqueiros que são favorecidos pela reserva de manguezal dessa área.

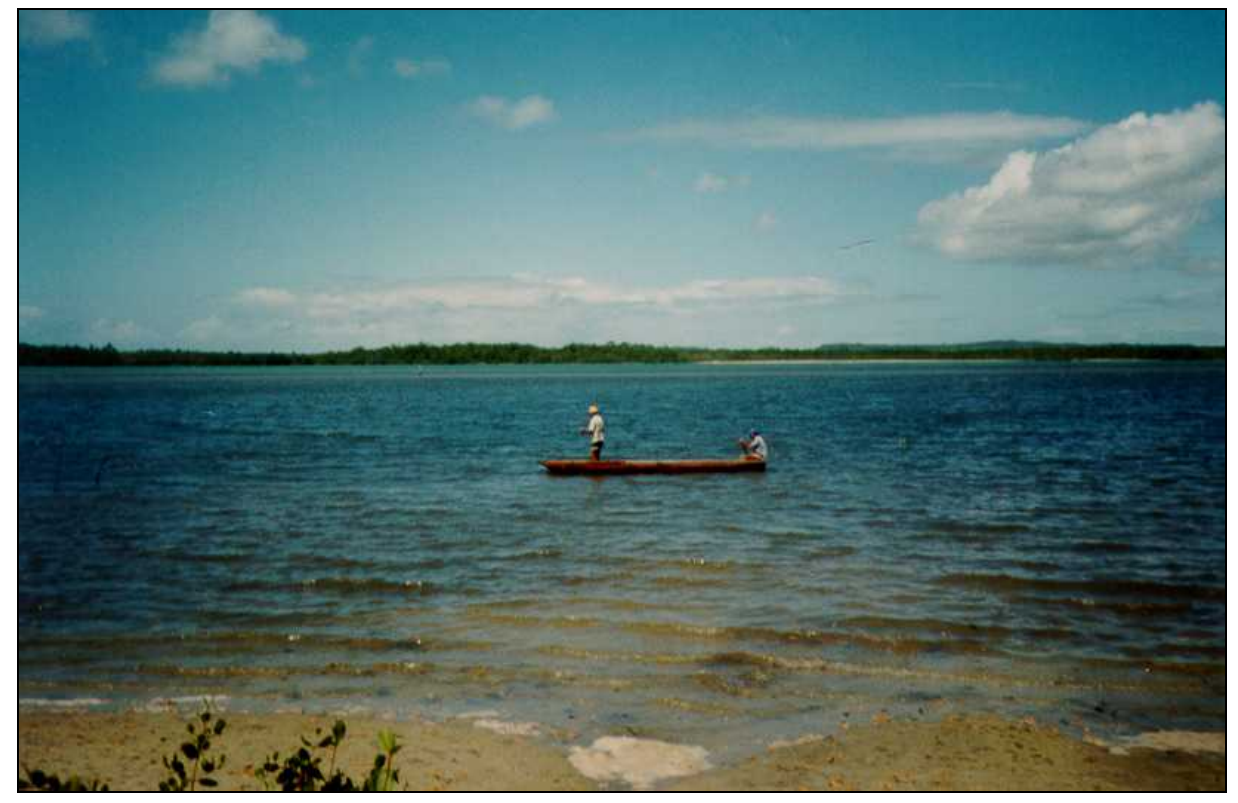

Figura 13 - Estuário do rio Curimataú/Cunhaú, fev., 2003 


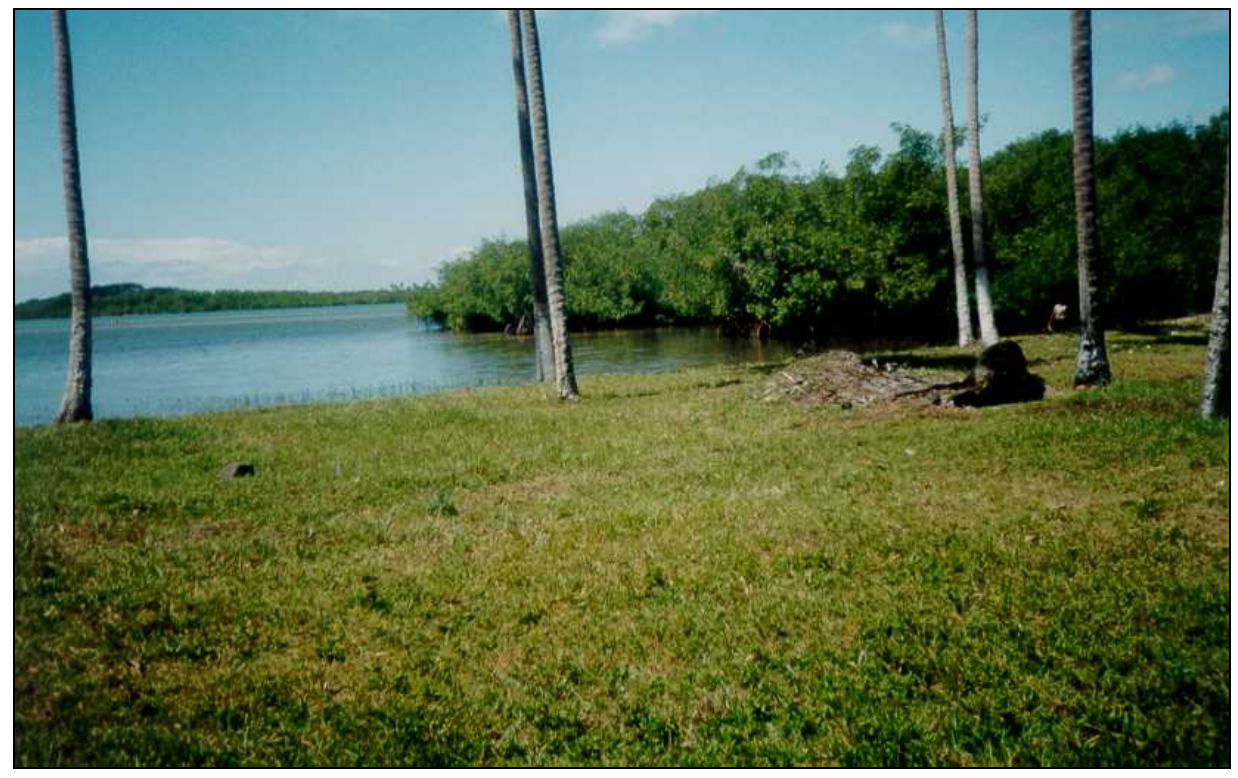

Figura 14 - Estuário do rio Curimataú/Cunhaú, com vista para o manguezal, fev., 2003

Estudo realizado por Diegues (2001) em Galinhos, litoral do Rio Grande do Norte, estabelece que, quando um pescador se dispõe a indicar a localização das rochas submersas (os pesqueiros), espera que o seu companheiro de pescaria, em geral filho ou sobrinho, demonstre interesse por partilhar com ele esse conhecimento. Sendo o conhecimento dos locais privilegiados de pesca (os "pesqueiros") guardada pelos os mais experientes, esse se constitui em um acervo de grande importância, e a localização desses pontos é transmitida oralmente pelos "mais antigos".

Dessa forma, a importância do conhecimento dos "especialistas da tradição", conforme a expressão de Allut (2000), torna-se indispensável na utilização dos recursos, e a sua forma de manejo vem permitindo a manutenção da qualidade ambiental e contribuindo para a conservação dos recursos pesqueiros. 


\section{Espécies capturas no Canto do Mangue}

A diversidade de peixes, crustáceos e moluscos capturados por pescadores do Canto do Mangue é ampla. Por meio das observações realizadas na comunidade, pude verificar que as espécies mencionadas são aquelas cujo valor comercial é mais elevado.

Existe por parte dos pescadores uma seleção comercial entre espécies que eles chamam de "primeira" e as que chamam de "segunda". Normalmente, as espécies de "primeira" são aquelas mais procuradas comercialmente; já as de "segunda" são as que no geral ficam para o consumo familiar e(ou) para serem doadas aos membros da comunidade.

Nas visitas ao Canto do Mangue, pude observar mulheres preparando espécies de peixes que quase não são comercializadas. Observações semelhantes foram realizadas nas comunidades pesqueiras do complexo lagunar do Piató, no Rio Grande do Norte, por Moura \& Teixeira (1993).

Além do sentido utilitário, essa classificação possui um sentido simbólico, que expressa as condições financeiras do pescador no momento. O peixe de "segunda“ é consumido "por quem está enfrentando dificuldades, na falta do dinheiro se come tudo", nas palavras de Tonha, marisqueira.

Outros elementos de suma importância também podem ser considerados na omissão de espécies pelos pescadores. Por exemplo, o fato de o pescado ser ou não "carregado" - "pescado que não pode ser consumido por pessoas que apresentam determinadas enfermidades ou que estão em repouso, como as mulheres no período pósparto" (Silva, 1999).

Com base nessas constatações, falar de diversidade de espécies conhecidas por pescadores é uma análise que vai além do que o pescador menciona. Não tendo a pretensão de desconsiderar a amplitude do conhecimento dessa população, são apresentadas a seguir, na Tabela 3, as espécies que foram citadas pelos pescadores entrevistados no Canto do Mangue. 
Tabela 3. Espécies capturadas na comunidade do Canto do Mangue ${ }^{14}$

\begin{tabular}{|c|c|c|c|c|c|}
\hline \multicolumn{2}{|c|}{ Peixes } & \multicolumn{2}{|c|}{ Crustáceos } & \multicolumn{2}{|c|}{ Moluscos } \\
\hline $\begin{array}{c}\text { Denominação } \\
\text { local }\end{array}$ & $\begin{array}{c}\text { Denominação } \\
\text { científica }\end{array}$ & $\begin{array}{c}\text { Denominação } \\
\text { local }\end{array}$ & $\begin{array}{c}\text { Denominação } \\
\text { científica }\end{array}$ & $\begin{array}{c}\text { Denominação } \\
\text { local }\end{array}$ & $\begin{array}{c}\text { Denominação } \\
\text { científica }\end{array}$ \\
\hline Camurim & Centropomus sp. & $\begin{array}{l}\text { Caranguejo- } \\
\text { úça }\end{array}$ & Ucides cardatus & Sururu & Mytilus falceta \\
\hline Carapeba & $\begin{array}{c}\text { Eugerres } \\
\text { brasilianus }\end{array}$ & Aratu & $\begin{array}{c}\text { Goniopsis } \\
\text { crentata }\end{array}$ & Marisco & $\begin{array}{c}\text { Anamalocardia } \\
\text { brasiliana }\end{array}$ \\
\hline Tainha & Mugil sp. & $\begin{array}{c}\text { Camarão } \\
\text { (nativo) }\end{array}$ & PENAEIDAE & Ostra & Crassostrea $s p$ \\
\hline Mero & $\begin{array}{l}\text { Promicrops } \\
\text { itajara }\end{array}$ & $\begin{array}{l}\text { Caranguejo } \\
\text { Goiamum }\end{array}$ & $\begin{array}{l}\text { Cardisoma } \\
\text { guainhumi }\end{array}$ & Unha de Velho & $\begin{array}{l}\text { Tagellus } \\
\text { plebeius }\end{array}$ \\
\hline Agulha & $\begin{array}{c}\text { Hemirhamphus } \\
\text { basiliensis }\end{array}$ & Siri & Callinectes ssp. & & \\
\hline $\begin{array}{l}\text { Arraia } \\
\text { Bagre }\end{array}$ & $\begin{array}{l}\text { Rhinobatos spp } \\
\text { AIIDAE }\end{array}$ & & & & \\
\hline Pescada & Cynoscion sp. & & & & \\
\hline Camurupim & Tarpon atlanticus & & & & \\
\hline $\begin{array}{l}\text { Urubaiana } \\
\text { Manjuba }\end{array}$ & ENGRAULIDAE & & & & \\
\hline
\end{tabular}

Fonte: pesquisa de campo, 2003.

As espécies citadas são capturadas nos estuários e nas “croas”. Em estudo realizado no estuário do rio Mamanguape, Paraíba Mourão (2000) menciona que esses pontos de captura são bastante freqüentados por pescadores.

Entre as espécies de pescado ${ }^{15}$ que mais têm contribuído nos últimos dez anos na produção pesqueira de Canguaretama estão a tainha 19\%, e o caranguejo-uçá 55\%, como apresenta a Figura 15. Juntas, essas espécies representam $74 \%$ da produção de pescado do município.

\footnotetext{
${ }^{14}$ Nomes científicos (família, gênero ou espécie) obtidos em CEPENE, 2001, sem identificação por parte da pesquisadora.

${ }^{15}$ Os dados obtidos no CEPENE/IBAMA referem-se à produção de recursos pesqueiros como produção de pescado, no qual incluindo peixes, crustáceos e moluscos.
} 


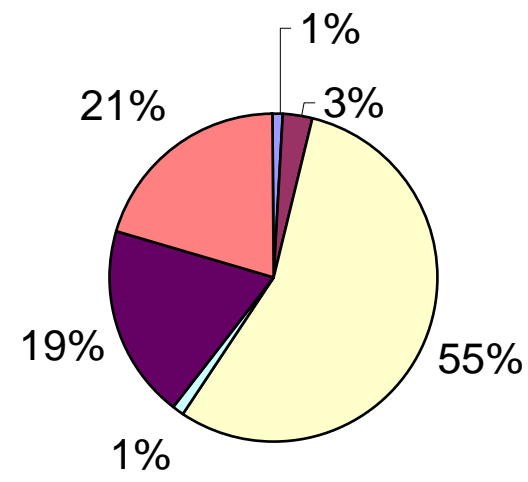

\begin{tabular}{|c|c|}
\hline$\square$ Bagre & $\square$ Camarão Nativo $\square$ Caranguejo \\
\hline$\square$ Serra & $\square$ Tainha \\
\hline
\end{tabular}

Figura 15 - Contribuição média por espécie em Canguaretama de 1993 a 2002 Fonte: IBAMA e CEPENE, 1993 a 2002.

\section{Observações sobre a reprodução}

A reprodução de espécies conhecidas por pescadores do Canto do Mangue é variada e envolve processos abrangentes. Assim, optei por destacar as observações dos moradores em relação ao caranguejo-uçá, por ser a espécie de maior contribuição na produção pesqueira do município: 55\%. A coleta desse crustáceo caracteriza-se como uma atividade fundamentalmente masculina na comunidade; todavia, nas "épocas de andada", as mulheres também realizam coletas, sobretudo, para o consumo familiar.

"Em janeiro era grande a quantidade de caranguejo por aqui e até mulher pegava se carecesse. Agora o caranguejo está bem pouco. Fala-se que o camarão [a carcinicultura] está acabando com o caranguejo. Teve um tempo desses que eles apareciam já mortos. Ou às vezes já mole [agonizando], aí levaram eles [os 
caranguejos] para São Paulo e até hoje ninguém daqui ficou sabendo o que aconteceu. Nos meses de janeiro e fevereiro aqui não se pega 'as ovadas' [as fêmeas], somente machos”.

Tânia, marisqueira.

A época da reprodução do caranguejo-uçá é caracterizada pela saída dos indivíduos de suas tocas em grandes quantidades, para se deslocarem na área de mangue, distanciando-se bastante de suas galerias. Os catadores chamam esse fenômeno de “andada" do caranguejo (Nordi, 1994).

Pinheiro et. al. (2003) mencionam que o ciclo reprodutivo dessa espécie estende-se de outubro a março. Nesse período, ocorre o acasalamento e a desova. Durante a "andada", os animais são facilmente capturados por se tornarem mais expostos à ação dos catadores. No entanto, muitos catadores compreendem a importância de considerar certos cuidados na captura durante esse período.

"Sabemos que o caranguejo sai do seu buraco na andada para ali se reproduzir. Ficam tontos e caminham para cima e para baixo à procura do seu par. Agora que fica fácil de pegar, isso fica porque eles não correm. Isso dura quase uma semana. O certo é se o caranguejo for pego nesse tempo ele não terá filhotes, vai acabando aos pouquinhos”.

Zé Antônio, pescador.

Durante as visitas à comunidade foi possível registrar, em conversas informais, uma forma distinta de entendimento do ciclo reprodutivo dessa espécie, por parte dos moradores, realizada como base no calendário anual. Segundo os moradores locais, os meses do ano que possuem a letra "R" na sua grafia (setembro, outubro, novembro, dezembro, janeiro, fevereiro, março e abril) correspondem ao período de engorda do caranguejo, sendo janeiro o mês no qual o caranguejo encontra-se mais gordo, ou pronto para acasalar. 
Enquanto que os meses que não contêm a letra "R" na grafia (maio, junho, julho e agosto) correspondem ao período do caranguejo magro. A engorda atribuída à espécie nos oito meses grafados com a letra "R" está associada ao período de reprodução, sendo janeiro o mês no qual as fêmeas apresentam-se ovígeras.

As observações sobre a reprodução desse crustáceo são elaboradas com critérios que obedecem e ultrapassam a época de reprodução, de acordo a literatura científica vista em Pinheiro et. al. (2003), deixando uma margem de antecedência e procedência de um mês para o período de reprodução em relação à literatura cientifica.

Ainda é possível observar que esse intervalo de tempo aproxima-se do defeso estabelecido pelo IBAMA, cuja extensão vai de 01 de dezembro até 31 de maio nos Estados do Nordeste e no Pará. Essas constatações apontam para a existência de um conhecimento elaborado cujas práticas de manejo favorecem a conservação desse recurso.

O caranguejo-uçá é uma espécie muito explorada e atualmente vem sofrendo a ação predatória por parte dos catadores. Diegues \& Nogara (1999) comentam que em Magé, Rio de Janeiro, segundo relato de moradores do Saco de Mamanguá, os catadores colocam armadilhas em inúmeras tocas e escavam muitos buracos de grandes dimensões para coletarem os caranguejos na "andada”, prática considerada predatória.

De acordo com Nordi (1994), a intensificação da coleta no período de "andada" é reconhecidamente prejudicial à preservação da espécie. Tal procedimento pode estar sendo influenciado por fatores que não são compreensíveis à luz dos preceitos ecológicos, já que o incremento da população freqüentadora do mangue na época de captura pode ser explicado pelo aumento de mulheres e crianças na captura do crustáceo durante a "andada".

No Canto do Mangue esse fato também foi observado, podendo ser analisado sob a ótica econômica. O incremento do turismo nas cidades litorâneas do Estado nessa época do ano, por exemplo, aumenta consideravelmente. Com isso, a procura por peixes, crustáceos e moluscos tendem a aumentar.

A procura por um determinado produto no âmbito de uma economia de mercado ocasiona a alta dos preços. Assim, diversas espécies, inclusive o caranguejo, 
nesse período, passam a possuir maior valor comercial e a captura tende a se intensificar, devido ao fato de atrair parte da população que não pratica a captura de caranguejo como principal atividade econômica.

É exatamente durante o período de reprodução, que se dá a alta no preço desse crustáceo, e é também o período em que ele é mais apreciado, segundo Joaquim, catador de caranguejo na comunidade "caranguejo magro não tem gosto e ninguém quer comprar”. Assim, muitas vezes ocorre uma dicotomia entre o conhecimento dos catadores e prática relacionada à conservação.

$\mathrm{Na}$ comunidade, os entrevistados não assumiram praticar a captura durante o defeso, mas alegaram existir essa captura por parte dos que não são caranguejeiros profissionais. Nessa direção, Marques (1999) menciona que cada cultura é um processo com dinamismo próprio, complexidade variável e, por muitas vezes do ponto de vista do desenvolvimento apresentam insustentabilidades, sendo importante assim, estabelecer um dialogo entre a ciência e esse conhecimento para propor alternativas, e ou considerálo, quando possível.

Os catadores sazonais, segundo os moradores do Canto do Mangue, desrespeitam as normas estabelecidas pelo IBAMA e tendem a maximizar suas produções.

O cara que vive do caranguejo sabe que tem que cuidar (...) Mas, quando aumenta o preço, por causa da venda nesses restaurantes, no verão, todo mundo cresce o olho e quer pegar caranguejo. Aí já viu! Eles pegam de todo tamanho, com ova e sem ova [machos ou fêmeas].

José Campos, pescador aposentado.

Atualmente, os órgãos de fiscalização têm apresentado um grande avanço na proteção desse período e na proibição da utilização de armadilhas e produtos químicos para a captura de caranguejos. As portarias de proteção jurídica têm estipulado o período 
de defeso, tamanho mínimo de captura, proibição da coleta de fêmeas ovígeras e uso de armadilhas. $^{16}$

Mas a capacidade de lidar com o ambiente sem predar os seus recursos e o conhecimento dos pescadores são relegados ao plano inferior, na medida em que o uso dos recursos é decidido e administrado praticamente sem a participação dessa categoria. Nesse sentido, retomo as palavras de Allut (2000) quando afirma que a credibilidade social do conhecimento do pescador torna-se afetada pelo que o pescador é em relação a os seus interlocutores, ficando o conhecimento da tradição às margens do conhecimento científico.

Conforme Almeida (2002b) e Balandier (1997), esse saber se constitui num rico e diversificado marco de leitura e interpretação, sendo a soma de saberes acumulados pela coletividade a partir de acontecimento e princípios fundadores. Sendo necessário o diálogo entre essas duas formas de conhecer o mundo. É, portanto, necessário considerar os saberes dos pescadores na elaboração de leis que regulamentem o gerenciamento dos recursos pesqueiros. Um outro fator que, segundo a população, tem contribuído para o desaparecimento dessa e de outras espécies na área estudada, é a carcinicultura.

“Da 'boca da barra' [estuário do rio Curimaú/Curimataú] para cá [Canto do Mangue] só têm viveiros. Agora eu penso que os caranguejos devem ter acabado também devido o remédio que eles colocam nos viveiros. Colocam para matar as ovas [larvas] do caranguejo e de peixes, como o camurim que come o camarão. Aquilo quando eles tiram o camarão [despesca] e jogam as águas dos viveiros de volta nos mangues matam tudo. É por isso que o caranguejo daqui está acabando”.

José Campos, pescador aposentado.

\footnotetext{
${ }^{16}$ O período de defeso do caranguejo-uçá (Ucides cordatus) nos nove Estados do Nordeste brasileiro e no Pará vai de 01 de dezembro a 31 de maio de 2004, sendo proibido capturar, manter em cativeiro, transportar, beneficiar, industrializar e comercializar as fêmeas do caranguejo. A proibição da cata do crustáceo foi regulamentada pela portaria $n^{\circ} 34$, de 24 de junho de 2003. Essa portaria aumentou de 4,5 centímetros para 6 centímetros a largura mínima da carapaça do caranguejo-uçá (fêmeas e machos) permitida para coleta. Disponível em: http//www.ibama.gov.br - acesso em 23 de jan. 2004.
} 
De acordo com Coelho Júnior e Schaeffer-Novelli (2000), diversas espécies de importância econômica utilizam os estuários margeados por manguezais para reprodução ou para desenvolvimento de estágios de seus ciclos de vida. Estima-se que 60 a 70\% do pescado da costa brasileira sejam organismos que utilizam os estuários e manguezais pelo menos em uma fase do seu desenvolvimento, daí a preocupação com a sustentabilidade desse ecossistema.

Estudos realizados por Souza \& Barrella (2001) em Barra do Una e Guaraú, no município de Peruíbe - SP, destacam a importância da observação dos pescadores em relação ao conhecimento ecológico relacionado a hábitat, reprodução, alimentação, comportamento e morfologia das espécies de mais representatividade econômica, visto que a reprodução dessas populações está diretamente relacionada ao conhecimento dos recursos que utilizam.

Alves \& Nishida (2002) registram o conhecimento da população que sobrevive da coleta do caranguejo-uçá no estuário do rio Mamanguape na Paraíba, em relação ao processo de ecdise (que envolve a muda do exoesqueleto). Os autores mencionam ainda o fato de a observação das espécies de interesse dessas populações estar diretamente relacionada à sobrevivência do grupo, e que o uso dos recursos está embasado num conjunto de conhecimentos e práticas que Lévi-Strauss (1989) denomina de "ciência do concreto".

Em Canguaretama, a escassez dos caranguejos vem sendo um assunto bastante polêmico, pois afeta a vida daqueles que não dispõem de outros ofícios para adquirirem seu sustento diário. A pesca predatória associada à falta de uma fiscalização efetiva, a degradação dos manguezais e o desrespeito às leis ambientais são fatores que têm favorecido a redução acentuada das populações de caranguejo-uçá nos últimos anos. Esse tema voltará a ser discutido neste trabalho no item 5.5. 


\title{
4.3 O modo de vida no espaço local
}

\section{Condições de moradia}

\begin{abstract}
"A casa em que nasci tinha ao lado um grande viveiro de peixes, de caranguejos $e$ de siris, se não nasci mesmo dentro do viveiro, como os caranguejos, já com dois anos estava dentro dele (...) Foi com essas sombrias imagens dos mangues e da lama que comecei a criar o mundo da minha infância”.
\end{abstract}

Josué de Castro

Toda mudança traz consigo aspectos positivos e negativos para a vida dos atores sociais envolvidos no processo de (re)produção e transformação espacial. Há aproximadamente duas décadas, as casas dos pescadores do Canto do Mangue eram, em sua maioria, "construídas com estrutura de madeira de mangue, preenchidas com barro coletado nas margens da maré e de chão batido, algumas até chegavam a ser cobertas com palhas de coqueiro, poucas eram de alvenaria" (Quaresma, 1987, p. 8).

Estudo realizado por Quaresma (1987) menciona a precariedade dos locais de moradia dessa população, que residem em verdadeiros cubículos construídos em terrenos alagados às margens da maré. As condições de moradia dos pescadores do Canto do Mangue se assemelhavam às condições de pescadores de outras localidades, como por exemplo, as comunidades situadas às margens do Canal de Santa Cruz, em Pernambuco. Lima \& Quinamo (2000) constataram que, em sua maioria, os habitantes não dispõem de coleta regular de lixo, abastecimento diário de água e possuem moradias precárias.

No Canto do Mangue a maioria das residências se localizava em áreas de risco, próximas ao fluxo da maré, sofrendo enchentes nas grandes marés ou no período de inverno, quando se torna maior a descarga fluvial e pluvial. As condições de moradia e higiene eram bastante precárias. Um fato comum era o lixo da cidade ser depositado nas adjacências dos manguezais. Essa prática ainda pode ser observada, pois em determinados pontos da comunidade encontram-se lixões a céu-aberto (Figura 16). 


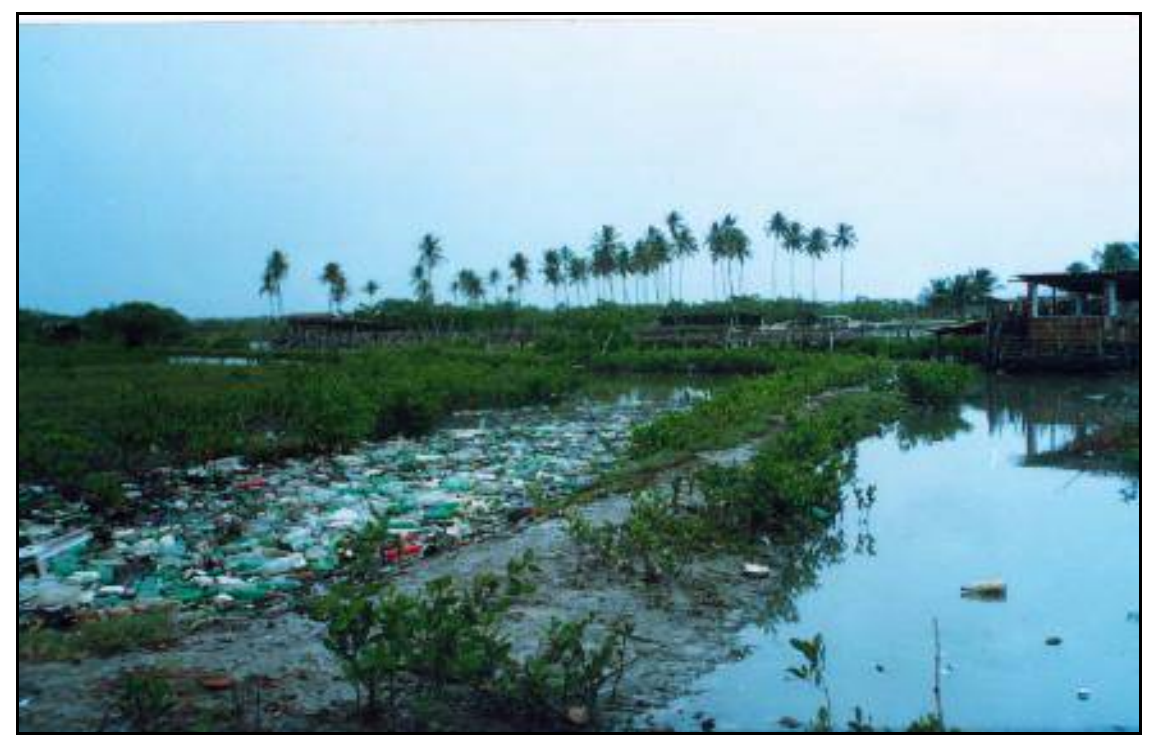

Figura 16 - Lixão formado nas proximidades do Canto do Mangue, fev., 2004

Atualmente, a maior parte da população das comunidades pesqueiras, sobretudo, os moradores a Rua do Porto, foi beneficiada com a construção de casas de alvenaria por parte do poder público municipal, deixando a comunidade com outra configuração (Figura 17).

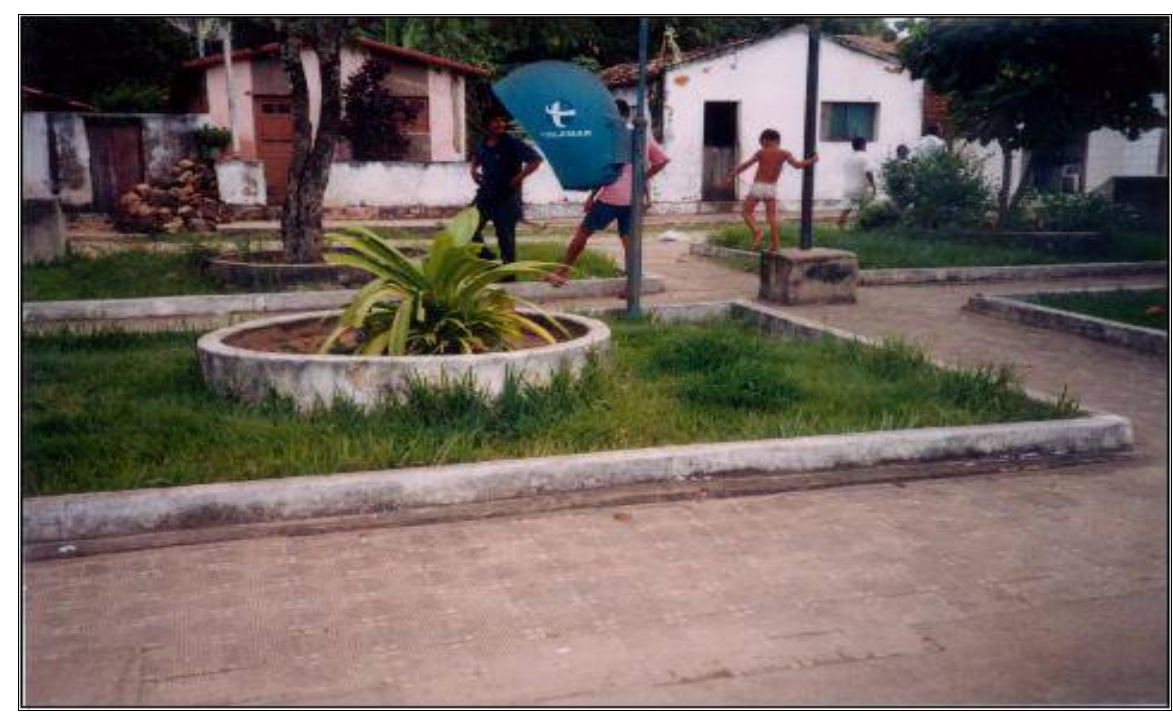

Figura 17 - Canto do Mangue, vista da Rua do Quadro, fev., 2003. 
"Mandaram construir casas novas aqui, na Rua do Porto mesmo fizeram foi um conjunto de casas para os moradores. Mas eu não recebi a minha casa ainda. Assim, vou ficando aqui mesmo no meu cantinho".

Severina, moradora local.

A iniciativa de transferir a população das áreas de risco para outras afastadas da maré já atendeu a diversas famílias, mas ainda é possível encontrar aquelas cuja espera por "novas casas" continua, como mostra a Figura 18.

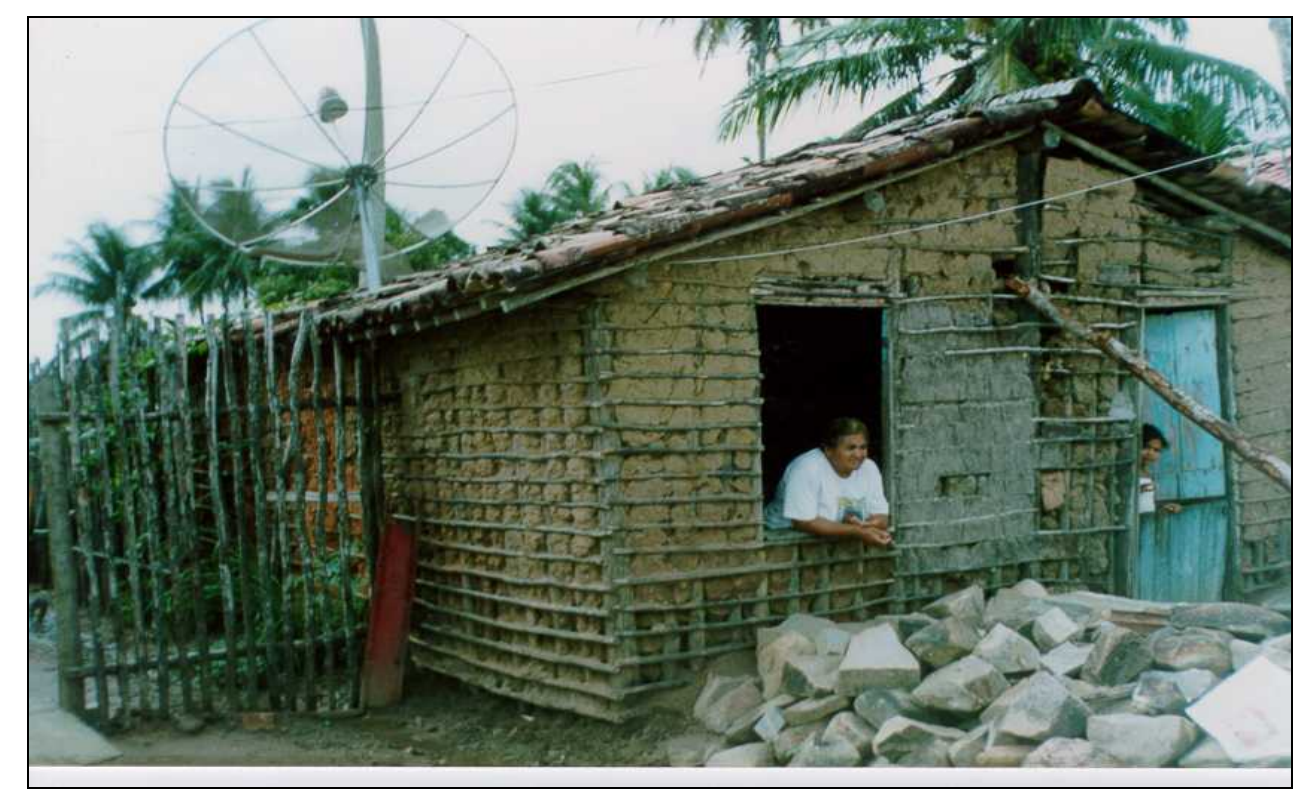

Figura 18 - Moradora do Canto do Mangue aguardando a construção da sua casa, jan., 2003

Em relação à infra-estrutura urbana, as ruas passaram a dispor de pavimentação e serviços básicos, coleta de lixo, abastecimento de água e energia elétrica os quais, no passado, eram considerados privilégios dos mais favorecidos economicamente. 
A inserção dos pescadores na carcinicultura, o benefício concedido no período de defeso e o seguro desemprego levaram ao aumento do poder aquisitivo. Devido a isso pode ocorrer a introdução de pequenos "confortos domésticos" na vida dessas famílias.

Outrossim, nas vantagens da aquisição de eletrodomésticos tais como geladeira, liquidificador e televisão, que passaram a fazer parte do cotidiano da comunidade, se encontram possibilidades de inovações na atividade pesqueira. No caso da conservação do pescado, por exemplo, é possível observar que os pescadores mais organizados financeiramente dispõem de freezer e/ou geladeiras em suas residências, utilizado-os para a produção do gelo levado para conservar o peixe nas pescarias mais longas. No passado, essa conservação era realizada na volta das pescarias. Assim, o peixe era salgado e exposto ao sol para ser consumido ou vendido.

\section{Atividades que complementam a pesca artesanal}

Os moradores, também vêm realizando outras atividades econômicas em complementação à atividade pesqueira, como feirante, ambulante, auxiliar de pedreiro, além da busca por cargos de vigilante, gari e outros que exigem níveis menores de escolaridade.

Entre as queixas apresentadas pelos pescadores que estão deixando a pesca está a dificuldade de ingressar no quadro funcional das empresas de camarão. Os motivos estão associados às exigências relacionadas à escolaridade. Para a ocupação dos postos de baixo escalão exige-se, segundo os moradores, que o trabalhador possua pelo menos as séries iniciais do ensino fundamental. Essa exigência, apesar de pequena em termos de escolaridade, torna-se um fator limitante ao ingresso na atividade, visto que o nível de escolaridade entre os pescadores da comunidade é baixo.

O setor informal da economia é o que absorve a maioria dos pescadores que não conseguem a inserção na carcinicultura. Segundo os relatos, diversos pescadores associados à Colônia, quando recebem o seguro desemprego no período de defeso investem este capital na venda de frutas, verduras, roupas e outras mercadorias, nas feiras-livres do município ou em cidades circunvizinhas. 
Essas atividades formais ou informais realizadas pela população, associadas aos benefícios trabalhistas, além da contribuição feminina (lavadeiras de roupa e domésticas), são alternativas encontradas para substituir, ou complementar a atividade pesqueira.

Analisadas sob uma outra ótica, essas mudanças ocasionadas na vida dos moradores pelo incremento da renda não significaram propriamente melhores condições de vida para a maioria da população, essa passa longe do acesso a uma dieta alimentar equilibrada, assistência médica, educação e lazer.

A preocupação com o desenvolvimento humano deveria ser no sentido de reconhecer que o objetivo real desse desenvolvimento é aumentar as opções das pessoas. Renda é somente uma das opções (extremante importante, diga-se de passagem), contudo, não é o somatório total da vida humana. Saúde, educação, ambiente e liberdade podem ser tão importantes quanto a renda e o se observou na comunidade foi que a "alta do poder" está distante de permitir esses direitos ao moradores.

\section{Perfil dos moradores}

Em relação ao nível de escolaridade dos moradores entrevistados, a Figura 19 mostra que $35 \%$ são analfabetos e $26 \%$ são alfabetizados, ou seja, os chamados analfabetos informais (com menos de quatro anos de escolaridade). O nível de escolaridade se constitui numa preocupação nacional. Dados do Instituto Brasileiro de Geografia e Estatística - IBGE $^{17}$ apresentam a média de analfabetismo de 12,4 no Brasil; na Região Nordeste essa média aumenta para 24,3, praticamente o dobro da nacional.

\footnotetext{
${ }^{17}$ IBGE, Censo Demográfico 2000. Microdados. Rio de Janeiro: IBGE, 2002. 1 CD-ROM
} 


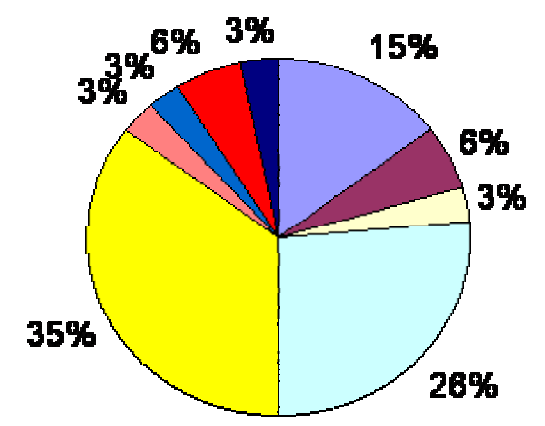

\begin{tabular}{|l|}
$\square$ Ensino Fundamental (incompleto) \\
$\square$ Ensino Fundamental \\
$\square$ Superior (incompleto) \\
$\square$ Alfabetizado \\
$\square$ Não Alfabetizado \\
$\square$ Ensino Médio (incompleto) \\
$\square$ Não Declarou \\
$\square$ Ensino Médio \\
$\square$ Superior
\end{tabular}

Figura 19 - Nível de escolaridade $(\mathrm{n}=34)$

Fonte pesquisa de campo, 2003.

A Figura 20 apresenta a profissão dos participantes e mostra que 37\% são pescadores e $18 \%$ são marisqueiras. Essa constatação abre espaço para uma análise social, cujas evidências, com base nas entrevistas, apontam para o fato de o acesso à escola muitas vezes não contemplar determinados segmentos da sociedade, sobretudo as populações de baixa renda, como pescadores, agricultores, entre outros, que são privados dos direitos básicos do cidadão. 


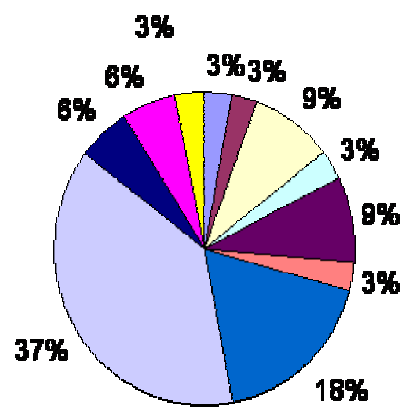

\begin{tabular}{|ll|}
\hline$\square$ Comerciante & $\square$ Costureira \\
$\square$ Dona de Casa & $\square$ Estudante \\
$\square$ Funcionário de Empresa de Camarão & $\square$ Lavadeira \\
$\square$ Marisqueira & $\square$ Pescador \\
$\square$ Pescador Aposentado & $\square$ Presidente de Colônia de Pescadores \\
$\square$ Professora & \\
\hline
\end{tabular}

Figura 20 - Profissão dos entrevistados $(n=34)$

Fonte: pesquisa de campo, 2003.

No Canto do Mangue, como se pode constatar na Figura 19, existe uma parcela elevada de pessoas não alfabetizadas, sobretudo, aquelas que se encontram numa faixa etária mais elevada, como é possível observar na Figura 21. Esse fator pode estar relacionado ao envolvimento das crianças com a pesca, principalmente há décadas atrás, quando era comum as crianças deixarem de freqüentar, ou até mesmo nem chegarem a freqüentar a escola, por ajudarem os pais nas pescarias. 


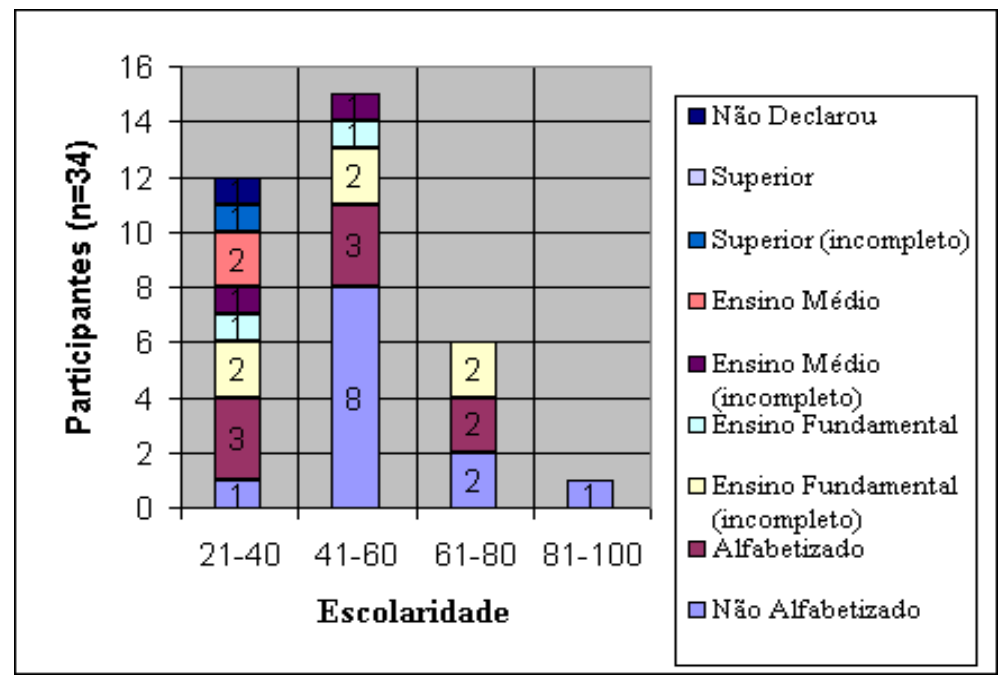

Figura 21 - Nível de escolaridade por classes de idade $(n=34)$

Fonte: pesquisa de campo, 2003.

"Comecei a pescar ainda menino, o meu pai era pescador $e$ me levava nas pescarias, juntamente com os meus dois irmãos. Naquele tempo não se tinha direito de ir à escola como hoje que essa meninada toda já pode ir”.

Quinca, pescador.

A mesma constatação também foi observada por Almeida \& Teixeira (1993) e Woortmann (1992) em outras comunidades pesqueiras do Rio Grande do Norte. É possível observar um maior número de pessoas analfabetas, 41\%, na faixa etária entre 41 a 60 anos de idade, enquanto os componentes do intervalo de 21 a 40 anos, 32\%, apresentam uma parcela menor de analfabetos, sendo ainda possível verificar que os componentes dessa faixa etária se encontram bem distribuídos nos demais níveis de escolaridade, exceto o superior.

O nível de escolaridade e a idade têm peso decisório na vida daqueles que buscam empregos na carcinicultura. Atualmente, a baixa escolaridade associada à idade elevada torna-se empecilhos ao ingresso e permanência no mercado de trabalho, como 
foi mencionado no item anterior pelos moradores do Canto do Mangue. Mas a ampliação do número de escolas no município, nas duas últimas décadas, os programas de incentivo das políticas educacionais vigentes, como o programa "Bolsa Escola" (proporciona uma contribuição financeira às famílias que mantêm seus filhos menores de 15 anos na escola), além do desejo dos moradores que seus filhos tenham acesso à educação formal, são indicadores a ser considerados, apontando para a elevação do nível de escolaridade na comunidade.

Foi possível observar durantes visitas realizadas em Canguaretama uma maior preocupação do Poder Municipal em relação à ampliação dos números de vagas nas escolas e na formação de professores.

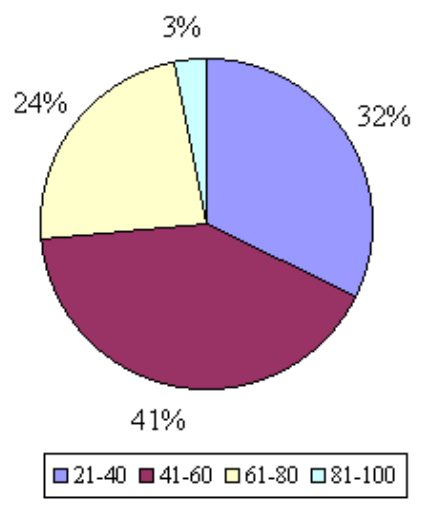

Figura 22 - Faixa etária $(n=34)$

Fonte: pesquisa de campo, 2003.

$\mathrm{Na}$ Figura 22 se verifica que uma parcela expressiva dos entrevistados encontra-se entre 41 e 60 anos de idade: 41\%. Isso favoreceu a compreensão da atividade pesqueira na comunidade, devido à experiência dos entrevistados na pesca, como também contribuiu para o entendimento das mudanças ocorridas no espaço local nas últimas décadas, especialmente após a introdução da carcinicultura.

A maioria das entrevistas foi realizada com indivíduos do sexo masculino, como apresenta abaixo a Figura 23, devido à prioridade inicial da pesquisa ter sido ouvir 
o maior número de pescadores possível. Porém, no decorrer do trabalho, observei que a Colônia de Pescadores de Canguaretama agregava muitas mulheres associadas, as chamadas marisqueiras.

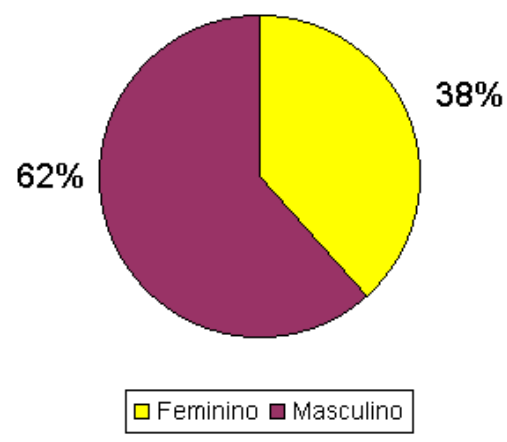

Figura 23 - Distribuição dos entrevistados por sexo $(n=34)$

Fonte: pesquisa de campo, 2003.

Com isso, ocorreu a oportunidade de ouvir os relatos do universo feminino e suas contribuições diretas e indiretas nas pescarias, de forma a enriquecer ainda mais a compreensão de elementos simbólicos e práticos que servem para diferenciar as atividades de gênero nas comunidades pesqueiras.

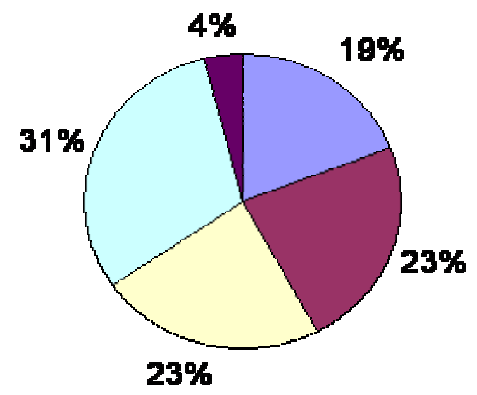

$\square 1$ a $2 \square 3$ a $4 \square 5$ a $6 \square 7$ a $8 \square 9$ a 10

Figura 24 - Número de filhos por famílias $(n=26)$

Fonte: pesquisa de campo, 2003. 
Quanto ao número de filhos, a Figura 24 mostra que $31 \%$ das famílias entrevistadas no Canto do Mangue têm de sete a oito filhos. A média é 5 (cinco) filhos, com desvio padrão de 2 (dois) filhos por família. Essa média é bastante elevada, tomando como parâmetro a média nacional de fecundidade de $2,4^{18}$, e mesmo a média da Região Nordeste de 2,7 filhos por mulher em idade fértil (15 a 45 anos).

No que se refere ao estado civil dos entrevistados, a Figura 25 apresenta que a maioria, 64\%, é casada. Nas sociedades pesqueiras, os casamentos auxiliam na formação dos grupos de pesca, geralmente constituídos por membros da família. Assim, como a atividade se dá no âmbito familiar, a importância de se constituir família é bastante reconhecida entre os membros dessas sociedades.

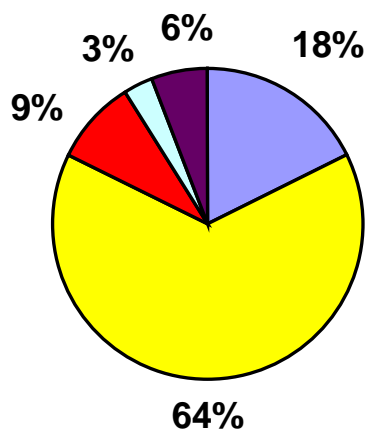

口Solteiro $\square$ Casado $\square$ Viúvo $\square$ Separado $\square$ Não declado

Figura 25 - Estado civil dos comunitários $(n=34)$

Fonte: pesquisa de campo, 2003.

Em suma, constatou-se que parte da população do Canto do Mangue nas últimas duas décadas passou a dispor de melhorias na infra-estrutura urbana e nas condições de moradia, assim como de maior acesso a direitos básicos como a educação, ao menos para as novas gerações. Entretanto, essa população ainda enfrenta graves problemas de ordem sanitária, como a ausência de saneamento básico e os lixões que se

\footnotetext{
${ }^{18}$ IBGE, Censo Demográfico 2000. Microdados. Rio de Janeiro: IBGE, 2002. 1 CD-ROM.
} 
formam no entorno da comunidade. Estando localizada nas margens da maré, ela recebe os esgotos domésticos a céu-aberto, além dos escoamentos pluviais da cidade. Assim, o Canto do Mangue se constitui numa área de risco para a saúde dos moradores, sobretudo das crianças que costumam freqüentar as imediações da maré, na intenção de brincarem e tomarem banhos.

\section{Hábitos alimentares}

A alimentação básica no Canto do Mangue consiste de pescados (peixe, crustáceos e mariscos), frutas da região e gêneros alimentícios como o arroz, o feijão, o macarrão e a farinha de mandioca, comprados nos supermercados da cidade, na feiralivre ou mesmo em pequenas mercearias. As carnes bovina, suína e de aves são consumidas com menor freqüência, sendo consideradas alimentação para dias especiais.

Esses hábitos são semelhantes aos de outras comunidades litorâneas do Rio Grande do Norte, como verificou Silva (1999) em Baía Formosa, outro entre os municípios pesqueiros do Estado. Os pescadores têm como elemento chave da dieta alimentar o peixe, acompanhado da farinha de mandioca, macaxeira, batata, feijão e outros gêneros.

“A alimentação do pescador é mais o peixe. Eu como peixe todo, me criei desde menino com o peixe. Eu fui a uma viagem e no Ceará passei fome, você pode acreditar que passei fome, porque não gosto de comer outras coisas que não seja o peixe, coisas da maré, do mar. Agora, a mulher não gosta muito, ela diz que já está abusada”.

Quinca, pescador.

O peixe e os demais recursos comestíveis aquáticos são as bases da dieta dessas populações, como observaram Hanazaki (2002) nas populações caiçaras do litoral 
paulista; Diegues \& Nogara (1999) no Saco de Mamanguá, no Rio de Janeiro, e Morán (1990) em populações ribeirinhas da Amazônia.

Os autores desses trabalhos apontam que os hábitos alimentares das comunidades pesqueiras constituem-se num dos mecanismos de construção e expressão da identidade do grupo. De acordo com Maldonado (1986, p. 65), "peixe é o principal alimento entre essas populações, sendo bastante apreciado e considerado saudável com qualidade protéica superior aos demais alimentos".

Existem exceções ao apreço do peixe nas comunidades pesqueiras. No Canto do Mangue foi possível verificar que, mesmo o peixe sendo considerado por muitos habitantes como um alimento saudável, encontrei moradores que se queixam de estarem “enjoados" de consumir pescado todos os dias.

"Eu gosto de frango, não tenho gosto de comer peixe de maré, agora o peixe quando é grande ou é de mar eu ainda como, são poucos os peixes que eu como".

Tonha, marisqueira.

O peixe é a base da dieta alimentar desses moradores, mas se constatou que existem alguns que possuem nos quintais domésticos, ou nas imediações do rio, porcos e galinhas que servem de reserva financeira, podendo ser vendidos ou consumidos nos fracos períodos de pescaria.

Vannucci (1999) destaca que, embora o homem tenha se adaptado à vida nas proximidades dos manguezais, teve de se defrontar com alguns problemas sérios. Um deles é a dieta, pois ainda que disponha do alimento de origem animal, rico em proteínas e de forma abundante, nas diversas espécies de peixes, crustáceos e moluscos existem carência de outros nutrientes, o que pode ocasionar problemas à saúde da população.

Assim, o homem do manguezal é bem nutrido com proteínas, mas com propensão a deficiências crônicas de algumas vitaminas e minerais, com tendência a desenvolver problemas renais e doenças de pele devido às micoses e viroses favorecidas pela constantemente elevada umidade do ar, que também ocasiona doenças respiratórias. 
Para Castro (2001), o modo de vida (as condições de moradia e os hábitos alimentares) das populações que têm nos manguezais a sua fonte de subsistência é semelhante em diversos países dos continentes (africano, asiático e latino-americano). Entretanto, esse autor ressalta que a exclusão social, o baixo nível de escolaridade, o baixo acesso aos serviços de saúde e a outros direitos básicos dos cidadãos também são agentes estressores comuns às populações humanas que habitam a faixa intertropical e se deparam com a apropriação empresarial dos manguezais, atualmente explorados de forma indiscriminada; isso foi também constatado no Canto do Mangue.

Em síntese, o que se pode constatar em relação ao modo de vida da população do Canto do Mangue, com base no exposto, é que para uma parcela dos moradores, após a introdução da carcinicultura, houve aumento no poder aquisitivo, que por sua vez, criou nessa população "novas necessidades". Balandier (1997) afirma que nada pode ser mantido por puro imobilismo. Assim, as populações de pescadores possuem uma dinâmica própria, mas a carcinicultura acelera essa dinâmica, na medida em que se apropria e transforma o espaço-temporal dessa população.

Analisada sob os parâmetros do desenvolvimento sustentável, essa constatação leva a algumas reflexões. Mais uma vez, se observa que é um grande desafio considerar o desenvolvimento econômico comprometido em atender às necessidades presentes, sem comprometer as necessidades das futuras gerações.

Para Morin (2000), somente com o reconhecimento da antropo-ética, que supõe a consciência de assumir a condição humana (individuo, espécie, sociedade), e o reconhecimento da interdependência entre os homens e todos os elementos do sistema Terra será possível se alcançar a cidadania planetária e a justiça social.

É, portanto, por meio de alianças e divórcios, concretos ou abstratos, que as intervenções ambientais vão se entretecendo, tudo dentro de uma ampla dinâmica cultural. Desse modo, as mudanças ocorridas no ambiente, sejam de ordem econômica ou ecológica, contribuem fortemente para a perda da identidade cultural e dos saberes da tradição, sendo necessário traçar metas de planejamento econômico-ambiental que consistam em propor direções para a dinâmica sócio-cultural dos moradores (Marques, 1999). 


\subsection{As relações sociais no Canto do Mangue}

\section{Divisão do trabalho}

No Canto do Mangue o trabalho na atividade pesqueira envolve a unidade familiar e as tarefas são realizadas de acordo com o sexo. Os homens realizam a pesca e os filhos passam a acompanhar e a ajudar o pai desde cedo. Já as mulheres e as filhas se encarregam das atividades domésticas, dos consertos e confecção das redes, da coleta dos moluscos, do tratamento e comercialização do pescado. A importância do trabalho da mulher e dos filhos é reconhecida pelos pescadores, e a ajuda familiar se torna primordial para o sucesso na captura e comercialização do pescado. Assim, é comum nas comunidades de pescadores artesanais o elevado número de filhos, haja vista a atividade se dar no âmbito familiar, no qual crianças e adolescentes ajudam os pais nas tarefas diárias (Figura 26).

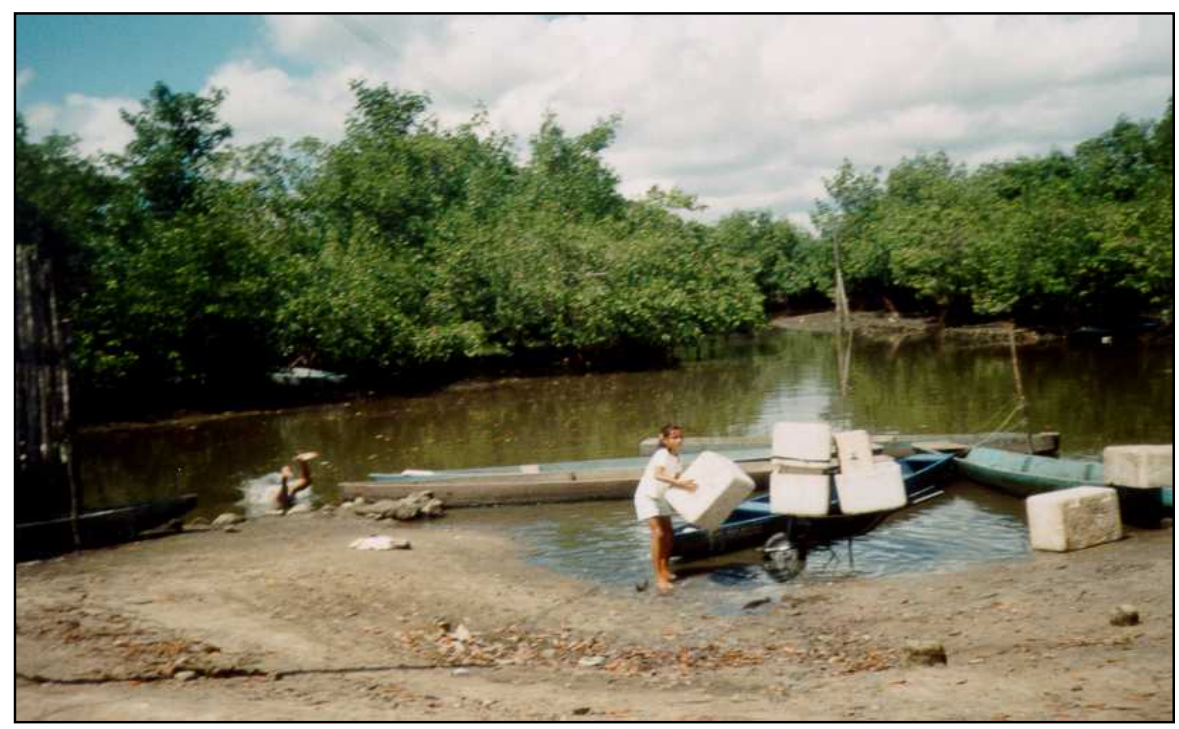

Figura 25 - Criança ajudando na limpeza dos apetrechos de pescaria, fev,. 2003

“A gente faz assim, eu pesco e ela [a esposa] é quem leva o pescado para vender na feira ou no mercado. É uma forma da gente ganhar um pouco mais, pois quando se vende ao 
atravessador, o ganho fica menor, isso porque sempre vendemos por um valor bem menor do que o valor de mercado. Agora eu mesmo não gosto de ir vender. Isso fica por conta da mulher”.

José Geraldo, pescador.

"Quando se vende o marisco, o sururu, a outra aí se faz assim, o dinheiro é para comprar as nossas coisas, os enfeites: broches, um batom, uma caixa de pó, comprar roupinhas para os meninos pequenos, um perfume, um sabonete, essas coisinhas de mulher. Mulher gosta de andar enfeitada, não é? A gente também trabalha em tarrafas, o pescador encomenda e a gente faz. Eles pagavam para fazer e o preço é por braça da tarrafa, agora se a malha for grande o preço é mais barato, porque dá menos trabalho, mas se a malha for fina, miúda, o preço era mais alto, porque levava mais tempo pra se fazer, não é?”.

Adelma, marisqueira.

A divisão do trabalho ocorre por sexo na maioria das comunidades pesqueiras, salvo algumas exceções, como constatou Walter (2000) junto a pescadores do Lago Paranoá, em Brasília, Distrito Federal. No Rio Grande do Norte, Moura \& Teixeira (1993) também constataram esse fato na lagoa do Piató, em Assu, e Woortmann (1992) nos municípios litorâneos de Rio do Fogo e Baía Formosa. É hábito o pescador mencionar a existência de determinadas tarefas de pesca que apenas os homens podem realizar, assim como existem locais de pescarias "proibidos” para mulheres.

Eles alegam que os perigos enfrentados até a chegada a esses pontos (ventos, correntes marítimas, profundidade) se constituem empecilhos à presença feminina, além dos mitos referentes à presença feminina nos seus territórios de trabalho. Para Woortmann (1992), a classificação do espaço natural é também uma classificação de espaços sociais e de domínios pertinentes ao gênero. Dessa maneira, as mulheres se encarregam da pesca de mangue, ou seja, da coleta de moluscos, em áreas que não 
oferecem grandes perigos. E os homens encarregam-se de áreas mais distantes - nos estuários ou no mar.

A pesquisadora Marta Vannucci afirma em Os Manguezais e Nós (1999) que são muitas e variadas as lendas criadas pelo homem em relação ao ambiente por ele habitado, sendo transmitidas de geração em geração pela tradição oral. As lendas e os mitos possuem uma razão prática na orientação da vida coletiva, pois constituem poderosos instrumentos educacionais para os habitantes de um determinado ecossistema e, conseqüentemente, através desses ensinamentos, pode-se promover a divisão de atividade para a aquisição de recursos entre os componentes do grupo, favorecendo o uso sustentável dos recursos naturais.

\section{Relações de parentesco}

As relações de parentesco na comunidade podem ser consideradas um fator fundamental para o estabelecimento e manutenção da rede social que une os seus moradores num conjunto mais amplo.

Eles fixam residência e constroem família entre si. É normal se encontrar casais de duas ou três gerações (avós, pais e netos) habitando juntos a mesma residência. $\mathrm{O}$ mais comum é o homem, ao casar, passar a morar na casa dos pais da sua esposa, o que os estudos antropológicos qualificam como "matrilocalidade". Entretanto, essa constatação não se constitui uma regra, podendo ser encontradas situações inversas entre alguns casais, permanecendo essa prática até que os casais disponham das suas próprias residências. Já em 1957, Cascudo (p. 49) verificou que "nas comunidades é comum casar-se cedo". Isso também foi constatado nos dias atuais, no Canto do Mangue, durante as visitas realizadas na comunidade ao longo do trabalho.

"Para pescar se leva os filhos, um sobrinho, um cunhado, os parentes. Quando falta um que faz parte do grupo, aí se chama um colega vizinho, também pescador. Pesca-se e depois se reparte o dinheiro com a quantidade de pescador que tenha ido à pescaria. 
Agora o bom é a gente levar o pessoal de casa, um filho, um irmão porque aí o dinheiro fica mesmo é em casa, mas se falta um, a gente leva uma colega. Quando se volta da maré o peixe é vendido ao "pombeiro"19. Agora quando não se vende, ou o peixe é de qualidade ruim para venda, a gente reparte igualmente o pescado e distribui com todos os que participaram da pescaria. Antes mesmo de vender o peixe, cada um tira o seu almoço e se tiver alguém necessitando a gente dá o almoço daquele pescador que tiver precisando".

Quinca, pescador.

A estreita relação entre os componentes da comunidade fortalece os laços de solidariedade e cria normas de conduta entre os pescadores, fazendo-os sentirem-se responsáveis pela alimentação dos componentes do grupo. Aqueles que realizam melhores pescarias já retiram da produção a parte destinada ao consumo familiar e também aquela distribuída aos membros da comunidade que estejam necessitando de ajuda. Essa ajuda se dá aos pescadores mais velhos do grupo, sendo ou não familiares, podendo ser prestada também àqueles que pescam, mas que por motivos de saúde não têm trabalhado e até mesmo àqueles que estão pescando, mas que não realizaram boas pescarias.

Os moradores mantêm estreitas relações de amizade, uma vez que a maioria, $85 \%$, é nascida na comunidade ou em seu entorno, como apresenta a Figura 27. Os advindos de outros municípios do Rio Grande do Norte ou dos Estados vizinhos, em geral, já são moradores da comunidade há muitos anos.

\footnotetext{
${ }^{19}$ Denominação local atribuída aos atravessadores.
} 


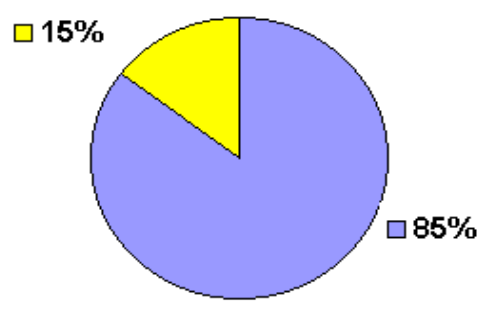

$\square$ Canguaretama $\square$ Outros

Figura 27 - Naturalidade dos comunitários ( $\mathrm{n}=34)$

Fonte: pesquisa de campo, 2003.

Estudo realizado por Maldonado (1986) na comunidade de Ponta de Mata, município de Cabedelo, litoral paraibano, verificou que a solidariedade e a relação de pertencer ao lugar é um traço significativo como expressão do modo de ser e viver do pescador. Tais laços podem ser atribuídos à relação de parentesco entre os grupos. Entre os pescadores, quando um não pode mais realizar suas atividades, seja por motivos de velhice, doenças, morte de um ente querido, perda do material de pescaria, ou qualquer outro motivo que possa fazê-lo se desinteressar da pesca, é comum a ajuda dos demais membros do grupo que estão realizando as suas pescarias com "sucesso".

"São todos unidos e se alguém precisar um ajuda ao outro, dão o almoço de peixe, emprestam dinheiro enquanto os outros vão trabalhar. Daí quando aquele colega chega da maré com o peixe e vende, o dinheiro é para pagar o amigo. É uma vizinhança muito unida nesse ponto. Para os mais humildes, que possui redes fracas, tem aqueles que dizem: 'rapaz você hoje não pegou foi nada. Eu vou the dar um almoço de peixe'. Aí vai e dá aquela bacia de peixe sem ser dos grandes, pois os graúdos são para vender. Seu Duda [um pescador conhecido na comunidade] mesmo estava cansado de 
fazer isso. Eles são unidos e gostam de fazer favor, e não deixam os outros passarem fome”.

Adelma, marisqueira.

Assim, são freqüentes as instâncias de doação e trocas de peixe. Quando um pescador está passando por um momento econômico difícil conta com a ajuda dos companheiros de pescaria, sendo que esses passam a assistir a família do colega por meio do fornecimento de alimentos.

\section{A Colônia de Pescadores}

Os pescadores de todas as categorias de todo o país são reconhecidos como classe trabalhadora profissional somente se estiverem vinculados às Colônias de Pesca, que representam essa categoria da população do país.

A Colônia de Pescadores $Z$ - 06, município de Canguaretama, foi fundada em 1916 e é a pioneira no Estado do Rio Grande do Norte. Como muitas outras, está sentindo os reflexos das mudanças introduzidas a partir de uma nova legislação pesqueira, bem como das novas atividades econômicas que foram introduzidas no município nas duas últimas décadas.

As ações a partir da influência que os indivíduos exercem na Colônia partem inicialmente dos pescadores inclusos no quadro social. Ou seja, como associados eles podem votar para decidir normas internas e usufruírem os benefícios concedidos à categoria. Foi possível verificar que, entre os principais fatores que influenciam o ingresso do pescador à Colônia, encontra-se a herança da "profissão" dos antepassados. Os avós, bem como os pais, eram pescadores e desde cedo ensinavam o ofício aos filhos, que ainda crianças já os acompanhavam na pesca.

Outrossim, dentro do município, onde o número de pescadores não associados à Colônia é desconhecido, benefícios conquistados pela categoria contemplam apenas uma pequena parcela de pescadores. A maioria daqueles que foram ouvidos se referiu aos não associados como sendo "pescadores clandestinos". 
Os chamados "clandestinos", por sua vez, tecem comentário em relação à legitimação e profissionalização de muitos pescadores que são sócios da Colônia, alegando que grande parte daqueles têm por finalidade serem beneficiados pela Lei $\mathrm{n}^{\circ}$ 8.287, de 20 de dezembro de 1991, que confere o direito do seguro desemprego durante o período de defeso da lagosta aos profissionais devidamente registrados. Para os nãosócios, algumas pessoas terminam se beneficiando das vantagens adquiridas por lei pelo pescador.

Outro ponto importante, destacado por sócios da Colônia, diz respeito ao recebimento do seguro desemprego, pois antes desse benefício as mulheres que coletavam moluscos não se reconheciam como profissionais da pesca. Com esse direito adquirido, passaram a assumir a atividade como profissão, orgulhando-se de poder ajudar os seus esposos no orçamento doméstico.

A Colônia, como entidade representativa dos pescadores, apresenta uma forma peculiar de organização, pois em termos de benefícios para os cadastrados a entidade é o “primeiro lugar" onde o pescador tem apoio para começar a exercer sua profissão.

No tocante às relações de trabalho, foi possível encontrar em Canguaretama pescadores que são proprietários das embarcações nas quais trabalham e dos materiais que utilizam na pesca, e aqueles que pescam em barcos ou canoa de outros, com redes e instrumentos de terceiros.

Os conflitos entre os interesses de grupos ou indivíduos são revelados em discursos que exprimem anseios, isso em conversas informais nas dependências da Colônia, ou na comunidade. É comum se ouvir aspirações, inquietações e intrigas com relação à entidade e aos seus componentes. Aqueles pescadores que trabalham em barcos de terceiros têm como reivindicação primordial o financiamento para a aquisição de suas próprias embarcações. Enquanto que a mesma reivindicação tem peso diferenciado para os que já são proprietários de embarcação e vislumbram novos investimentos em outros setores, como a comercialização.

Com os mesmos poderes dos sindicatos de trabalhadores rurais, a Colônia de Pescadores Z-06 de Canguaretama, com o amparo da atual legislação pesqueira, elaborou um projeto pleiteando a compra de uma máquina de gelo. Esse foi submetido 
ao Projeto de Amparo ao Pequeno Produtor - PAPP, ocorrendo a sua aprovação, aproximadamente, em 1997.

A iniciativa visava fortalecer o poder da Colônia e tinha como objetivo fornecer o gelo utilizado pelos pescadores que ficam a semana inteira nos seus pontos de pesca. De acordo com o projeto, também seria criada uma cooperativa para beneficiar o pescado e fornecê-lo ao mercado local. Dessa feita, a cooperativa estabeleceria uma parceria com a Prefeitura Municipal de Canguaretama, que se responsabilizaria por comprar parte da produção beneficiada para ser utilizada na merenda das escolas do município.

Para melhor compreensão dessa iniciativa, verifiquei os objetivos do Projeto de Amparo ao Pequeno Produtor - PAPP e sua atuação no contexto da comunidade pesquisada. O PAPP é uma iniciativa do governo do Estado, financiada em parte pelo Banco Mundial, e tem como meta principal contribuir para a redução da pobreza no meio rural e para o fortalecimento do processo de organização e participação das comunidades, bem como o aperfeiçoamento do processo de tomada de decisão ao nível municipal (PAPP, 1997).

O projeto financia subprojetos produtivos, de infra-estrutura econômica e social de interesse das comunidades. Para tanto, os subprojetos devem visar ao aumento da renda local e a ocupação dos beneficiários.

A partir das informações obtidas e das observações in loco, verifiquei que o projeto de aquisição da máquina de gelo, mesmo sendo uma iniciativa que contemplaria a comunidade de forma expressiva, não chegou a ser totalmente desenvolvido. A compra da máquina foi realizada, mas por falta de verba para a sua instalação, ela não chegou a funcionar.

Segundo o presidente da Colônia que estava na gestão em janeiro de 2003, Luiz Marques da Cruz, a máquina estava parada há três anos, encontrando-se em estado de depreciação. Ele alegou que a formação da cooperativa inicialmente contava com o apoio dos pescadores, mas aos poucos o espírito de coletividade foi questionado por aqueles pescadores que tinham uma produção mais expressiva e sentiam-se prejudicados com a idéia de serem nivelados aos pescadores que apresentavam uma produção menor, 
mesmo que os lucros fossem distribuídos de acordo com a produção. Para os pescadores proprietários dos seus instrumentos de trabalho, existem diferenciações entre eles e aqueles que não são donos dos seus barcos e dos apetrechos de pescaria.

O projeto não se concretizou e o não pagamento dos recursos financeiros que foram destinados à compra da máquina deixou a Colônia de Pescadores sem crédito para lançar-se em novos empreendimentos, ou seja, novas linhas de crédito que pudessem estar sendo oferecidas por instituições estaduais, regionais e(ou) federais. A inadimplência da entidade é atribuída, por parte dos pescadores, à falta de apoio político e às divergências com os grupos de pescadores que não concordaram com a criação da cooperativa. Todavia, os argumentos parecem mascarar uma realidade mais ampla.

A renúncia ao poder na Colônia Z-06 chamou a atenção. O presidente Luis Marques da Cruz estava no cargo desde 1994, tendo sua escolha ocorrida de forma indireta. Já durante o segundo semestre de 2003, na segunda etapa do trabalho de campo, Luiz havia sido substituído por um presidente indicado pela Federação de Pesca do Rio Grande do Norte. Os motivos do seu afastamento não foram esclarecidos e o contato que consegui realizar com o novo presidente da Colônia foi breve.

Em relação ao envolvimento dos pescadores do Canto do Mangue com a Colônia, observei que um grande número de pescadores deixa de participar da vida política de sua entidade de representação. Quando questionados sobre a substituição do presidente, poucos faziam comentários a respeito.

Os pescadores parecem se contentar com o acesso aos benefícios previdenciários assegurados por lei. Nessa busca pelo entendimento político e organização da categoria, foi possível verificar que os pescadores não associados ficam sem acesso aos direitos previdenciários. Campanhas de esclarecimento sobre os direitos dos pescadores e importância da sua participação na Colônia poderiam ser realizadas por órgãos competentes como o IBAMA, a Federação de Pesca do Estado e a própria Colônia do Município.

Em janeiro de 2003, Sr. Luiz reclamou da falta de participação dos pescadores e também dos atrasos nos pagamentos da contribuição mensal. Para ele, os atrasos refletiam nos custos com a manutenção de serviços básicos, como a água e a energia 
elétrica. Ainda segundo ele, o caso se agravou muito nos últimos anos, chegando ao ponto optar por fazer uso da água ou da energia elétrica, uma vez que as dívidas com esses serviços ultrapassavam a disponibilidade de verbas que a Colônia dispunha para os pagamentos no período.

Contudo, os pescadores também reclamavam que a Colônia pouco beneficiava os associados, fazendo ressalvas às conquistas do seguro desemprego e algumas vezes à aposentadoria por tempo de serviço. São esses dois direitos trabalhistas que apareceram nas falas dos associados como responsáveis pela melhoria na qualidade de vida dos pescadores do município.

Estudo realizado por Quaresma (1987), sobre a pesca artesanal em Canguaretama, menciona que a meta da Colônia de Pescadores Z-06 naquele período era proporcionar ao quadro social condições favoráveis para o desenvolvimento do bemestar de cada sócio, fazendo chegar para cada um e aos seus dependentes pelo menos uma parcela de assistência médica, educacional e outros serviços básicos.

Metas que não foram alcançadas e o quadro dos pescadores permanece nas mesmas condições do passado, em relação a esses serviços. No entanto, as promessas de cumprimento das melhorias continuam nos discursos dos representantes da entidade.

$\mathrm{O}$ assistencialismo que caracteriza as Colônias faz com que elas funcionem mais como postos de saúde, grupos escolares e locais de reuniões e festas dos moradores do que propriamente como associação de classe, onde os direitos dos pescadores deveriam ser discutidos e zelados (Maldonado, 1986).

As preocupações dos associados em relação às alterações que estão ocorrendo na pesca artesanal são relativas à degradação dos manguezais, à redução do estoque pesqueiro e aos bloqueios das rotas de pesca pelas empresas de camarão. Porém, não constatei nem uma iniciativa da Colônia no sentido de estabelecer diálogo entre pescadores e empresários, visando à busca de soluções que viabilizem a resolução desses problemas.

Para Maldonado (ibid.) e Diegues (1995), faz parte das generalizações sobre os pescadores dizer-se que eles não são politizados e que têm pouca capacidade de organização para reivindicarem os seus direitos. Mas é preciso considerar que muitas 
vezes os interesses coletivos são postos em segundo plano e as organizações são utilizadas com fim de controle social e político, seguindo os interesses da minoria.

Em Canguaretama, esses interesses também coexistem por parte de pequenos grupos que estão diretamente em contato com o poder público. Devido a trocas de favores e interesses pessoais, a categoria fica sem representatividade na tomada de decisão para a solução de problemas comuns à classe, como a participação em propostas de gerenciamento do uso, manejo e conservação dos recursos das áreas costeiras.

\subsection{Conflitos e benefícios decorrentes da carcinicultura}

Um ponto conflituoso referente à implantação das empresas de camarão em cativeiro diz respeito aos benefícios da atividade na economia do município e, de forma mais restrita, na vida dos moradores do Canto do Mangue, que habitam um espaço circundado por viveiros.

Para os pescadores e moradores do Canto do Mangue, as empresas de carcinicultura apresentam uma dualidade. Eles as classificam como "boas" e "ruins", ao mesmo tempo, para quem mora na comunidade. Vistas pelo viés do aumento de empregos e do cumprimento dos direitos trabalhistas dos funcionários, essas empresas são consideradas "boas" por quem reside na comunidade. Quando são analisadas sob a ótica ambiental, ou seja, o acelerando corte dos manguezais, que contribui para a redução do estoque pesqueiro, além do fechamento das rotas pesqueiras e emissão de efluentes para o estuário, fatores atribuídos à carcinicultura por grande parte da população local, elas passam a ser consideradas "ruins".

A premissa de que a implantação dos viveiros está destruindo os manguezais do Estado é levantada por todos os moradores da comunidade, e pode ser constatada na mídia estadual como destaca o Jornal Tribuna do Norte, de Natal (RN):

“CARCINICULTURA ameaça mangues (...) A carcinicultura desordenada está acabando com os manguezais do Rio Grande do Norte. As fazendas de camarão já atingiram mais de 6 mil hectares 
de mangue e o IBAMA alega que não dispõe de ficais suficientes para cobrir todo o Estado potiguar..." (2003).

"VIVEIROS ameaçam área de mangues (...) Ministério público vai entrar nos próximos dias com ação criminal contra criadores de camarão que utilizando práticas ilegais dificultam a recuperação do rio Potengi [em Natal]..." (2001).

"IBAMA aplica 53 autos em carcinicultores (...) A mega-operação de fiscalização que está sendo feita pelo Instituto Brasileiro de Meio Ambiente e Recursos Naturais Renováveis no Rio Grande do Norte aplicou em uma semana 53 autos de infração em proprietários de áreas de cultivo de camarão. As infrações foram desmatamento de mangue e falta de licenciamento do Instituto de Desenvolvimento Econômico e Meio Ambiente do Rio Grade do Norte...” (2001).

Como foi possível verificar, os meios de comunicação, do Estado, apresentam a devastação dos manguezais e a falta de licenciamento como infrações que preocupam os órgãos responsáveis pela fiscalização ambiental (IDEMA e IBAMA). Porém, existe um número insuficiente de fiscais para atuarem em todo o litoral potiguar, onde se concentram as áreas de cultivo.

É importante ressaltar que, com base na coletânea de matérias jornalísticas analisadas, referentes a essa temática, no geral a mídia impressa estadual apresenta com maior expressividade os aspectos "positivos" da atividade. Ou seja, o crescimento desta no mercado, os lucros obtidos, os avanços biotecnológicos e a participação do Estado no ranking dos exportadores nacionais de camarão para blocos econômicos. Entretanto, é preciso também mostrar igualmente uma outra realidade, desagradável: os impactos negativos sobre o ambiente e sobre as populações humanas, que convivem com expansão predatória da carcinicultura. 
Partindo da proposição de que o corte acelerado dos manguezais ocasiona graves problemas de ordem sócio-ambiental, como a ameaça à biodiversidade e a redução dos estoques pesqueiros no Estado, contribuindo assim para o abandono da atividade pesqueira em muitas comunidades litorâneas e, conseqüentemente, levando à perda dos saberes dessas populações, procurei verificar quantitativamente o comportamento da produção de pescado no município.

A Figura 28 apresenta a produção de pescado em Canguaretama, no período de 1993 a 2002, mostrando uma média anual de 164,1 toneladas (ton), com aumento na produção nos anos de 1997 a 1999 (a média desse período foi de 246,5 ton), apresentando um pico em 1999 de 293,9 ton. Porém, há uma expressiva queda na produção nos anos de 2000 e 2001, respectivamente. Nesse intervalo, a média é de 92,9 ton, atingindo seu mínimo de 84,3 ton no ano de 2001.

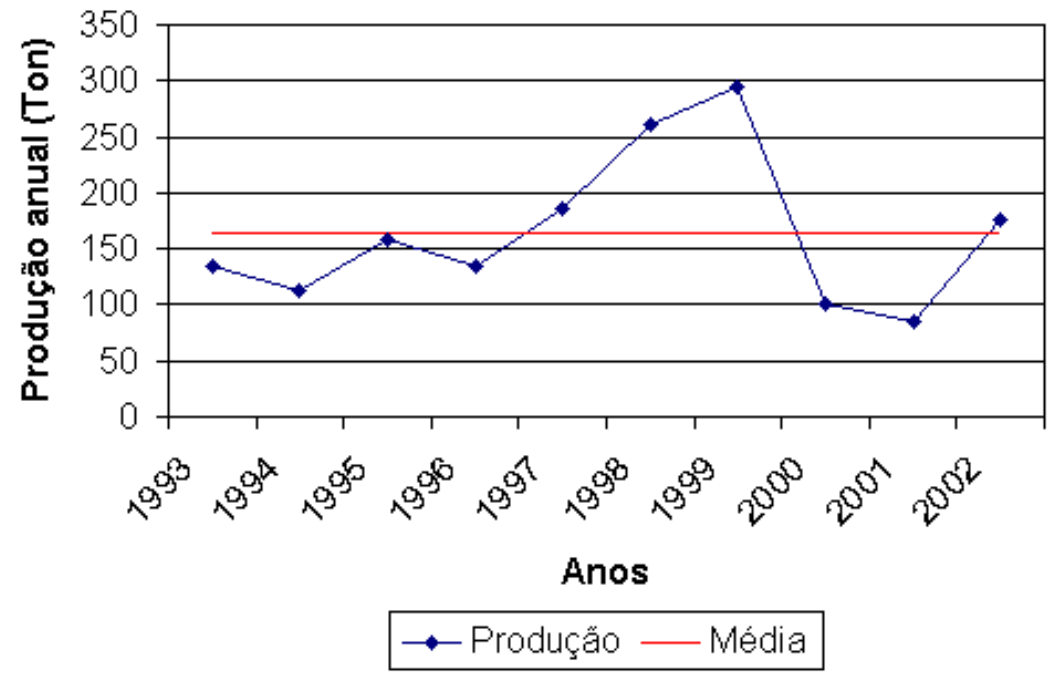

Figura 28 - Comportamento da produção anual de pescado em Canguaretama - 1993 a 2002

Fonte: IBAMA/CEPENE (1993 a 2002).

Já a recuperação da produção observada em 2002 pode ser explicada a partir da preocupação dos órgãos de fiscalização ambiental, influenciados pela repercussão 
ocorrida na mídia nos anos de 2000 e 2001, em relação à devastação dos manguezais, ao assoreamento de rios e à intensa ocupação das áreas litorânea do Estado, em função de atividades econômicas, a carcinicultura, o turismo e a produção salineira, que levaram a uma fiscalização mais rigorosa em relação aos projetos de carcinicultura e a pesca predatória no Estado e conseqüentemente no estuário do Curimataú/Cunhaú.

A queda na produção afetou diretamente a vida dos moradores que vivem exclusivamente da pesca no Canto do Mangue. Sobre a escassez de pescado nos últimos anos, a população local comenta suas conseqüências:

"Aqui cortaram muito o mangue. O peixe agora é muito pouco; o pescador vive morrendo de fome. Tem deles que passam a noite todinha pescando para pegar uma coisinha de nada. Não é mais como naquele tempo que os caranguejos andavam por todo canto. Por aqui se pegava o sururu, a ostra, o aratu. Agora essas coisas são muito pouca. Acho que quando a maré vem traz aquela água, com aquele produto dos viveiros e vai matando tudo. $O$ sururu está pouco. Eu nunca mais comi uma ostra grande. Por aqui não tem mais quase mangue para tirar [coletar] esses pescados. Para se pegar alguma coisa o pescador tem que ir para mais longe. Para o Francês ${ }^{20}$, acho que só tem pescados por onde as águas com os produtos usados nos viveiros não alcançam”.

Luiz, ex-presidente da Colônia de Pescadores.

A preocupação com os impactos causados pelo lançamento de efluentes, provenientes da carcinicultura, é constatada nas falas dos moradores. Pesquisadores como Coelho Júnior \& Schaeffer-Novelli (2000) mencionam que esses efluentes podem causar contaminação nos ecossistemas aquáticos por patógenos, hormônios, carrapaticidas, compostos químicos, resíduos alimentares e fertilizantes.

\footnotetext{
${ }^{20}$ Porto do Francês, ponto de pesca dos pescadores do Canto do Mangue.
} 
A queda na produção pesqueira apontada por pescadores locais e constatada na Figura 28 se deu, principalmente, devido ao declínio na produção de caranguejos do município, já que esse crustáceo contribui com $55 \%$ da produção pesqueira de Canguaretama.

A Figura 29 apresenta o comportamento da produção de caranguejo em Canguaretama. Para melhor análise, a série foi dividida em dois períodos, de 1993 a 1997 e de 1997 a 2002, sendo possível verificar a existência de dois comportamentos estatísticos distintos, havendo uma menor dispersão dos dados no primeiro período, apresentando uma média de 88,6 ton com um desvio padrão de 20,7 ton, ao passo que, no segundo período, a média é de 93,2 ton com um desvio padrão de 85,9 ton.

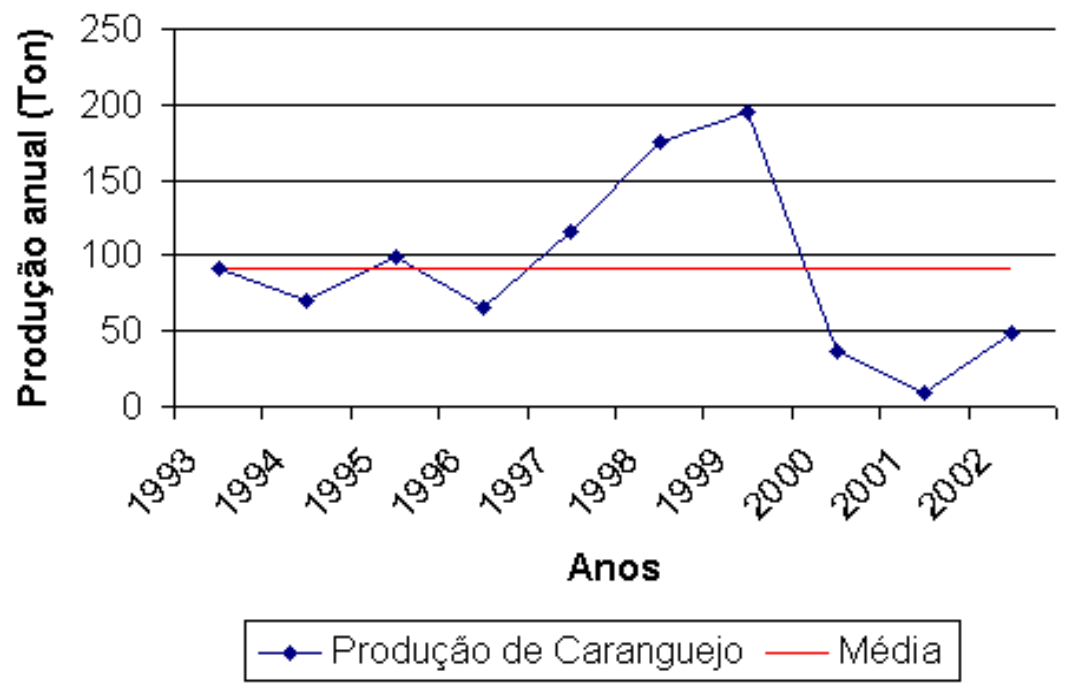

Figura 29 - Comportamento da produção anual de caranguejos em Canguaretama de 1993 a 2002

Fonte: IBAMA/CEPENE (1993 a 2002).

Fica evidenciado que houve um desequilíbrio na série, apesar das médias ficarem próximas. As dispersões ocorridas mostram que existem fatores de ordem biológica e ecológica, causados por práticas antropogênicas, que podem ter influenciado 
esse comportamento. Esse é o caso da estrutura produtiva de camarão em cativeiro, cujo aumento na produtividade tem sido bastante elevado nos últimos anos para atender à produção econômica em larga escala. Junto a esse fator pode-se adicionar, também, o aumento da captura de caranguejos no segundo período analisado.

O aumento na captura pode estar associado à redução da área de manguezal, fator que conseqüentemente leva ao adensamento populacional da espécie, afetando a capacidade de sustentação (ou seja, a máxima população de uma espécie particular que um dado ambiente pode suportar) e, por conseguinte, favorecendo as chances dos predadores (os catadores de caranguejos) capturarem um número maior de indivíduos sem aumentar o seu esforço.

No intervalo de 2000 a 2001 foi observada uma mortandade considerável de caranguejos no estuário do Curimataú/Cunhaú. A preocupação com a redução do estoque de caranguejo-uçá, em Canguaretama, foi mencionada na mídia nacional, em matéria apresentada no Jornal Nacional (Rede Globo de Televisão) de 16 de fevereiro de 2000.

"Milhares de caranguejos morrem (...) no Rio Grande do Norte, deixando sem trabalho mais de 400 famílias. Na região de mangue de Canguaretama, a $100 \mathrm{~km}$ [sic.] de Natal, a área afetada se estende por $10 \mathrm{~km}$. Em apenas 20 metros, os agentes do IBAMA contaram 16 caranguejos mortos. Essa é a época de reprodução, quando os caranguejos saem da toca para se acasalar. Os ficais do IBAMA recolheram amostras para análises". ${ }^{21}$

No Estado, essa mortandade também foi notificada, principalmente na mídia impressa. No entanto, não se tem registro das possíveis causas desse desequilíbrio ecológico. Em 2001, o jornal Tribuna do Norte publicou:

21 Sinopse dos telejornais em 16/02/2000. Globo - Jornal Nacional - 20h15. Disponível em http//www.radiobras.gov.br/anteriores/2000/sinopses-1602.htm $\neq 12$ - acesso em 02 de fev. 2004. 
"PRODUÇÄO de caranguejos do RN pode desaparecer (...) Caranguejos que vivem nos manguezais do Rio Grande do Norte correm o risco de desaparecerem do ecossistema; em função da ampliação do cultivo de camarão, os mangues estão sendo desmatados. A invasão do hábitat associada à intensa pesca ameaçam o crescimento e a reprodução do crustáceo" (2001).

Os comportamentos sazonais da produção de pescado mostrados nas Figuras 28 e 29, e os dados de produção de camarão em cativeiro de 1993 a 2002, permitiram mensurar quantitativamente a relação entre o aumento da produção de camarão em cativeiro no Estado e a redução da produção do estoque pesqueiro, particularmente, o estoque de caranguejo em Canguaretama. Foi possível correlacionar, com base nos dados quantitativos, as duas variáveis, chegando à constatação de uma correlação forte (76\%). Ou seja, há um sentido inverso: à medida que há um aumento na produção de camarão, ocorre queda na produção de caranguejo no município.

Essa pode ser analisada a partir das modificações no uso do território e dos recursos da área pesquisada, onde o modo de produção de subsistência, entendido como a pesca artesanal, passou a ceder o seu espaço de reprodução à produção industrial de camarão. Tal produção apóia-se na biotecnologia e volta-se para o atendimento das necessidades do mercado econômico mundial, sobretudo o abastecimento dos Estados Unidos e países da União Européia (França, Espanha, Itália e Bélgica).

A produção em larga escala numa economia de mercado desconsidera a busca de equilíbrio nas configurações territoriais. Não se pode separar a problemática ambiental da dimensão territorial, porque a apropriação desordenada do território pode levar a desequilíbrios de ordem ecológica. Em outros termos, a capacidade de absorção dos resíduos emitidos, no final de um dado processo produtivo, em um determinado ecossistema, poderá exceder a sua faixa de tolerância, ou seja, a amplitude ecológica.

As perturbações ambientais provocam conseqüências que assumem dimensões sócio-culturais afetando diretamente o modo de vida das populações humanas. Essas, muitas vezes, são constituídas por indivíduos que não usufruem as grandes vantagens do 
circuito de "mundialização" econômica, mas sofrem os efeitos predatórios da expansão do capital nos seus territórios de reprodução.

Além das conseqüências da carcinicultura, outro elemento a ser considerado como agravante na escassez de caranguejo diz respeito à coleta indiscriminada e à utilização de técnicas predatórias de captura.

"Aqui, agora, tem pouco caranguejo. O povo também contribuiu para acabar tudo, com o uso de umas redinhas. Inventaram umas redinhas que os caranguejos se engalhavam, depois andavam dizendo que elas [as redinhas] quando ficam podres [em decomposição] matavam os caranguejos. Outros dizem que foi a água dos viveiros de camarão e esses cortes no mangue [o corte da vegetação] e assim, ninguém sabe o que está acontecendo de fato”. José Geraldo, pescador.

Existe claramente uma preocupação dos moradores em relação às mudanças que vêm ocorrendo na área. Nos relatos aparecem elementos considerados como os principais responsáveis pela diminuição de pescado, sendo atribuídos às empresas de camarão, ao corte dos manguezais e à emissão dos efluentes no estuário. Já em relação aos membros da comunidade, é atribuído o uso de redinhas, técnica de captura proibida, que foi bastante utilizada por catadores de caranguejos na década de noventa, após contato com outros catadores advindos principalmente do litoral paraibano. Assim, essa técnica foi incorporada pelos catadores de Canguaretama.

Nas entrevistas, os moradores fazem referência ao processo de produção de camarão (a lavagem dos tanques e o lançamento das águas servidas) como uma preocupação coletiva, expressando as incertezas em relação aos produtos utilizados nas águas armazenadas nos tanques. Entretanto, fica clara a desinformação da população com relação ao processo produtivo, pois mesmo sabendo com precisão as etapas de produção, os aspectos ligados às informações tecnológicas ficam distantes do entendimento dos moradores do Canto do Mangue. 
“Eles usam um veneno, quer dizer eu não sei se é mesmo um veneno... É um produto que ninguém daqui sabe o que é de verdade. Como você sabe têm muitos peixes que são inimigos do camarão [predadores]. Então para eles [se refere aos criadores] se livrarem de certos tipos de peixes usam o veneno. Coloca o veneno, para matar os micróbios [larvas de predadores] e depois colocam as larvas do camarão, pois já mataram os filhotes de peixe, de siri e acho que também matam caranguejos. Por sinal, isto está sendo muito ruim para nós pescadores, porque se matar os peixes pequenos, os filhotes, depois não se tem mais peixes grandes. E como nós vamos ficar?”

José Campos, pescador aposentado.

Nesta pesquisa, deixo claro que não tive a intenção de analisar com precisão as causas da mortandade de caranguejos, até porque não propus essa temática como objetivo específico, mas sim em associação ao comportamento da produção pesqueira no município. Mas, diante da relevância do tema, se fazem necessárias pesquisas biológicas, ecológicas, oceanográficas e em áreas afins, de forma mais aprofundada. É uma lacuna a ser preenchida com urgência, em função das implicações relativas às avaliações legais necessárias para a instalação da carcinicultura e, assim, se fazer uso racional e em longo prazo dos recursos naturais dos ambientes costeiros.

Fazendo alusão a Leff (2000), observa-se que a natureza aos poucos vai deixando de ser fonte de simbolização, suporte e potencial de riqueza material e espiritual dos povos, para se converter em fonte de matéria-prima que alimenta a acumulação do capital em escala mundial. Essa apropriação da natureza por pequenos grupos termina por afastar as populações locais de suas práticas, levando à perda de saberes seculares.

Embora a comunidade do Canto do Mangue ainda esteja integrada ao seu ambiente natural, é preciso ressaltar que o processo de mudança ocorrido em sua 
trajetória recente termina por alterar as relações de territorialidade desta população humana. Enquanto no passado havia o usufruto dos recursos, sem que houvesse uma preocupação com a questão do território de pesca, agora a vivência dessa preocupação se faz presente na vida dos pescadores artesanais, que passaram a perder seus territórios de reprodução econômica, social e cultural para a iniciativa privada.

A dificuldade crescente na captura de pescado, principalmente das espécies de maior valor comercial, tem levado ao abandono da atividade pesqueira no Canto do Mangue. Na pesquisa de campo, pude observar uma busca da população por trabalhos na carcinicultura. $\mathrm{O}$ reconhecimento das empresas que oferecerem um salário fixo aos funcionários e os direitos trabalhistas, além de outros auxílios, leva à procura de postos de trabalhos nesse setor.

Entre os moradores que possuem parentes trabalhando nas empresas de camarão, constatei unanimidade em relação ao reconhecimento dos benefícios que esses salários fixos acrescentaram à vida das suas famílias. No Canto do Mangue, é motivo de orgulho para os pais ter ao menos um dos filhos como funcionário na carcinicultura.

Embora os usos tradicionais dos recursos ainda venham se mantendo, e discretas incorporações técnicas venham ocorrendo ao longo dessas duas décadas analisadas, a produtividade reduzida do pescado termina por alterar a dinâmica local conduzindo ao abandono da pesca, como afirmaram os moradores da comunidade. Conseqüentemente, as alterações no modo de vida podem estar contribuindo para a perda dos saberes acumulados por essa população ao longo dos anos.

Esses saberes mantiveram a sobrevivência de inúmeros povos ao longo dos tempos, apresentando vantagens valiosas, pois foram eles que contribuíram para manter a biodiversidade. Assim, geração de divisas com carcinicultura no Estado poderia ser destinada a programas de gerenciamento e gestão das áreas ocupadas, considerando os saberes e interesses das comunidades locais em relação aos seus ambientes, bem como projetos de educação ambiental, destinados à comunidade, no intuito de esclarecer os impactos gerados pelo uso de técnicas predatórias de pesca na captura, entre outros fatores. 
A implantação de medidas como essas, entretanto, caminha a passos lentos, uma vez que perpassam pela necessidade de políticas voltadas para o reconhecimento da participação comunitário na elaboração de metas que levem ao desenvolvimento da carcinicultura, diante da sua importância econômica no Estado, sem por em risco a sustentabilidade da região. 


\section{CONCLUSÕES}

O local é o lugar de "raiz". As populações humanas criam significados, símbolos e imagens que forjam as identidades e as aderências que fixam o indivíduo e o seu grupo social a um espaço particular. Este é resultado da memória, da produção e da técnica, mas, acima de tudo, das vidas dos membros do grupo.

No caso particular do Canto do Mangue, esse espaço apresenta as seqüelas dos processos produtivos de outrora e atuais, entendidas como as áreas devastadas pelas salinas e pelos resíduos finais do processo produtivo da carcinicultura.

As condições de vida da população dessa comunidade vêm sendo direcionadas pela dinâmica do capital, que aproveita as potencialidades dos recursos estuarinos para o desenvolvimento da carcinicultura.

A partir de 1980 passou a ocorrer uma especulação imobiliária nas áreas do estuário do rio Cunhaú/Curimataú, contribuindo para a recuperação do capital das famílias "proprietárias" dessas terras e levando a mudanças no uso dos recursos e dos territórios pesqueiros, como o rompimento da agricultura de subsistência e o abandono da pesca artesanal.

$\mathrm{O}$ uso dos recursos é realizado pelos moradores, com base no respeito às normas de conduta dos membros da comunidade numa ampla rede social, considerando relações de parentesco, divisão do trabalho, hábitos alimentares, contribuindo para favorecer atitudes de solidariedade e para a formação da identidade do grupo.

A perda dos territórios de (re)produção dessa população reflete-se na queda da produção de pescado, sobretudo na baixa de caranguejo-uçá, em função de fatores relacionados com a degradação ambiental: corte dos manguezais, emissão de efluentes 
provenientes dos viveiros de camarão, além da utilização de técnicas predatórias de captura.

A infra-estrutura básica destinada à comunidade por parte do poder público (acesso à água tratada, energia elétrica, pavimentação), nas últimas duas décadas, deu uma configuração urbana à comunidade, melhorando aspectos da vida dos moradores locais.

Mas essas mudanças não solucionaram uma realidade estagnada no tempoespaço, ou seja, a segregação sócio-econômica das populações que habitam as proximidades das áreas de manguezais, comuns em toda a faixa intertropical do Planeta. $\mathrm{O}$ acesso a direitos básicos do cidadão (educação, saúde, moradia, alimentação adequada) caminha timidamente. Com ressalvas aos direitos trabalhistas adquiridos pelos pescadores associados à Colônia e por aqueles inseridos na carcinicultura.

A Colônia de Pescadores não apresenta uma proposta de diálogo entre pescadores, poder público local e empresários, no sentido de buscarem juntos soluções que permitam realmente o uso sustentável dos recursos litorâneos nessa área.

A rapidez como estão acontecendo as mudanças na dinâmica da comunidade chega a ser preocupante, uma vez que ameaça o conjunto de saberes aplicados à pesca. Esses saberes têm contribuído para o uso e manejo dos recursos pesqueiros de forma sustentável ao longo dos tempos.

As atividades econômicas voltadas para o mercado, como é o caso da carcinicultura, se afastam com freqüência de aspectos da tradição e cultura inerentes aos ecossistemas. E, assim, afastam as populações tradicionais das suas práticas, resultando na perda de uma importante contribuição para o gerenciamento dos recursos locais.

Não é possível desconsiderar a importância econômica da carcinicultura no Estado e nem os avanços tecnológicos que propiciaram a sua implantação em vários países do mundo. Mas é preciso, também, considerar o conhecimento acumulado pela população local e a conservação ambiental. O diálogo entre esses dois modos distintos de explicar o mundo poderá responder às questões relacionadas aos problemas de nosso tempo e apontar alternativas de soluções. 


\section{REFERÊNCIAS BIBLIOGRÁFICAS}

ALLUT, A.G. O conhecimento dos especialistas e seu papel no desenho de novas políticas pesqueiras. In: DIEGUES, A.C. (Org.) Etnoconservação: novos rumos para a conservação da natureza. São Paulo: Hucitec; NUPAUB/USP, 2000. cap.5, p.101-123.

ALMEIDA, M. da C. de. Complexidade e cosmologias da tradição. Belém: DUEPA, 2001a. 145p.

ALMEIDA, M. da C. de. Técnicas de previsão climática no Nordeste do Brasil: uma ciência "neolítica" no século XX. In: CONGRESSO LUSO-BRASILEIRO DE HISTÓRIA DA CIÊNCIA E DA TÉCNICA, 1., Évora-Aveiro, 2001. Actas. Évora/Aveiro: Centro de Estudos de História e Filosofia da Ciência da Universidade de Évora, 2001b. p.577-584.

ALVES, R.R. da N.; NISHIDA, A.K. A ecdise do caranguejo-uçá, Ucides cordatus L. (DECAPODA, BRACHYURA) na visão dos caranguejeiros. Interciências, v.27, n.9, p.1-19, 2002.

ASSOCIAÇÃO BRASILEIRA DE CRIADORES DE CAMARÃO. Agronegócio do camarão marinho cultivado - censo do cultivo de camarão no Brasil. Dados de 1993 a 2002. http//www.abccam.com.br (05 jan. 2004) 
BALANDIER, G. A desordem, elogio do movimento. Trad. S. Martins. Rio de Janeiro: Bertrand Brasil, 1997. 261p.

BANDEIRA, F.P.S. de F. Construindo uma epistemologia do conhecimento tradicional: problemas e perspectivas. In: ENCONTRO BAIANO DE ETNOECOLOGIA E ETNOBIOLOGIA, 1., Feira de Santana, 1999. Anais. Feira de Santana: UEFS, 2001. p.109-133.

BARRETO, J. J. Canguaretama centenária. Natal: Fundação José Augusto, 1985. $144 p$.

BECKER, H.S. Métodos de pesquisas em ciências sociais. 4.ed. Trad. de M. Estevão, R. Aguiar. São Paulo: Hucitec, 1999. 178p.

BEGOSSI, A. Áreas, pontos de pesca, pesqueiros e territórios na pesca artesanal. In: BEGOSSI, A. (Org.) Ecologia de pescadores da Mata Atlântica e da Amazônia. São Paulo: Hucitec, No prelo. 375p. cap.7, p.256-287

BEGOSSI, A. Fishing sport and sea tunere: incipient forms of local manegement in atlantic forest coastal communities. Human Ecology, v.23, n.3, p.387-406, 1995.

BEGOSSI, A. The fishers and buyer from Búzios Island (Brazil): kin ties and modes of production. Ciência e Cultura, v.48, n.3, p.142-147, 1996.

BEGOSSI, A.; HANAZAKI, N.; SILVANO, R. A. M. Ecologia Humana, Etnoecologia e Conservação. In: AMORROZO, M.C. de M.; MING, L. C.; SILVA, S.P. (Ed.) Método de coleta e análise de dados em etnobiologia, etnoecologia e disciplinas correlatas. Rio Claro/SP: UNESP/CNPq, 2002. 204p. cap.4, p.93-128.

BRASIL é o primeiro no ranking latino. Diário de Natal, Natal, 30 mar. 2003. p.4. 
BRASIL. Constituição (1988) Constituição da República Federativa do Brasil. 4.ed. São Paulo: Saraiva, 1990.169p. Organização dos textos, notas remissivas e índices por Juarez de Oliveira. (Série Legislação Brasileira).

BRASIL. Lei no 8.287, de dezembro de 1991. Diário Oficial, Brasília, DF, 23 dez. 1991. Dispõe sobre a concessão do benefício de seguro desemprego a pescadores artesanais, durante os períodos de defeso.

BRÜSEKE, F.J. O problema do desenvolvimento sustentável. In: CAVALCANTI, C. (Org.) Desenvolvimento e natureza: estudos para uma sociedade sustentável. São Paulo: Cortez; Recife: Fundação Joaquim Nabuco, 1995. 429p. cap.2, p.29-39.

CAPORALI, C.R. Da riqueza das nações à ciência das riquezas. São Paulo: Loyola, 1995. 230p.

CARCINICULTURA ameaça mangues. Tribuna do Norte, Natal, 11 nov. 2001. p.3.

CARDOSO, E.S. Pescadores artesanais, natureza, território e movimento social. São Paulo, 2001. 139p. Tese (Doutorado) - Faculdade de Filosofia, Letras e Ciência Humanas, Universidade de São Paulo.

CASCUDO, L. da C. Jangada: uma pesquisa etnográfica. Rio de Janeiro: Ministério da Educação e Cultura, 1957. 181p.

CASCUDO, L.da C. História do Rio Grande do Norte. Ministério da Educação e Cultura: Rio de Janeiro: 1955. 1v.

CASTRO, F.; BEGOSSI; A. Ecology of fishing on the Grande River (Brazil): technology and territorial rights. Fisher Research, n.23, p.361-373, 1995. 
CASTRO, J. de. Homens e caranguejos. Rio de Janeiro: Civilização Brasileira, 2001. $188 \mathrm{p}$.

CENTRO DE PESQUISA E GESTÃO DE RECURSOS PESQUEIROS DO LITORAL DO NORDESTE. Boletim estatístico da pesca marítima e estuarina do Nordeste do Brasil - 2002. Tamandaré: CEPENE, 2003. p.11-21.

CENTRO DE PESQUISA E GESTÃO DE RECURSOS PESQUEIROS DO LITORAL DO NORDESTE. Boletim estatístico da pesca marítima e estuarina do Nordeste do Brasil - 2000. Tamandaré: CEPENE, 2001. p.48-53.

CENTRO DE PESQUISA E GESTÃO DE RECURSOS PESQUEIROS DO LITORAL DO NORDESTE. Boletim estatístico da pesca marítima e estuarina do Nordeste do Brasil - 2001. Tamandaré: CEPENE, 2002. p.34-53.

CENTRO DE PESQUISA E GESTÃO DE RECURSOS PESQUEIROS DO LITORAL DO NORDESTE. Boletim estatístico da pesca marítima e estuarina do Nordeste do Brasil - 1999. Tamandaré: CEPENE, 2000. p.55-60.

CLAUZET, M. Conhecimento local e atividade pesqueira na Enseada do Mar Virado, Ubatuba litoral norte, SP. São Paulo, 2003. 123p. Dissertação (Mestrado) Interunidades, Universidade de São Paulo.

COELHO JUNIOR, C.; SCHAEFFER-NOVELLI, Y.S. Considerações teóricas e práticas sobre o impacto da carcinicultura nos ecossistemas costeiros, com ênfase no ecossistema de manguezal. (compact disc). In: CONFERÊNCIA INTERNACIONAL MANGROVE; SUSTENTABILIDADE DE ESTUÁRIOS E MANGUEZAIS: DESAFIOS E PERSPECTIVAS, Recife, 2000. Anais. Recife: UFRPE, 2000. 
CORRÊA, R. M. Pensando a geografia brasileira no começo do século XXI. Sociedade e Território, v.15, n.2, p.9-16, jun./dez., 2001.

CORREIA FILHO, J.; CANEJO, M. A ecologia sob controle. Panorama Rural, v.57, n.11, p.69-74, nov, 2003.

COSTA NETO, E.M.; MARQUES, J.G.W. Atividade de pesca desenvolvidas por pescadores na comunidade de Siribinha, município de Conde, Bahia: uma abordagem etnoecológica. Sitientibus, v.1, n.1, p.71-78, 2001. (Série - Ciências Biológicas).

CRUZ. D. Como bons timoneiros. In: CASTRO, G.; CARVALHO, E. A.; ALMEIDA, M. C. (Org.) Ensaios de complexidade. 3 ed. Porto Alegre: Sulinas, 2002. 246p. cap 17. p. $168-178$.

D’AMBrosio, U. Introdução. In: SILVA, C. A da.; MENDES, I. A. (Org.) Tereza Vergani - a surpresa do mundo: ensaios sobre cognição, cultura e educação. Natal: Editorial Flecha do Tempo, 2003. p. 16-20.

DANI, S.U. Ecologia e organização do ambiente antrópico: novos desafios. Belo Horizonte: Fundação Acangau, 1994. 191p.

DIEGUES, A.C. Pescadores, camponeses e trabalhadores do mar. São Paulo: Ática, 1983. $287 \mathrm{p}$.

DIEGUES, A.C. A pesca artesanal no litoral brasileiro: cenários e estratégias para sua sobrevivência. São Paulo: IO/USP/FFord/IUCN, 1988. 44p.

DIEGUES, A.C. Povos e mares: leituras em sócio-antropologia marítima. São Paulo, NUPAUB/USP, 1995. 269p. 
DIEGUES, A.C. Tradição marítima e oralidade: pesca de marcação e mestrança em Galinhos Rio Grande do Norte - Brasil. Revista do Programa de Pós-Graduação em História da Pontifícia Universidade Católica, n.22, jun., p.389-400, 2001.

DIEGUES, A.C.; NOGARA, P. O nosso lugar virou parque: um estudo sócioambiental do Saco Mamangá - Paraty-Rio de Janeiro. 2.ed. São Paulo: NUPAUB/USP, 1999. 165p.

DIEGUES, A.C.; ARRUDA, R.S.V. (Org.) Saberes tradicionais e biodiversidade no Brasil. Brasília: Ministério do Meio Ambiente; São Paulo: USP, 2001. 176p. (Biodiversidade, 4).

FEDERAÇÃO DAS INDÚSTRIAS DO ESTADO RIO GRANDE DO NORTE. Panorama da carcinicultura no Brasil: Nordeste e outros estados, arrecadação do ICMS-RN. Natal: FIERN, 2000. 1v.

FEENY, D.; BERKES, F.; MACCAY, B. et al. The tragedy of the Commons: twentytwo years later. Human Ecology, v.18, n.1, p.1-9, 1990.

FENZL, N. O conceito de desenvolvimento sustentável em sistemas abertos. Poematropic, v.1, n.1, p.34-42, jan./jun., 1998.

FONSECA, J.S.; MARTINS, G.A; TOLEDO, G.L. Estatística aplicada. São Paulo: Atlas, 1986. 225p.

GALVÃO, J. de A. Impactos ambientais: uma proposta de zoneamento de uso e ocupação do solo em Barra do Cunhaú no município de Canguaretama/RN. João Pessoa, 2000. 1v. Dissertação (Mestrado) - Centro de Ciências Exatas e da Natureza, Universidade Federal da Paraíba. 
GLOBAL AQUACUltURe ALLIANCE - GAA. Proposta de estratégica setorial sobre resíduos de antibióticos no camarão de cultivo. Trad. Associação Brasileira de Criadores de Camarão. European Seafood Exhibition, Bruxelas, 2002. http://www.abccam.com.br/revista/Agosto2002/proposta_residuos_antibioticos.htm (16 de set.2003).

HADIN.G. The tragedy of the coommons. Science, v.162, p.1243-1248, 1968.

HAESBAERT. R. Territórios alternativos. Niterói: EdUFF; São Paulo: Contexto, 2002. $186 \mathrm{p}$.

HANAZAKI, N. Preferências e tabus alimentares entre pescadores do litoral paulista: particularidades do conhecimento local. In: ALBUQUERQUE, U.P.; ALVES, A.G.C.; SILVA, A.C.B.L. et al (Org.) Atualidades em etnobiologia e etnoecologia. Recife: Sociedade Brasileira de Etnobiologia e Etnoecologia, 2002. cap.4, p. 57-73.

IBAMA aplica 53 autos em carcinicultores. Tribuna do Norte, Natal, 21 nov. 2001. p.12.

INFORMATIVO TÉCNICO DA REVISTA GLEBA. Cultivo do camarão marinho é opção de exploração econômica. http//www.cna.org.br/gleba02/marabr/carcinicultura.htm (26 ago. 2002).

INSTITUTO BRASILEIRO DO MEIO AMBIENTE E RECURSOS NATURAIS RENOVÁVEIS. Boletim estatístico da pesca marítima e estuarina no Rio Grande do Norte. Natal: IBAMA, 1998. p.23-31.

INSTITUTO BRASILEIRO DO MEIO AMBIENTE E RECURSOS NATURAIS RENOVÁVEIS. Boletim estatístico da pesca marítima e estuarina no Rio Grande do Norte. Natal: IBAMA, 1997. p.11-20. 
INSTITUTO BRASILEIRO DO MEIO AMBIENTE E RECURSOS NATURAIS RENOVÁVEIS. Boletim estatístico da pesca marítima e estuarina no Rio Grande do Norte. Natal: IBAMA, 1996. p.16-24.

INSTITUTO BRASILEIRO DO MEIO AMBIENTE E RECURSOS NATURAIS RENOVÁVEIS. Boletim estatístico da pesca marítima e estuarina no Rio Grande do Norte. Natal: IBAMA, 1995. p.13-21.

INSTITUTO BRASILEIRO DO MEIO AMBIENTE E RECURSOS NATURAIS RENOVÁVEIS. Boletim estatístico da pesca marítima e estuarina no Rio Grande do Norte. Natal: IBAMA, 1994. p.18-30.

INSTITUTO BRASILEIRO DO MEIO AMBIENTE E RECURSOS NATURAIS RENOVÁVEIS. Boletim estatístico da pesca marítima e estuarina no Rio Grande do Norte. Natal: IBAMA, 1993. p.17-29.

INSTITUTO DE DESENVOLVIMENTO ECONÔMICO E MEIO AMBIENTE DO RIO GRANDE DO NORTE. Ecossistemas do Rio Grande do Norte. Natal: IDEMA, 2000. ( Manguezal, 6).

INSTITUTO DE DESENVOLVIMENTO ECONÔMICO E MEIO AMBIENTE DO RIO GRANDE DO NORTE. Informativo municipal: Canguaretama. Natal, v.5, p.1-15, 1999.

INSTITUTO DE DESENVOLVIMENTO ECONÔMICO E MEIO AMBIENTE DO RIO GRANDE DO NORTE. Licenças ambientais da atividade de carcinicultura: estuário do rio Curimataú/Cunhaú, 2004.

KORMONDY, E. J.; BROWN, D. E. Ecologia humana. Trad. M. Blum. São Paulo: Atheneu, 2002. 503p. 
LEFF, E. Ciencias sociales y formacion ambiental. Barcelona: Editora Gedisa, 1994. $83 \mathrm{p}$.

LEFF, E. Educação ambiental e desenvolvimento sustentavel. In: Verde REIGOTA, M. (Org.) Verde Cotidiano: o meio ambiente em discussão. Rio de Janeiro: DP\&A, 1999. cap. 6, p. 111-128.

LEFF, E. Ecologia, capital e cultura: racionalidade ambiental, democracia participativa e desenvolvimento sustentável. Trad. J. Esteves da Silva. Blumenau: EDIFURB, 2000. 373p.

LEFF, E. Epistemologia ambiental. Trad. S. Valenzuela. São Paulo: Cortez, 2001a. 240p.

LEFF, E. Saber ambiental: sustentabilidade, racionalidade, complexidade e poder. Trad. L.M.E. Orth. Petrópolis: Vozes, 2001b. 343p.

LÉVI-STRAUSS, C. O pensamento selvagem. Campinas: Papirus, 1989. 323p.

LIMA, T.; QUINAMO, T. Características sócio-econômicas. In: BARROS, H. M. (Coord.) Gerenciamento participativo de estuários e manguezais. Recife: EDUFPE, 2000. cap. 14, p.18-225.

LOPES NETO, G. Carcinicultura: cultivo do camarão. Século. n.2, p.100-101, s.d. (Fundação Cultural Padre João Maria).

LÜDKE, M.; ANDRÉ, M. Pesquisa em educação: abordagens qualitativas. São Paulo: EPU, 1986. 99p. 
MACEDO, R.S. A etnopesquisa crítica e multirreferencial nas ciências humanas e na educação. Salvador: UFBA, 2000. 297p.

MALDONADO, S.C. Botes e tripulação de iguais: ideário e instrumentos de trabalho na pesca marítima. In: ALBURQUERQUE, U.P.; ALVES, A.G.C.; SILVA, A.C.B.L. et al (Orgs.) Atualidades em etnobiologia e etnoecologia. Recife: Sociedade Brasileira de Etnobiologia e Etnoecologia, 2002. cap.3, p.45-55.

MALDONADO, S.C. Pescadores do mar. São Paulo: Ática, 1986. 77p. (Série Princípios).

MARQUES, J.G. Dinâmica cultural e planejamento ambiental: sustentar não é congelar. In: BASTOS-FILHO, J.B.; AMORIM, N.F.M.; LAGES, V.N. (Org.) Cultura e desenvolvimento: a sustentabilidade cultural em questão. Maceió: PRODEMA/UFAL, 1999. cap.3, p.47-68.

MARQUeS, J.G. Pescando pescadores: ciência e etnociência em uma perspectiva ecológica. 2.ed. São Paulo: NUPAUB/ USP, 2001. 258p.

MARQUES, J.G. O olhar (des)multiplicado: o papel do interdisciplinar e do qualitativo na pesquisa etnobiológica e etnoecológica. In: AMORROZO, M.C. de M.; MING, L.G.; SILVA, S.P. (Ed.) Método de coleta e análise de dados em etnobiologia, etnoecologia e disciplinas correlatas. Rio Claro/SP: UNESP/CNPq, 2002. cap.2, p.31-45.

MELO JÚNIOR, G. Poluição por metais pesados em sedimentos de fundo do estuário do rio Curimataú, litoral sudeste do Rio Grande do Norte. In: SIMPÓSIO DE GEOLOGIA DO NORDESTE, 18., Recife, 2000. Resumos. Recife: SBG - Núcleo Nordeste, 2000. p.245. (Boletim, 16). 
MELO JÚNIOR, G. Procedência dos metais pesados do Curimataú. Diário de Natal. Da Vinci, Natal, 24 nov. 2001. p.5.

MELO JÚNIOR, G. Metais pesados no estuário do rio Curimataú, litoral sudeste do Rio Grande do Norte. In: MANGROVE/2003: CONNECTING RESEARCH AND PARTICIPATIVE MANAGEMENT OF ESTUARIES AND MANGROVES, Salvador, 2003. Abstracts. Salvador: UFBA, 2003. p.267.

MILARÉ, É. Direito do ambiente:doutrina, pratica, jurisprudência, glossário. 2.ed. São Paulo: Editora Revista dos Tribunais, 2001. 783p.

MORÁN, E.F. A ecologia humana das populações da Amazônia. Petrópolis: Vozes, 1990. 367p. (Coleção Ecologia \& ecosofia).

MORIN, E. Os sete saberes necessários à educação do futuro. Trad. C.E.F. da Silva e J. Sawaya. 2.ed. São Paulo: Cortez; Brasília, DF: UNESCO, 2000. 118p.

MORIN, E.; KERN, A.B. Terra pátria. Trad. A.P. da Silva. 2.ed. Lisboa: Instituto Piaget, 2001. 209p.

MOURA, M.C.A.; TEIXEIRA, W.F.P. Lagoa do Piató: fragmentos de uma história. Natal: CCHLA/UFRN, 1993. 146p. (Coleção Humanas, Letras, 08).

MOURÃO. J. da S. Classificação e ecologia de peixes estuarinos por pescadores do estuário do Rio Mamanguape, PB. São Carlos, 2000. 131p. Tese (Doutorado) Centro de Ciências Biológicas e da Saúde, Universidade Federal de São Carlos.

NORDI, N. A captura do caranguejo-uçá (Ucides cordatus) durante o evento reprodutivo da espécie: o ponto de vista dos caranguejeiros. Revista Nordestina de Biologia, v.1, n.9, p.41-47, 1994. 
NORDI, N. O processo de comercialização do caranguejo - uca (Ucides Cordatus) e seus reflexos na atitude de coleta. Revista Nordestina de Biologia. v.1, n.10, p.3946, 1995.

ORGANIZAÇÃO DAS NAÇÕES UNIDAS. Comissão mundial sobre meio ambiente e desenvolvimento das Nações Unidas. Nosso futuro comum. 2.ed. Rio de Janeiro: Fundação Getúlio Vargas, 1991. 430p.

PEREZ, L. R-M. Métodos estadísticos de investigación em lãs ciências sociales: tecnicas no paramétricos. Madrid: Editorial AC, 2000. 121p.

PINHEIRO, M.A.A.; HATTORI, G.Y.; FISCARELLI, A.G. et al. Época de acasalamento e desova do caranguejo uçá, Ucides cardatus (Linnaus, 1763) (Crustácea, Brachyura, Ocypodidae). In: MANGROVE/2003: CONNECTING RESEARCH AND PARTICIPATIVE MANAGEMENT OF ESTUARIES AND MANGROVES, Salvador, 2003. Abstracts. Salvador: UFBA, 2003. p.133.

PONTES; C.S.; ARRUDA, M. de F. Conhecer o comportamento do camarão pode otimizar o cultivo. Diário de Natal. Da Vinci, Natal, 29 dez. 2001. p.05.

POSEY, D. Etnobiologia e ciências de folk: uma importância para a Amazônia. Tubinger Geographische Studien, n.95, p.95-108, 1987.

POSEY, D. Interpretando e utilizando a "realidade" dos conceitos indígenas: o que é preciso aprende dos nativos? In: DIEGUES, A.C.; MOREIRA, A.C.C. (Org.) Espaços e recursos naturais de uso comum. São Paulo: NUPAUB/USP, 2001. cap 12, p.278-294. 
PRIGOGINE, I. Ciência razão e paixão. In: CARVALHO, E. A.; ALMEIDA. M. da C. (Org.) Ciência, razão e paixão. Trad. E. A. Carvalho; I. Hetzel; L.M. Garda e M. Macedo. Belém: EDUEPA. 2001. cap.9, p.87-102.

PRIMAVERA, J. H. Intensive prawn farming in the Phillipines: ecological, social and economic implications. Ambio. n., 20, p. 28-33, 1993.

PRODUÇÃO de caranguejo no RN pode desaparecer dentro de dois anos. Tribuna do Norte, Natal, 03 mar. 2003. p.2.

PROJETO DE AMPARO AO PEQUENO PRODUTOR. Manual de orientação para elaboração de subprojetos comunitários. Natal: Secretária de Trabalho e Ação Social, 1997. 16p.

QUARESMA, F.P. A pesca artesanal de Canguaretama, RN. Natal, 1987. 22p. Monografia (Graduação) - Centro de Ciências Humanas, Letras e Artes, Universidade Federal do Rio Grande do Norte.

QUEIROZ, M.I.P. de. Relatos orais: do indizível ao dizível. Revista Ciência e Cultura, v.39, n.3, p.272-286, 1987.

RAMIRES, M.; BARRELA, W. Ecologia da pesca artesanal em população caiçara de Juréia - Itatins, São Paulo, Brasil. Interciência, v.28, n.4, p.208-213, 2003.

REDE de laboratório mapeará genoma do camarão no Brasil. http//www.ambientebrasil.com.Br/notícias/index.php3?action+ler\&id+10012 mar. 203). 
RIO GRANDE DO NORTE (Estado). Secretaria da Agricultura e Pesca. Plano de desenvolvimento sustentável para a carcinicultura. Cluster do camarão do Rio Grande do Norte: diretrizes para as principais ações do desenvolvimento da carcinicultura. Natal: GCL Editora, 2001. 72p.

SACHS, I. Ecodesenvolvimento: crescer sem destruir. Trad. E. Araújo. São Paulo: Vértice, 1986. 207p. (Terra dos homens).

SACHS, I. Debates. In: VIEIRA, P.F.; RIBEIRO, M.A.; FRANCO, R.M. et al (Org.) Desenvolvimento e meio ambiente no Brasil: a contribuição de Ignacy Sachs. Porto Alegre: Pallotti, 1998b. cap.1, p.57-61.

SACHS, I. Do crescimento econômico ao ecodesenvolvimento. In: VIEIRA, P.F.; RIBEIRO, M.A.; FRANCO, R.M. et al (Org.) Desenvolvimento e meio ambiente no Brasil: a contribuição de Ignacy Sachs. Porto Alegre: Pallotti, 1998b. cap.2, p.161-164.

SANTOS, B.S. Um discurso sobre as ciências. 11 ed. Porto: Edições Afrontamento, 1999. 58p. (História e Idéias).

SANTOS, B.S. Para um novo senso comum: a ciência, o direito e a política na transição paradigmática. 3 ed. São Paulo: Cortez, 2001. 1v.

SANTOS, B.S. O mundo resiste. Revista Caros Amigos, n.78, p.34-38, set., 2003.

SANTOS, B.V.; RODRIGUES, C. Introdução: para ampliar o cânone da produção. In: SANTOS, B.S. (Org.) Produzir para viver: os caminhos da produção não capitalista. Trad. V. Ferreira. Rio de Janeiro: Civilizações Brasileiras, 2002. v.2, cap.1, p.23-77. 
SCHAEFFER-NOVELLI, Y.; CINTRÓN-MOLERO, G.; SOARES, T. et al. Brazilian mangroves. Aquatic Ecosystem Health and Management, n.3, p.561-570, 2000.

SILVA, A.F. da. O zoneamento ecológico-econômico como instrumento de gestão do território: o caso do estuário do Curimataú/Cunhaú (RN) e seu entorno. Rio de Janeiro, 2000. 185p. Tese (Doutorado) - Instituto de Geociências, Universidade Federal do Rio de Janeiro.

SILVA, D.C. da. O simbolismo dos tabus alimentares como linguagem social. Natal, 1999.150p. Dissertação (Mestrado) - Centro de Ciências Humanas, Letras e Artes, Universidade Federal do Rio Grande do Norte.

SILVA, M.R. da; GARAVELLO, M.E.de P.E. Tradição e oralidade: pesca estuarina em Canguaretama, Rio Grande do Norte - Brasil. In: SIMPÓSIO DE ETNOBIOLOGIA E Etnoecologia dA REgIÃO SUL, 1., Florianópolis, 2003. Anais. Florianópolis: SBEE, 2003a. p. 259-269.

SILVA. M.R. da; GARAVELLO, M.E.de P.E. Pescadores artesanais do município de Canguaretama (RN): novas atividades econômicas. In: MANGROVE/2003: CONNECTING RESEARCH AND PARTICIPATIVE MANAGEMENT OF ESTUARIES AND MANGROVES, Salvador, 2003. Abstracts. Salvador: UFBA, 2003b. p.407.

SOUZA, M.R.; BARRELA, W. Conhecimento popular sobre peixes numa comunidade caiçara da Estação Ecológica de Juréia - Itatins/SP. Boletim do Instituto de Pesca. São Paulo, v.2, n.27, p.123-130, 2001.

THOMPSON, P. História oral e contemporaneidade. Trad. A. Zhouri e L.M.L. Pereira. Revista da Associação Brasileira de Historia Oral, n.5, p.9-23, jun., 2002. 
TRIVIÑOS, A.N.S. Introdução à pesquisa em ciências sociais: a pesquisa qualitativa em educação. São Paulo: Atlas, 1987. 175 p.

VANNUCCI, M. Os manguezais e nós: uma síntese de percepções. Trad. D. NavasPereira. São Paulo: EDUSP, 1999. 233p

VIERTLER, R.B. Método antropológico como ferramenta para estudos em etnobiologia e etnoecologia. In: AMORROZO, M.C. de M.; MING, L.C.; SILVA, S.P. (Eds.) Método de coleta e análise de dados em etnobiologia, etnoecologia e disciplinas correlatas. Rio Claro: UNESP/CNPq, 2002. cap.1, p.11-29.

VIVEIROS ameaçam área de mangues. Tribuna do Norte, Natal, 26 set. 2001. p.5.

WALTER, T. Ecologia da pesca artesanal no Lago Paranoá, Brasília - DF. São Carlos, 2000. 227p. Dissertação (Mestrado) - Escola de Engenharia de São Carlos, Universidade de São Paulo.

WOORTMANN, E.F. Da complementaridade à dependência: espaço, tempo e gênero em comunidades "pesqueiras" do nordeste. Revista Brasileira de Ciências Sociais, v.07, n.18, p.41-61, fev/mai., 1992. 